\title{
Static Electricity Rules for Plant Safety
}

\section{Report}

Author(s):

Expert Commission for Safety in the Swiss Chemical Industry (ESCIS)

Publication date:

2005-01

Permanent link:

https://doi.org/10.3929/ethz-b-000354478

\section{Rights / license:}

In Copyright - Non-Commercial Use Permitted

\section{Originally published in:}

ESCIS Safety Series 2 


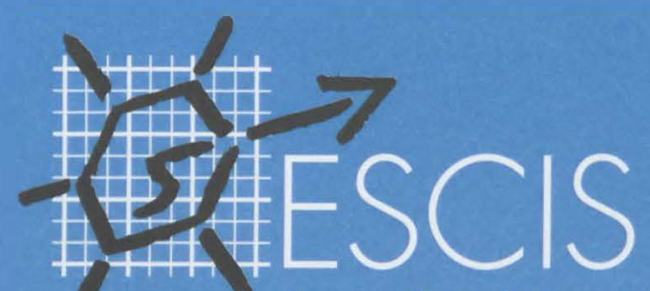

Expert Commission

for Safety in the Swiss Chemical Industry

\section{Safety}

Series

\section{Static Electricity}

\section{Rules for Plant Safety}

Booklet 22005

Revised 2nd edition 

To guarantee a sufficient degree of safety in chemical production, it is today increasingly necessary to perform systematic risk analyses which embrace the following operational steps:

- Compilation and procurement of information and data

- Analysis of the processes and work routines to determine the risks

- Evaluation of the risks according to the probability and consequences of possible incidents

- Determination of measures necessary to lessen the risks

- Evaluation of the risks remaining after implementation of the measures.

Risk analyses must encompass all possible critical areas. These can be outlined as follows:

- Chemicals

- Chemical reactions, physical processes

- Energy requirements

- Plants, apparatus, technical working aids

- Personnel, organization.

Further information is contained in ESCIS Booklet 4, "Introduction to Risk Analysis"

The present publication is a contribution to substantialIy lessening the risks arising from static electricity. The main emphasis is on describing practical measures which should be implemented with equipment and during operations in the chemical plant: from these descriptions, plant management should be able to derive concrete precautionary measures for any particular case. In cases where these rules do not provide satisfactory information, the aid of a specialist must be enlisted to determine appropriate precautions for the specific case, and to avoid measures which are unnecessary.

\section{Notes to the third German edition (1989)}

Following publication of the second German edition in 1984, an accumulation of experience and new knowledge led to first and second revisions of individual pages in July 1986 and January 1988 respectively. These revisions, as well as further new knowledge, have been integrated into the third German edition in 1989. Relative to the second German edition of 1984 , the amendments relate mainly to the following topics:

- Permitted containers for flammable liquids (especially conductive containers with an insulating lining)

- Handling of powdery solids with extremely low minimum ignition energy

- Charging highly insulating plastic granulates into silos and containers

- Use of flexible bulk containers ("big bags ") for powdery solids

- Permitted non-conductive plastic pipelines carrying dusts

- Testing the conductivity of filter fabrics

- Testing the breakdown voltage of insulating layers and walls

- Occurrence of cone discharges

- Bibliography

\section{Note to the fourth German edition (1997)}

Reprinting of the third German edition (1989) without revision.

\section{Preface to the second English edition (2005)}

This second English edition is a translation of the fourth German edition of 1997, which with a few amendments is a reprint of the third German edition of 1989.

The most important amendments which have been made in this second English edition of 2005 relate to

- Limit values for flow velocities of liquids

- Grounding of metal flanges on glass pipelines

- Permissibility of different types of package for flammable liquids and combustible dusts

- Sample taking, etc.

- Filling of dusts (cone discharges)

- Charging powders into solvents

- Filling and emptying FIBCs

- Bibliography

and are a consequence of adaptation to new international directives and standards. 
ANNEX A: Measurements in connection with static electricity

ANNEX B: Fundamentals

ANNEX C: Permissibility of different types of package for flammable liquids and combustible dusts 


\section{Practical section}

1. THE OCCURRENCE OF ELECTROSTATIC CHARGES IN PLANT OPERATIONS

2. WORKING WITH FLAMMABLE LIQUIDS

2.1 General (critical properties of flammable liquids) 6

2.1.1 Formation of explosive vapor/air mixtures 6

2.1.2 Electrostatic chargeability of liquids 6

2.1.2.1 Liquids with low and middle conductivity 6

2.1.2.2 Liquids with high conductivity . 6

2.1.2.3 Non-homogeneous liquids 6

2.1.3 Improving the electrical conductivity of flammable liquids
by means of additives

2.2 Practical examples, measures 7

2.2.1 Transfer of electrostatically chargeable liquids through
pipelines and hoses

2.2.2 Charging or emptying of drums and small containers by gravity 9

2.2.3 Transportation and transfer of chargeable liquids
by means of drum pumps

2.2.4 Charging of agitator vessels with flammable and
chargeable liquids

2.2.5 Operations at the open access port of a filled agitator vessel $\quad 10$

2.2.6 Charging of large glass vessels (measuring, feeding,

2.2.7 Loading and unloading of road and rail tankers (chargeable liquids) 11

2.2.8 Permissibility of various types of container for flammable liquids at temperatures lower than $5{ }^{\circ} \mathrm{C}$ under the flash point (closed cup) of the liquid

2.2.9 Transfer and filtration of chargeable suspensions on Nutsch filters and centrifuges at temperatures higher than $5{ }^{\circ} \mathrm{C}$ under the flash point

3. HANDLING OF SOLIDS IN POWDER FORM

3.1 General 13

3.1.1 Electrostatic charging and dust explosion hazards 13

3.1.2 The phenomenon of "hybrid mixtures" 13

3.2 Practical examples, measures 13

3.2.1 Handling of powders without flammable gases/vapors 13

3.2.2 Handling of powders with flammable gases/vapors 14

3.2.2.1 Closed charging of solids into an inerted apparatus $\quad 14$

3.2.2.2 "Open" charging of powders into flammable liquids or "open" charging of powders containing flammable liquids into an empty vessel when an inert atmosphere cannot be maintained

3.2.2.3 Discharging solids that contain flammable liquids from $\begin{array}{ll}\text { Nutsch filters, centrifuges and other filtration apparatus } & 16\end{array}$

3.2.2.4 Charging and emptying of drums and other containers 17

3.2.3 Special problems specific to certain types of equipment 17

3.2.3.1 Entrainment of electrostatic charges 17

3.2.3.2 Filling and emptying flexible intermediate bulk containers
("big bags")

3.2.3.3 Charging of powders into large containers (silos) 19

$\begin{array}{ll}\text { 3.2.3.4 Spray drying, fluid bed drying } & 19\end{array}$ 
3.2.3.5 Dust-carrying pipelines (ventilation ducts, blow-off pipelines on containers, dust-extraction pipelines, pneumatic conveyors) 19

3.2.3.6 Dust filters

4. MOVING PARTS ON MACHINES AND APPARATUS 20

5. THE HUMAN BODY AS A CARRIER OF ELECTROSTATIC CHARGES 21

6. HINTS FOR PLANNING AND CONSTRUCTION 21

$\begin{array}{lll}6.1 & \text { Buildings } & 21\end{array}$

$\begin{array}{lll}6.2 & \text { Floors } & 21\end{array}$

6.3 Atmospheric humidity 21

6.4 Suggested values for surface resistance and resistance to ground 22

6.5 Important practical rules 22

6.6 Specifications for fixed ground connections 22

6.7 Grounding connection of metal parts on glass and plastic pipelines with diameter $\geq \mathbf{5 0} \mathbf{~ m m} 23$ 


\section{The occurrence of electrostatic charges in plant operations}

The most common occurrences of static charges in plant operations are on the surfaces of solid bodies, powdery solid substances, and liquids. There is a distinction between electrical conductors - for example metals, aqueous solutions - and non-conductors or insulators - for example plastics, certain organic liquids. Electrically charged particles (electrons) on or in a conductor can move, whereas in an insulator they are fixed in position. If a surface has an excess or deficit of charged particles, it is said to be charged.

If two uncharged (neutral) surfaces, of which at least one is non-conductive, are brought into intensive contact and then rapidly separated from each other again, charged particles pass from one surface to the other and are unable to return sufficiently rapidly when the separation process takes place. One of the surfaces now has a deficit, and the other surface a surplus, of charged particles. Both surfaces are charged.

Typical occurrences of electrostatic charges (Fig. 1): A non-conductive liquid flows out of a metal pipe (separation effect). The liquid is charged, excess charges on the metal pipe leak to ground via the ground conductor.

Powder pours out of a plastic bag (separation effect). The powder and bag, as well as the dust cloud, are charged. Charges dissipate rather slowly (Fig. 2).

Transfer of non-conductive liquid or powder in glass or plastic pipe (sep-

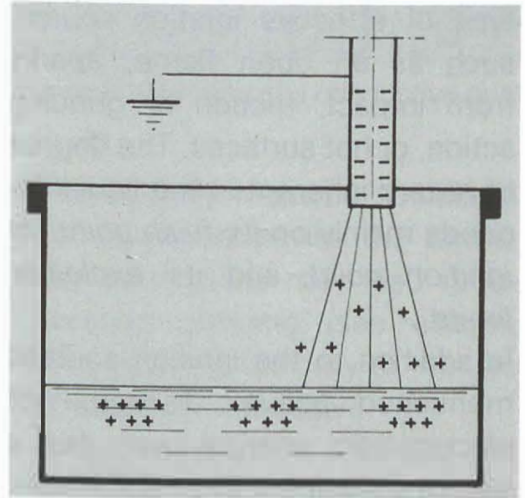

Figure 1: A non-conductive liquid flows out of a metal pipe

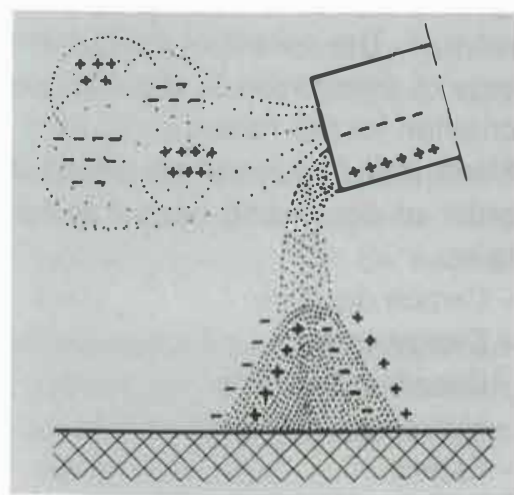

Figure 2: Powder pours out of a plastic bag

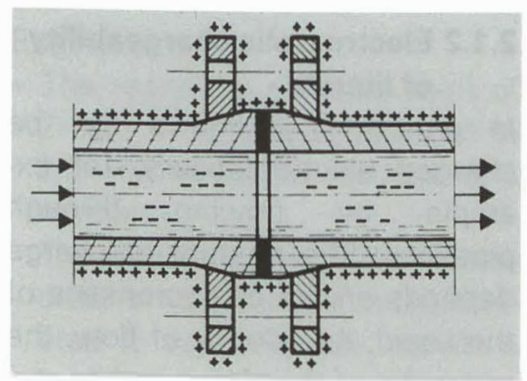

Figure 3: Transfer of a non-conductive substance in a glass pipe

aration effect in wall zone). Pipe, flanges, and contents are charged. Charge leakage is slow (Fig. 3 ).

Plastic or paper film is unwound (separation effect). The film and the roll are charged. Charge leakage is slow (Fig. 4).

Liquid is atomized through a metal nozzle (separation effect when

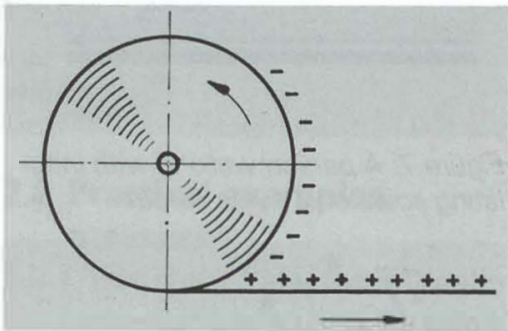

Figure 4: Plastic or paper film is unwound

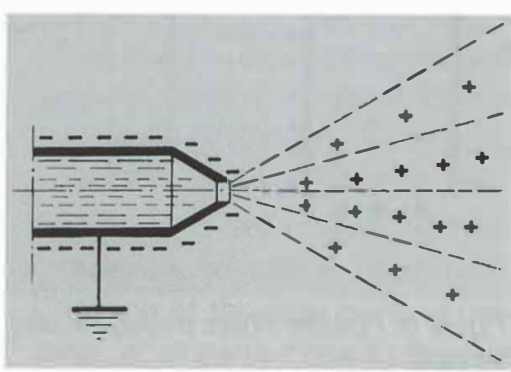

Figure 5: Liquid is atomized through a metal nozzle

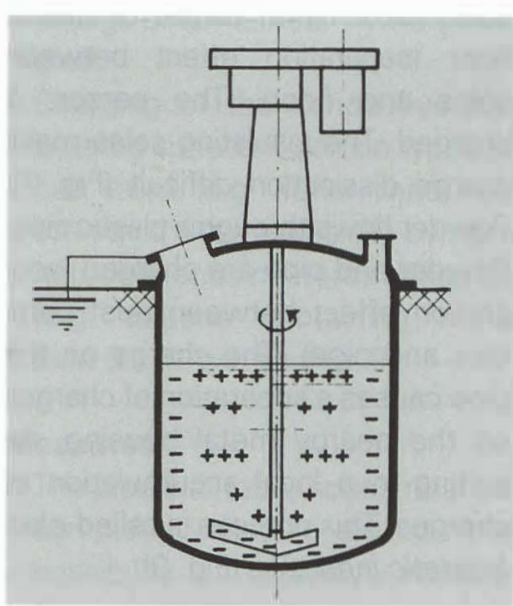

Figure 6: Stirring a non-conductive liquid in a vessel

droplets are formed). The liquid droplets and the nozzle are charged. The excess charge on the metal nozzle is dissipated via the grounding conductor (Fig. 5).

Agitating a non-conductive liquid in a vessel (separation effect on the vessel wall). The liquid, the agitator, and the vessel are charged. The charges on the vessel and on the agitator leak to ground (Fig. 6). 


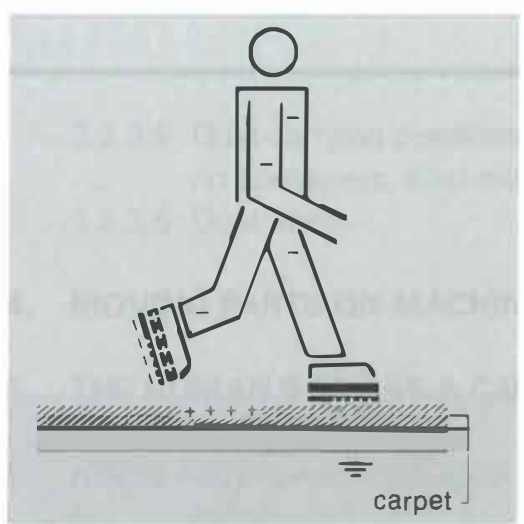

Figure 7: A person walking with insulating soles on a nylon carpet

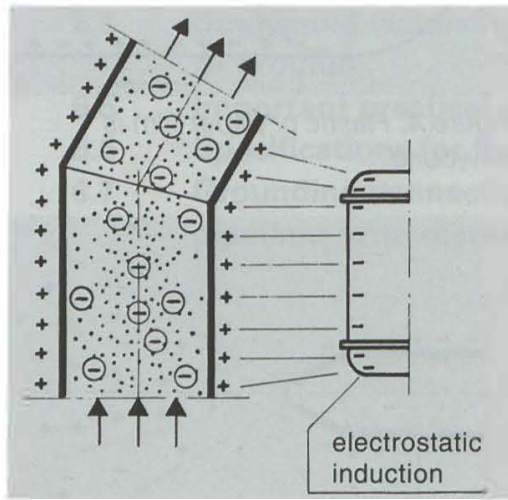

Figure 8: Powder flows through a plastic pipe

A person walking with insulating soles on a nylon carpet or plastic floor (separation effect between soles and floor). The person is charged. The insulating soles make charge dissipation difficult (Fig. 7). Powder flows through a plastic pipe. Powder and pipe are charged (separation effect between dust particles and pipe). The charge on the pipe causes a separation of charges on the nearby metal housing, resulting in a local accumulation of charges. This process is called electrostatic induction (Fig. 8).

\section{Working with flammable liquids}

\subsection{General (critical proper- ties of flammable liquids)}

When handling flammable liquids, there are basically two hazards to be considered, depending on the properties of the flammable liquid: - Formation of explosive vapor/air mixtures
- Electrostatic chargeability of liquids.

\subsubsection{Formation of explosive vapor/air mixtures}

Depending on their temperature and flash point, flammable liquids can form explosive vapor/air mixtures which can be ignited by any type of effective ignition source, such as an open flame, sparks from impact, friction or grinding action, or hot surfaces. The degree of hazard inherent in the liquid depends mainly on its flash point, its ignition point, and its explosion limits.

In addition to the ignition sources mentioned above, discharge of electrostatic charges can be a source of ignition. Even discharges caused by shaking an empty plastic bag may be of sufficient energy to ignite a highly flammable vapor/air mixture. The minimum ignition energy of the mixture is the decisive criterion for this hazard.

Flammable liquids can be ranked in order of decreasing hazard as follows:

- Carbon disulfide

- Diethyl ether

- Gasoline, Benzene

- Hydrocarbons

- Esters

- Lower ketones and alcohols

- Chlorinated hydrocarbons.

\subsubsection{Electrostatic chargeability of liquids}

In principle, all liquids can be charged electrostatically, for example by flowing through pipelines. The amount of charge depends on the characteristics of the liquid, its velocity of flow, the geometry of the piping and its material properties. Liquids with low or medium conductivity will be charged independently from the properties of the pipe walls. Liquids with high conductivity will be charged only if the pipe wall is non-conductive and the liquid is not grounded.

Since liquids of low conductivity charge themselves more strongly than those with high conductivity, the liquids are divided as follows regarding their conductivity $\gamma$ :

- Low conductivity

$$
\gamma \leq 5 \cdot 10^{-11} \Omega^{-1} \cdot \mathrm{m}^{-1}
$$

$\left(2 \cdot 10^{10} \Omega \cdot \mathrm{m}\right)$

- Medium conductivity

$5 \cdot 10^{-11} \Omega^{-1} \cdot \mathrm{m}^{-1}$

$<\gamma \leq 10^{-9} \Omega^{-1} \cdot \mathrm{m}^{-1}\left(1 \cdot 10^{9} \Omega \cdot \mathrm{m}\right)$

- High conductivity $10^{-9} \Omega^{-1} \cdot \mathrm{m}^{-1}<\gamma$

The tables 1 and 2, pages 6 and 7 . provide an overview of the resistivity (reciprocal of conductivity) of certain solvents in common use in chemical plants.

\subsubsection{Liquids with low and medium conductivity}

In this category we find aliphatic and aromatic hydrocarbons, ethers, esters of higher acids, $C_{1}$ derivatives.

Table 1. Liquids with low and medium conductivity $\left(\rho_{D}>10^{9} \Omega \cdot \mathrm{m}\right)$

$\begin{array}{lr}\text { Liquid } & \text { Resistivity } \\ \text { Carbon disulfide } & 10^{16} \Omega \cdot \mathrm{m} \\ \text { Carbon tetrachloride } & 10^{15} \Omega \cdot \mathrm{m} \\ \text { Diesel oil } & 10^{13} \Omega \cdot \mathrm{m} \\ \text { Gasoline } & \\ \text { Cyclohexane } & \\ \text { Benzene, toluene, xylene } \\ \text { Mesitylene } \\ \text { Diethyl ether } \\ \begin{array}{ll}\text { 1,4-dioxane } & 10^{12} \Omega \cdot \mathrm{m} \\ \text { Anisole } & 10^{11} \Omega \cdot \mathrm{m} \\ \text { Stearic acid dibutyl ester } & 10^{10} \Omega \cdot \mathrm{m}\end{array}\end{array}$

\subsubsection{Liquids with high conductivity}

Examples of this category are hydrocarbons with "polar" groups such as alcohols, aldehydes, ketones, acids, esters, nitriles, amides, amines, nitro compounds (see Table 2, page 7).

\subsubsection{Non-homogeneous liquids}

The tendency to accumulate static charges may be greatly increased if the liquid contains an immiscible component or a suspended solid.

Examples are:

- the suspension of solids in white spirit,

- small quantities of water in kerosene. 
Table 2. Liquids* with high conductivity $\left(\rho_{D}<10^{9} \Omega \cdot m\right)$

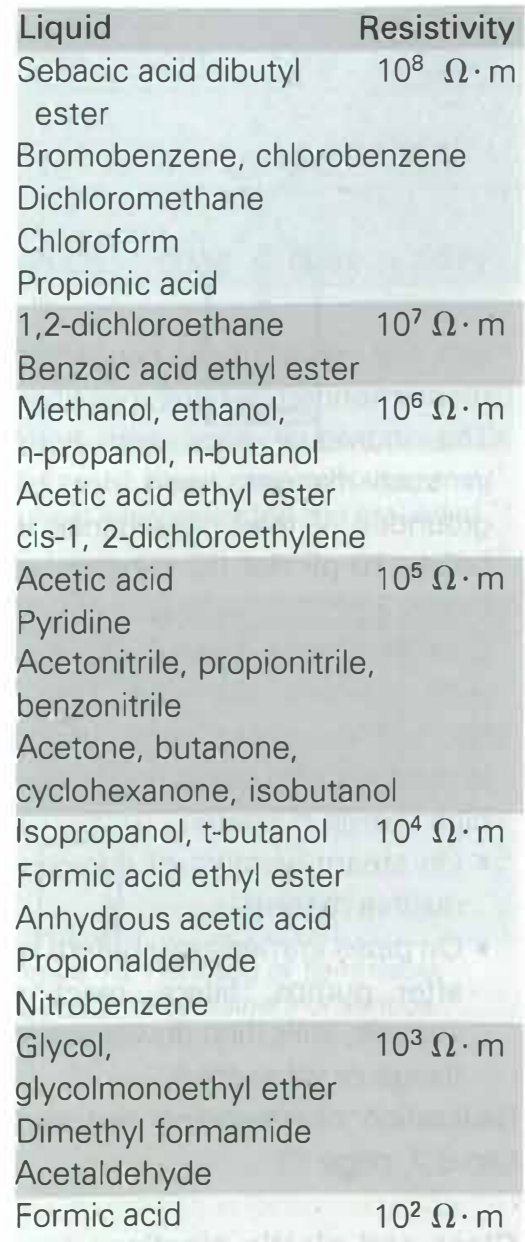

\footnotetext{
* NB: All values stated refer to pure liquids and are rounded to the nearest power of 10. Exact values will be found in [2].
}

During crystallization processes in liquids with low conductivity, local formation of extremely high charges is possible. Crystallization processes in flammable liquids with low conductivity should therefore always be performed under inert atmosphere.

\subsubsection{Improving the electrical conductivity of flammable liquids by means of additives}

Considerable charging of liquids during transfer, transit, or other operations must be expected if their resistivity exceeds $10^{9} \Omega \cdot \mathrm{m}$. By the addition of small quantities of highly polar solvents, special chemicals or water, the resistivity can be appreciably reduced. During such operations, the following must be borne in mind:

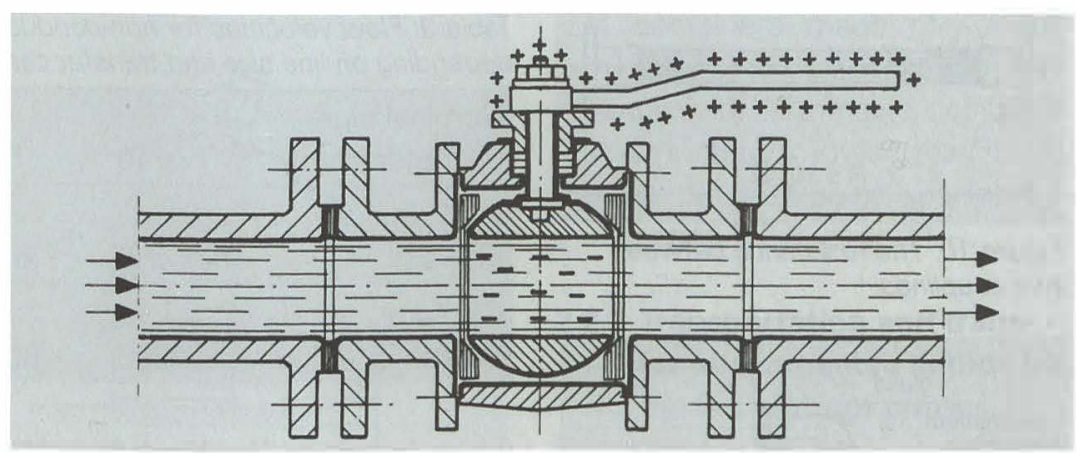

Figure 9: Charging of a conductive but isolated ball valve

- The additive must be soluble in the liquid, otherwise the formation of droplets may lead to increased charging (see above). This applies especially to the use of water as an additive.

- When clarification is carried out with filter aids, additives are often removed. The same applies to extraction operations, and to washing processes with acid or alkaline media. If necessary, further quantities of the additives must be added.

- In suspensions, the solid material can adsorb the additive, and hence its effect will be neutralized.

- The effectiveness of antistatic additives can sometimes diminish, or completely disappear, owing to aging processes.

The effectiveness of the additives must be tested by measurement.

\section{Examples:}

- The resistivity of white spirit of $2 \cdot 10^{11} \Omega \cdot \mathrm{m}$ can be reduced to $2.5 \cdot 10^{9} \Omega \cdot \mathrm{m}$ by adding $5 \%$ methanol.

- The resistivity of gasoline is in the order of $10^{13} \Omega \cdot \mathrm{m}$. It can be lowered to approximately $10^{8} \Omega \cdot \mathrm{m}$ by adding $1-2 \mathrm{~g}$ per $\mathrm{m}^{3}$ of an antistatic additive (e.g. Stadis 450).

A special situation exists when a conductive liquid flows through a pipe made of insulating plastic material. If the liquid cannot wet the plastic surface (e.g. water on Teflon), individual columns or droplets of the liquid which are not in contact with a grounded part may become charged.

\subsection{Practical examples, measures}

\subsubsection{Transfer of electrostatically} chargeable liquids through pipelines and hoses

\section{Hazards:}

- Charging of the liquid when it flows along walls (pipes, agitated vessels), when it collides with fixed parts or with liquid surfaces, when it is sprayed, when it passes through filters, especially microfilters (pore size $<10 \mu \mathrm{m}$ ).

- Charging of the pipe or hose material, or of parts close to the line or hose (by induction). Sparking between metal parts - e.g. hose fittings or containers - when handled.

- Charging of the conductive but isolated sphere in certain types of ball valve (e.g. Teflon-lined), by the liquid flow especially by nonhomogeneous mixtures of liquids (e.g. toluene containing more than $0.1 \%$ water) (Fig. 9).

\section{Measures:}

- The pipeline (tube, hose) must be completely filled to exclude the possibility of explosive mixture formation within the pipe.

- Keep the liquids pure. Particles of dust or droplets of water are charge carriers.

- If the use of microfilters is envisaged, special measures may be required: a specialist should be consulted.

- Flow velocities must be kept low. For only partially filled pipelines or pipes which discharge into containers, the flow velocity must be limited as follows (irrespective of the pipe material): 


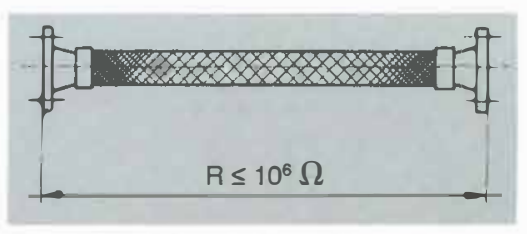

Figure 10: The resistance between two couplings

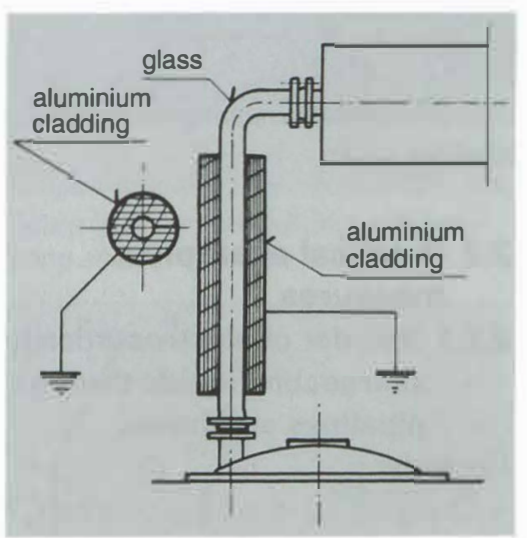

Figure 11: Grounding of metallic jackets on insulating material

- for chargeable esters: max. $10 \mathrm{~m} \cdot \mathrm{s}^{-1}$

- for mineral oil products (e.g. gasoline, kerosene, paraffin, aviation fuel) and for other chargeable liquids (excluding carbon disulfide and ether), depending on line size (see Table 3). These values are derived from investigations with hydrocarbon fuels and metal pipes. Since no specific data are available for non-conductive pipes, it is recommended to adhere to the values shown in Table 3.

If these flow velocities are adhered to, no hazardous charges will be generated within homogeneous liquids. But when suspensions of crystals in non-conductive liquids are conveyed, the formation of hazardous charges must always be taken into account, even at velocities below $1 \mathrm{~m} \cdot \mathrm{s}^{-1}$.

- For ether and carbon disulfide in pipelines with a diameter up to $25 \mathrm{~mm}$ : max. $1 \mathrm{~m} \cdot \mathrm{s}^{-1}$; larger pipes require lower velocities.

- Rule of thumb for all homogeneous liquids (except ether and carbon disulfide) and all pipelines: at flow velocities below $1 \mathrm{~m} \cdot \mathrm{s}^{-1}$, no dangerous charges will be generated.

Selection of suitable hoses:

It is known from experience that

Table 3: Flow velocities for non-conductive homogeneous liquids $\left(\rho_{D}>10^{9} \Omega \cdot m\right.$ ) depending on line size and transfer capacity.

\begin{tabular}{lrrrrrr}
\hline $\begin{array}{l}\text { Nominal pipe } \\
\text { diameter [mm] }\end{array}$ & $\leq 40$ & 50 & 80 & 100 & 200 & 300 \\
\hline $\begin{array}{l}\text { Flow velocity } \\
{\left[\mathrm{m} \cdot \mathrm{s}^{-1}\right]}\end{array}$ & max. 7.0 & 6.0 & 3.6 & 3.0 & 1.8 & 1.2 \\
\hline $\begin{array}{l}\text { Capacity } \\
{\left[1 \cdot \text { min }^{-1}\right]}\end{array}$ & $\leq 500$ & 800 & 1100 & 1600 & 3500 & 5000 \\
\hline
\end{tabular}

when hoses or flexible tubes are used, grounding of containers which are often mobile - is not always achieved with the desired degree of reliability. Therefore, for velocities exceeding $1 \mathrm{~m} \cdot \mathrm{s}^{-1}$, only the following hoses are acceptable:

- Hoses made of conductive material.

- Hoses made of non-conductive material with embedded fine wire mesh. The mesh must be connected conductively to the metal hangers or the hose coupling.

- Metal hoses with liners: the metal sheath and flanges or couplings must be conductively interconnected.

For all three types of hose the following criteria must be fullfilled:

- The electrical resistance between the two couplings must not be greater than $10^{6} \Omega$. This resistance must be measured at regular intervals (Fig. 10).

- Use ball valves with grounded metal sphere.

- Ground metal pipelines. In many cases, the metal elements (supports, clamps) provide adequate grounding. In the case of painted or enameled pipes, this must be verified by measurement; for pipelines with flanges, each individual pipe element must be measured.

- Do not use plastic pipelines with nominal diameter greater than $30 \mathrm{~mm}$ unless they have a conductive liner.

- On glass pipelines, large isolated metal parts such as flanges with a nominal diameter $\geq 50 \mathrm{~mm}$, valves, flaps, dampers, and also metallic jackets on insulating material, reinforcing metal plates, etc. must be grounded (Fig. 11). To keep expenditure within rea- son, the use of plastic hangers is recommended where possible. The individual nuts and bolts in such flanges need not be grounded, if their capacitance is below $10 \mathrm{pF}$ (for IIC substances below $3 \mathrm{pF}$ ).

Smaller flanges, valves, etc. (i.e. with nominal diameter below $50 \mathrm{~mm}$ ) must also be grounded in the following cases (extremely high charge build-up):

- On steam ejectors of non-conductive material

- On pipes immediately before or after pumps, filters, reaction vessels, stills (first downstream flange or valve only)

Realization of grounding see section 6.7, page 23.

\section{Glass and plastic pipelines can- not be grounded.}

Grounding wires must be wound loosely around or laid parallel to a non-conductive line for connection and grounding of flanges. A grounding wire should not be inserted in a pipe. If the wire breaks, sparking is possible (Fig. 12, 13).

\section{Grounding of flanges:}

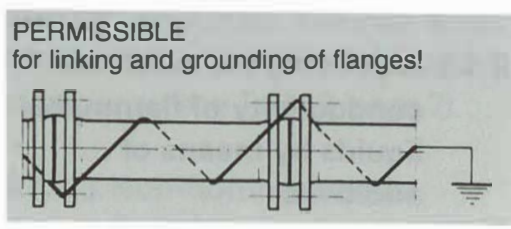

Figure 12: Wire wound around a nonconductive line for grounding flanges (correct)

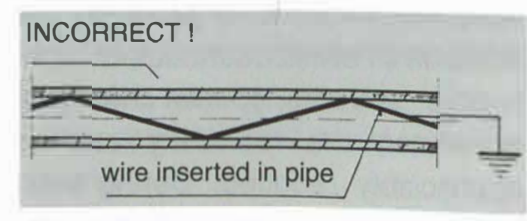

Figure 13: Wire inserted in pipe for grounding (incorrect) 


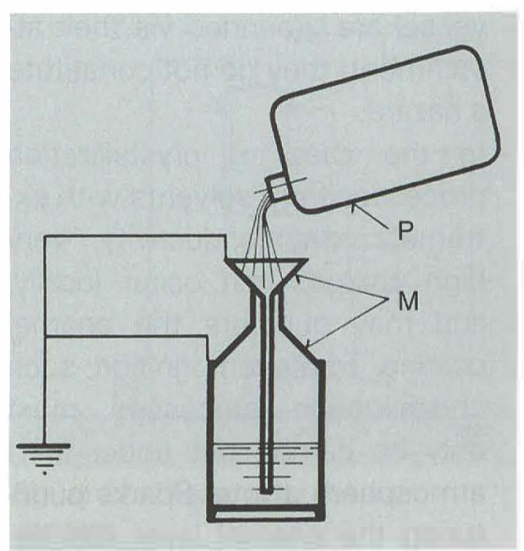

Figure 14: Conductive container and funnel interconnected and grounded

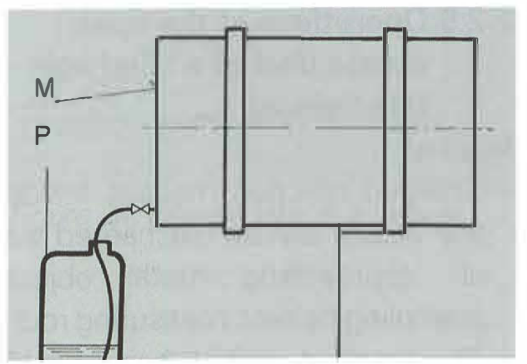

Figure 15: Handling of flammable liquids with containers of various materials

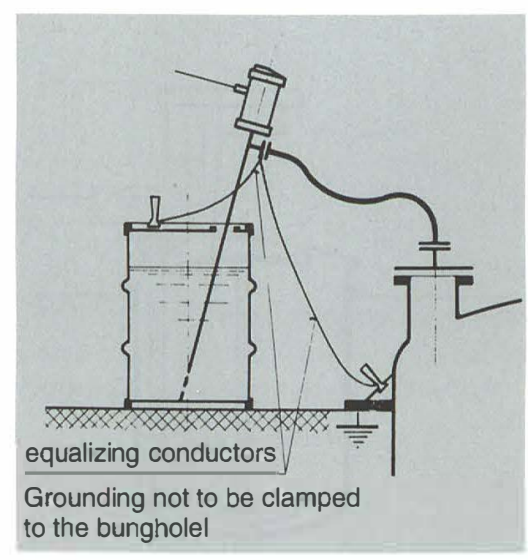

Figure 16: Grounding connections between pump and containers

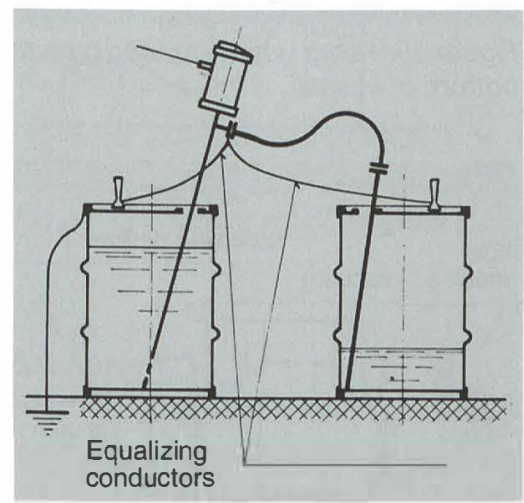

Figure 17: Permanently fixed conductors to the drum pump

water and toluene) are present in a non-conductive container, and one of the liquids is conductive, this one can form an isolated, conductive, and thus chargeable, layer.

- On non-conductive surfaces e.g. the inner surface of a nonconductive plastic container high charges caused by friction and separation processes may accumulate. When a conductive object is approached, corona or brush discharges are possible.

- Liquids with a resistivity > $10^{9}$ $\Omega \cdot m$ may become charged. A dangerous potential builds up on the surface of the liquid. When a conductive object (funnel, agitator, hose) is approached, incendive brush discharges may occur.

- Spark discharges can occur on conductive containers, e.g. between funnel and container or between operator and container.

- If two immiscible liquids (e.g.

\section{Measures:}

- Take the filling pipe, tube or funnel right down to the bottom of the vessel to avoid bubble formation, eddying and splashing (Fig. 14).

- Conductive containers, funnels, nozzles and tubes must be interconnected and grounded (Fig. 14 and 15).

- Ground operating personnel by means of conductive shoes and conductive floor.

- Liquids containing an immiscible conductive component should be poured into conductive containers only.

- Information on the permissibility of containers made of various materials, and concerning the handling of flammable liquids at a temperature lower than $5{ }^{\circ} \mathrm{C}$ under the flash point: see Table 4 in section 2.2.8, page 11.

\subsubsection{Transportation and trans- fer of chargeable liquids by means of drum pumps}

Hazard:

- Fluid flow in the connecting line and turbulence in the pump can lead to charging of the liquid and of the pipe or tube material. Sparking is possible between metal parts, e.g. between the drum pump and the drum, especially when the pump is being inserted or removed.

Measures:

- Connect the drum pump conductively to both the container being emptied and the one being filled, and ground it. The connections should not be clamped directly onto the drum inlet or access port, as this is the most likely place to find flammable vapors (Fig. 16).

- The two equalizing conductors are best fixed permanently to the drum pump so that the necessity for interconnection and grounding is immediately apparent whenever the pump is used (Fig. 17).

\subsubsection{Charging of agitator ves- sels with flammable and chargeable liquids}

Hazard:

- Charging of the liquid by turbulence when flowing in under pressure, by whirling up and spraying, especially if inert gas or air flows in at the end of a pneumatic filling or transfer process. Brush discharges can occur between the surface of the liquid and conductive internal fittings.

\section{Measures:}

- Fill slowly, do not exceed velocities given in Table 3, section 2.2.1, page 8; if possible, fill vessel via bottom valve or extend fill- 


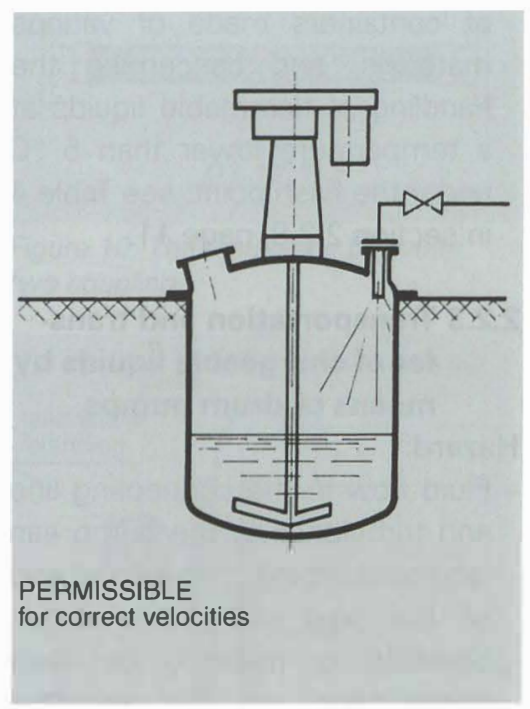

Figure 18: Filling-process with low velocity

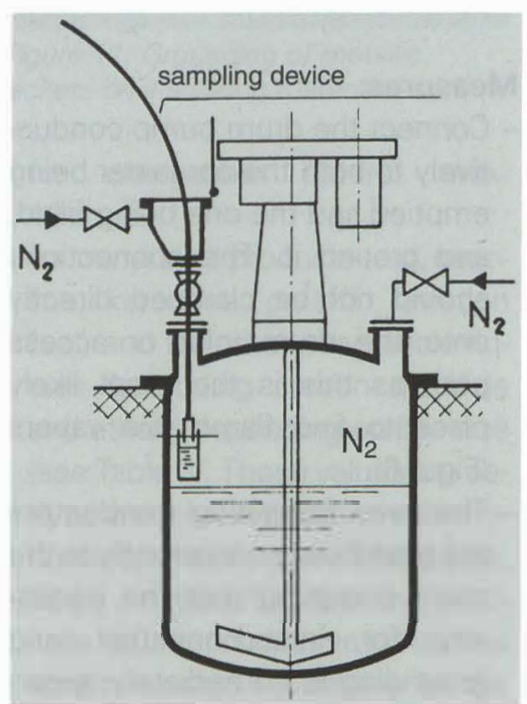

Figure 20: Sampling device on closed vessel (inerted)

ing pipe downward to bottom of vessel (Fig. 18 and 19).

- An alternative is to suck in the liquid with "closed vacuum"1 (to prevent environmental pollution), or

- purge the vessel with inert gas: as a rule, nitrogen should be used. (Inerting with $\mathrm{CO}_{2}$ gas can be hazardous: $\mathrm{CO}_{2}$ flowing in under pressure or in the liquid state can form highly charged dry ice crystals, making brush discharges possible.)

Evacuate the vessel, then close the connection to the vacuum pump before opening the filling line. This ensures that no vapors will be aspirated by the vacuum pump.

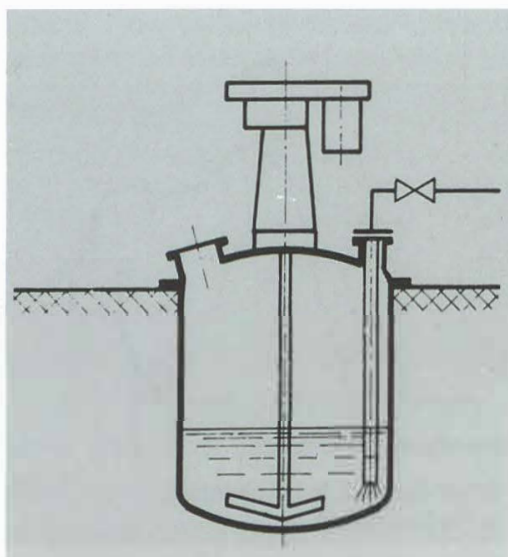

CORRECT! favorable from an electrostatic point of view. Caution: if liquid is discharged to another vessel backflow through dip pipe must be prevented

Figure 19: Filling with extended pipe to bottom of vessel

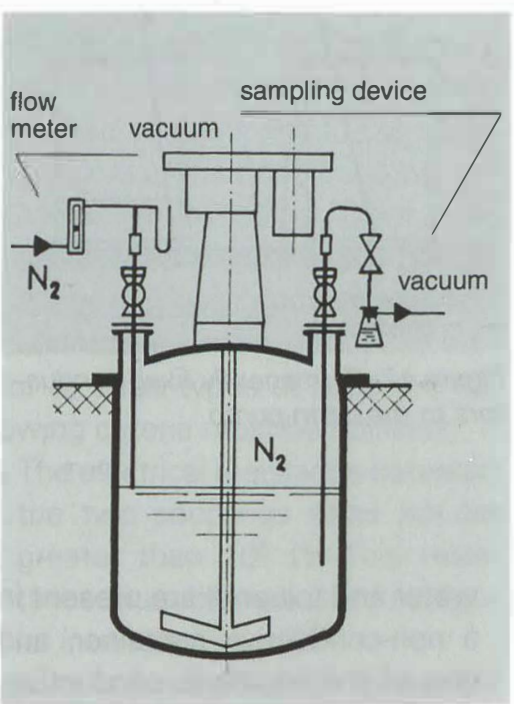

Figure 21: Sampling device on closed vessel (vacuum and inerted)

Take care when discharging a batch to another vessel with compressed air: "blowing off" at the end must be avoided. If this is not possible, nitrogen must be used for purging and discharging.

\section{Special remarks concerning enameled vessels:}

- Since the whole of the inside of the vessel is enameled, excess charges can leak to ground only through the enamel coating. However, owing to the relative thinness and large area of the enamel coating, such charges dissipate fairly rapidly (in seconds to minutes).

- Tantalum plugs in the wall of a vessel are grounded via their attachment: they do not constitute a hazard.

- In the case of crystallization processes from solvents with extremely low conductivity, very high charges can occur locally, and may puncture the enamel coating. To prevent ignition, such crystallization processes must only be carried out under inert atmosphere. (Note: Sparks puncturing the enamel layer can destroy the enamel within a very short time.)

\subsubsection{Operations at the open access port of a filled agi- tator vessel}

\section{Hazard:}

- Charged reaction masses inside the vessel can be discharged via an approaching metal object (sampling beaker, measuring rod). The greatest ignition hazard is in the region of the access port, where solvent vapors mix with air. Discharges are also possible between the flange of the access port and a conductive object already in contact with the reaction mass.

\section{Measures:}

- Avoid operations at the open access port, use devices that permit sampling, $\mathrm{pH}$, and level checks on the closed vessel (Fig. 20 and 21 show two possible solutions).

- If operations at the open access port are unavoidable, the choice of the correct material for the sampling beaker is crucial. In case of sampling from a highly charged non-conductive liquid or suspension, a non-conductive sampling beaker on a non-conductive rod is recommended. The rod and the beaker should be kept as small as possible, and should not be wiped immediately before use. In all other cases, a conductive and grounded (metallic or conductive plastic) sampling beaker and rod are recommended. The same applies to gauge sticks. In case of uncertainty, expert advice is recommended. 


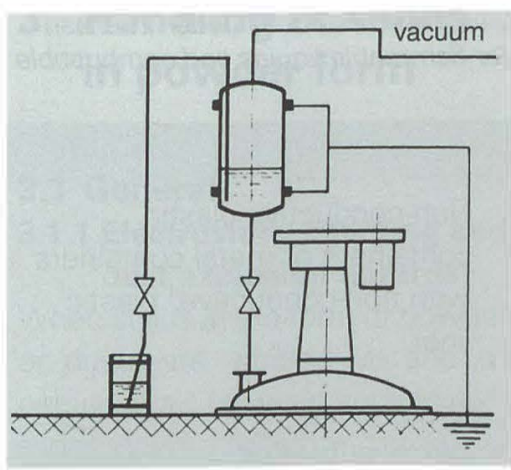

Figure 22: Charging by "closed vacuum"

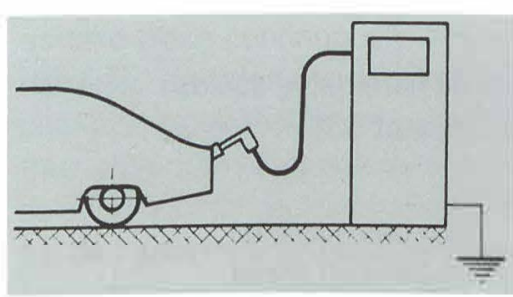

Figure 24: Filling a tank of a vehicle

Notes:

- Observe a stabilization period, i.e. after turning off the agitator and stopping the inflow of chemicals, wait 3 minutes before opening the access port.

- If a crystallization process is accompanied by pronounced charging, withdrawal of samples should be avoided during this phase of the process. If it is unavoidable, specialists should measure the charges generated, and the plant manager must issue special instructions for sampling.

- When withdrawing samples from a vessel which has not been inerted, open the relief venting of the vessel only just enough to prevent solvent vapors escaping into the room (so as to draw as little vapor as possible into the ventilation system).

- Each time the access port is opened, for however short a time, air (containing oxygen) enters the vessel. The atmosphere above the solvent, whether it consists of nitrogen or a mixture of vapor and air above the upper explosion limit, can thus become locally explosive.

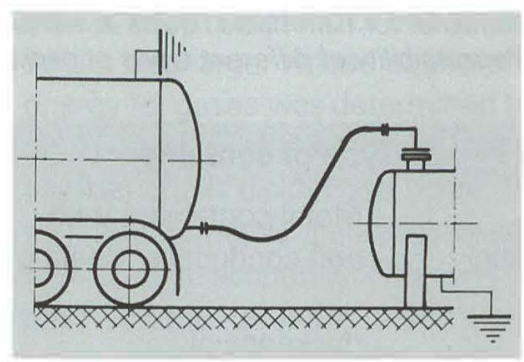

Figure 23: Unloading of a road tanker

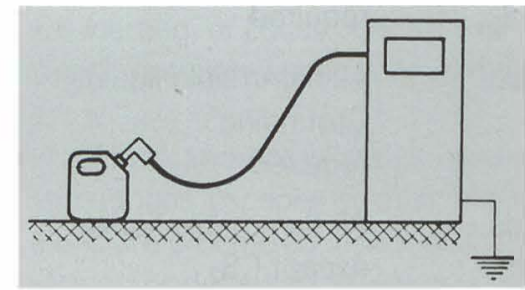

Figure 25: Filling a small container

\section{Exception:}

Inerting of small reaction vessels with open access port is possible by means of a special funnel; see section 3.2.2, page 14 .

\subsubsection{Charging of large glass vessels (measuring, feed- ing, separating vessels, etc.)}

Hazard:

- Charging of the liquid and of the vessel due to flow and whirling up. Discharge of sparks possible between conductive parts, e.g. between metal flange and operating personnel.

\section{Measures:}

- Grounding of metal flanges $\geq 50$ $\mathrm{mm}$ and

- inerting of glass vessel before charging

or

- charging at low velocities (see Table 3, page 8).

- Another alternative is charging by means of "closed vacuum"2 (Fig. 22).

Additional measures, if possible involve

- taking filling pipes right down to the bottom of the vessel. If PTFE pipes (polytetrafluoroethylene,
Teflon) are used, they should be of conductive grade and grounded.

Note:

Metal grounding rods in glass vessels have practically no effect.

\subsubsection{Loading and unloading of road and rail tankers (chargeable liquids)}

Hazard:

- Charging of the liquid due to flow, charging of the vehicle. The driver may be charged when leaving the cab. Sparks between conductive parts, e.g. between hose fittings and vehicle, or between driver and tank or vehicle.

\section{Measures:}

- Connect vehicle and tank with a grounded conductor (a loop chain alone is not sufficient) (Fig. 23).

- Use conductive hose material.

- Wear conductive shoes.

- The metal delivery nozzle is grounded via the gasoline hose, and must rest firmly on the filler pipe while the tank is being filled to ensure that the vehicle is also grounded (Fig. 24).

- When filling plastic cans, use only small ( $\leq 5$ I) plastic cans (Fig. 25). Charges accumulated in the liquid can leak away only very slowly when filling containers made of non-conductive material. However, no dangerous charges will accumulate on containers with a volume less than 5 liters, except for carbon disulfide (see 2.2.8). See also the section on improving the conductivity of liquids, 2.1.3, page 7 .

\subsubsection{Permissibility of various types of container for flammable liquids at tem- peratures lower than $5^{\circ} \mathrm{C}$ under the flash point (closed cup) of the liquid ${ }^{3}$ $\rightarrow$ see Table 4, page 12 .}

\footnotetext{
2 "closed vacuum": see explanation on page 10, footnote 1 . ${ }^{3}$ see footnote 3 , page 12 .
} 
Table 4: Permissibility of various types of container for flammable liquids at temperatures lower than $5^{\circ} \mathrm{C}$ under the flash point (closed cup) of the liquid ${ }^{3}$. (Permissibility of different types of package for flammable liquids and combustible dusts see Annex C, page 38.)

\begin{tabular}{|c|c|c|c|}
\hline & & Type of container & \\
\hline 10 & $\begin{array}{l}\text { Metal containers } \\
\text { (or conductive plastic) }\end{array}$ & $\begin{array}{l}\text { Metal containers with } \\
\text { non-conductive } 4 \text { coating } \\
\text { thickness of } \\
\text { coating } \leq 2 \mathrm{~mm}\end{array}$ & $\begin{array}{l}\text { Non-conductive plastic } \\
\text { containers or metal containers } \\
\text { with non-conductive }{ }^{4} \text { plastic } \\
\text { liner }\end{array}$ \\
\hline Volume in liters & permissible for: & permissible for: & permissible for: \\
\hline$V \leq 2$ & $\begin{array}{l}\text { All flammable liquids } \\
\text { Grounding not } \\
\text { required, except } \mathrm{CS}_{2}\end{array}$ & $\begin{array}{l}\text { All flammable liquids } \\
\text { Grounding not } \\
\text { required }\end{array}$ & All flammable liquids \\
\hline $2<V \leq 5$ & $\begin{array}{l}\text { All flammable liquids } \\
\text { Grounding } \\
\text { required }\end{array}$ & $\begin{array}{l}\text { All flammable liquids } \\
\text { Grounding } \\
\text { required }\end{array}$ & $\begin{array}{l}\text { All flammable liquids } \\
\text { except } \mathrm{CS}_{2}\end{array}$ \\
\hline $5<V \leq 250$ & $\begin{array}{l}\text { All flammable liquids } \\
\text { Grounding required }\end{array}$ & $\begin{array}{l}\text { All flammable liquids }{ }^{5} \\
\text { except } \mathrm{CS}_{2} \\
\text { Grounding required }\end{array}$ & $\begin{array}{l}\text { Not permissible } \\
\text { (enameled metal } \\
\text { containers are } \\
\text { permissible) }\end{array}$ \\
\hline$V>250$ & $\begin{array}{l}\text { All flammable liquids } \\
\text { Grounding } \\
\text { required }^{6}\end{array}$ & $\begin{array}{l}\text { All flammable liquids } 5 \\
\text { except } \mathrm{CS}_{2} \\
\text { Grounding required }\end{array}$ & $\begin{array}{l}\text { Not permissible } \\
\text { (enameled metal } \\
\text { containers are } \\
\text { permissible) }\end{array}$ \\
\hline
\end{tabular}

${ }^{3}$ At temperatures at least $5^{\circ} \mathrm{C}$ below the flash point, no explosive vapor/air mixtures will be formed. The margin of $5^{\circ} \mathrm{C}$ is intended to cover the scatter of flash point determinations. In addition, possible variations in product quality must be considered, they can cause flash point variations of several ${ }^{\circ} \mathrm{C}$

${ }^{4}$ See limits of surface resistance given in Annex A, 3.1, page 27.

${ }^{5}$ Conductive liquids must be grounded when being transferred (e.g. by immersion of a grounded tube)

${ }^{6}$ Special rules apply to large containers and fixed installations.

\subsubsection{Transfer and filtration of chargeable suspensions on Nutsch filters and centrifu- ges at temperatures higher than $5^{\circ} \mathrm{C}$ under the flash point $^{3}$}

Hazard:

- Generation of high charges during transfer of the suspension (internal friction) and especially during filtration or centrifuging (separation of liquid/solid phases) owing to intensive separation processes. In centrifuges, additional hazard caused by the high velocity of rotating parts close to internal fittings of the machine.

- Charging of the filter cake and of isolated conductive parts, e.g. metal nozzle on plastic tube. Discharges when a grounded con- ductive part is approached, or when the filter cloth is removed.

\section{Measures:}

- Use of closed apparatus with correct inerting is mandatory; grounding of all metal parts.

\section{Notes:}

- For discharge of solids still moist with solvent, see section 3.2.2, page 14.

- Charging of powdered solid carbon dioxide on a Nutsch filter prior to filtration is not a reliable inerting method. For correct inerting, the oxygen concentration in the inert gas outlet of the apparatus must be monitored continuously, or at least measured by frequent random checks.

- Whenever an inerted apparatus is opened, even if only for a very short time, air and hence oxygen will enter, and the atmosphere inside can become explosive. Therefore, when it is necessary to open inerted apparatus, operations and processes that could lead to ignition must only be carried out after the inert atmosphere has been restored and there can be no doubt that the oxygen concentration is again below the critical limit. 


\section{Handling of solids in powder form}

\subsection{General}

\subsubsection{Electrostatic charging and dust explosion hazards}

When solids in the form of powders or dusts are whirled up and dispersed in air, or when such material slides down chutes and pipelines, e.g. during grinding, sifting, mixing, and filling, or during pneumatic transportation, separation processes take place continuously. The individual particles may become charged independent of whether they arise from a conductive or insulating substance. Parts of apparatus and equipment which come into contact with the charged powder are then also charged.

When dispersed in air, most combustible solids such as powders or dusts are explosive under certain conditions. If they are handled as granules, flakes, or in coarse, crystalline form, a certain fraction of explosive fines will normally be present. Once an explosion of the fine dust has been initiated, the coarse dust that would normally not be explosive can also participate in the explosion reaction. According to previous experience and conceptions, dispersed combustible dusts can be ignited only by discharges of static electricity when these occur in the form of relatively powerful spark discharges, propagating brush discharges or cone discharges, but not by brush discharges or corona discharges.

According to the present state of knowledge, brush discharges cannot ignite pure dust/air mixtures even if the minimum ignition energy of the dust/air mixture is extremely low. The apparent contradiction that at a maximum of 3-4 $\mathrm{mJ}$ the equivalent energy ${ }^{7}$ of brush discharges determined with flammable gases is higher than the minimum ignition energy of individual dusts measured in the discharge circuit even with no induction can be explained as follows: In the presence of a dust cloud, brush discharges take on a different form. Instead of one single strong discharge, whose equivalent energy for gases was determined to be 3-4 $\mathrm{mJ}$, in a dust cloud many weaker brush discharges occur. In the case of highly insulating dusts where dust accumulations with a dust volume of more than $1 \mathrm{~m}^{3}$ occur, additional explosion protection measures beyond the measure "avoidance of effective ignition sources" may be required depending on the $\mathrm{MIE}_{\mathrm{OL}}{ }^{8}$ of the dust. Examples of such additional measures are inerting, or constructional explosion protection (explosion venting, etc.).

In plants and installations where substances capable of dust explosions are processed, a first dust explosion or deflagration which is not serious in itself may swirl up and ignite dust deposits (e.g. on pipelines, apparatus, supporting structures) and thereby cause a possibly much more serious secondary explosion.

\subsubsection{The phenomenon of "hybrid mixtures"}

Combustible dusts in the presence of solvent vapors in the air (socalled hybrid mixtures) can be explosive even when the concentration of the dust (or of the fines in coarse dust) and the solvent vapor are below the lower explosive limits for the individual components. Further, the presence of flammable gases or vapors increases the ignitability of airborne combustible dust, i.e. the minimum ignition energy of such mixtures is lower than that of the pure dust dispersion and can decrease to that of the solvent vapor (see Annex B, section 2.2, page 33). Ignition of hybrid mixtures by brush discharges cannot be ruled out.

\subsection{Practical examples, measures}

\subsubsection{Handling of powders without flammable gases/vapors}

For the handling of powders (charging and discharging, mixing, screening, vibratory conveying, etc.) in the absence of flammable gases or vapors, the following applies:

Hazard:

- On relatively large conductive parts that are not grounded, sufficient charge can accumulate to finally produce a spark. This can, under certain circumstances, ignite dispersed dust.

- Accumulation of highly insulating (resistivity $\geq 10^{10} \Omega \cdot \mathrm{m}$ ) powder in containers and silos may lead to cone discharges.

- Accumulation of highly insulating powder in a flexible intermediate bulk container ( $\mathrm{F} \mid \mathrm{BC})$ may lead to propagating brush discharges.

\section{Measures:}

- All conductive parts such as drum, funnel, chute, etc., must be grounded.

- For an assessment of the occurrence and incendivity of cone discharges, as well as the measures required of and against them, expert advice is recommended.

- To avoid propagating brush discharges the breakdown voltage of the FIBC fabrics must be less than $4 \mathrm{kV}$. This is the requirement for FIBC of Type B.

\section{Notes:}

- It should be noted that the use of containers with plastic liners is permitted. The construction material of drums, funnel, chute, discharge pipe, etc. is not restricted, provided the absence of flammable vapors or gases in the area can be assured and powder transport and handling occurs by gravity only (Fig. 26 and 27, page 14).

\footnotetext{
7 The equivalent energy (equivalent ignition energy) is that amount of energy which when converted into an electrical spark discharge under specified conditions has the same incendivity as the ignition source being characterized.

${ }^{8} \mathrm{MIE} \mathrm{EL}_{\mathrm{L}}$ : Minimum ignition energy determined with no induction in the discharge circuit.
} 


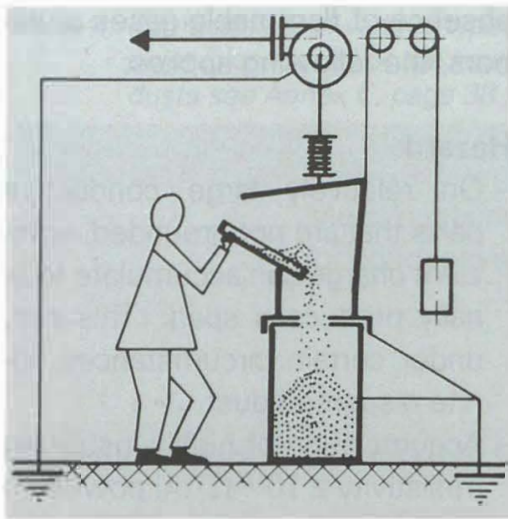

Figure 26: Handling of powder in plastic drum by gravity without flammable gases or vapors

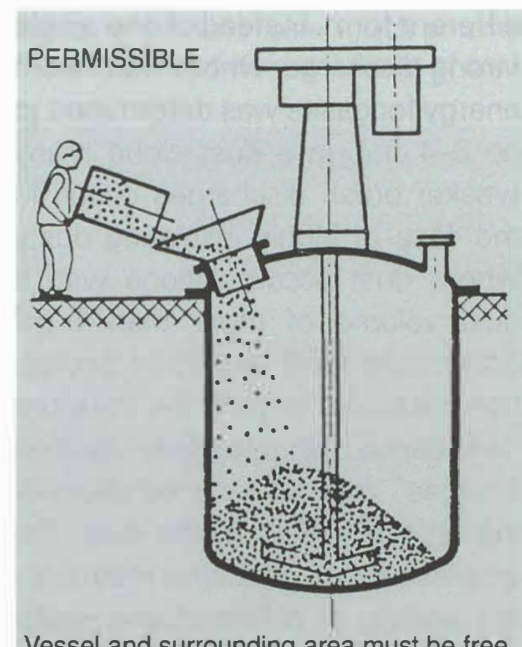

Vessel and surrounding area must be free from flammable vapors, gases and liquids

Figure 27: Handling of powder in a vessel by gravity without flammable gases or vapors

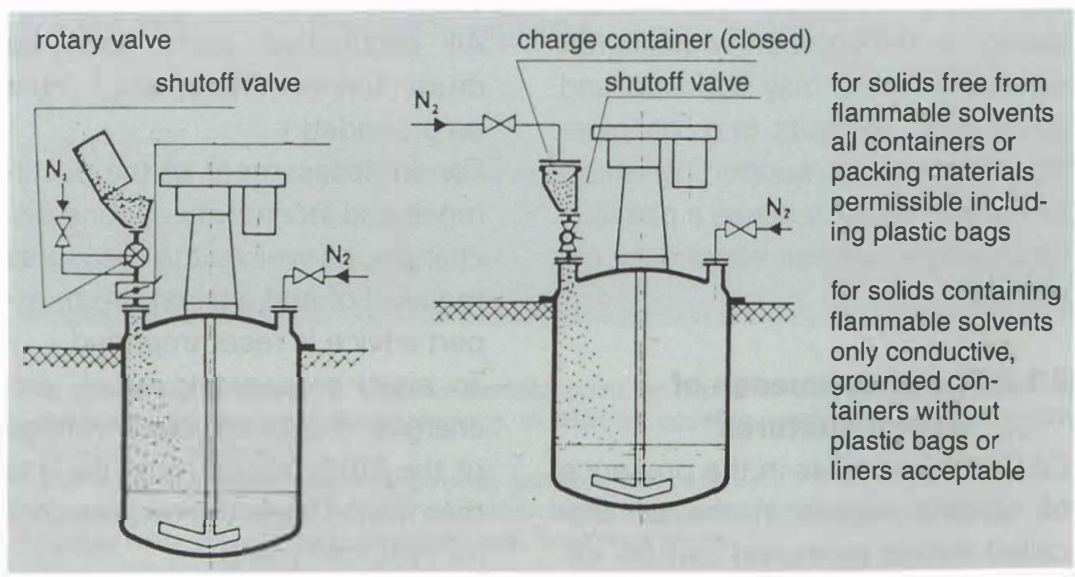

Figure 28: Charging powder containing flammable solvents through a rotary valve (inerted)

\subsubsection{Handling of powders with flammable gases/vapors}

For the handling of powders in the presence of flammable gases or vapors, e.g.

- for charging powders into flammable solvents,

- or handling of solids moistened with solvents ${ }^{9}$, the following applies:

\section{Hazard:}

- Owing to the movement of the material during charging or handling, separation processes take place continuously, and the pow-

\footnotetext{
${ }^{9}$ As a rule, powders containing less than 0.5 wt $\%$ flammable solvent can be considered solvent-free in such operations.
}

Figure 29: Charging powder containing flammable solvents through a closed

der as well as the container (drum, plastic bag) and pieces of equipment such as pipeline, chute, funnel, discharge pipe, etc. will be charged; electrostatic charges already present in the powder from prior handling can even augment this effect. Brush discharges can thus occur. Without grounding, there is even a possibility of sparking over between metal parts. Brush discharges occur when a plastic bag is shaken out, when a non-conductive drum is taken away from the funnel in the access port, or when a charged surface area on a drum is touched, for example with the hand. Since, during material charging operations, such discharges of static electricity will charge container (inerted) always occur near the feed opening of the apparatus (where readily explosive vapor/air mixtures are most likely to be found), such operations are particularly hazardous.

It should be noted that this type of handling in chemical plants is one of the most frequent causes of accidents originating from electrostatic charges.

\section{Measures:}

- Whenever possible, charge first the solid solvent-free substance followed by the solvent.

- If the powder has to be added to containers, bottles or reactors containing a flammable solvent, it is nowadays the state of the art to do this only in a closed way and to inert the enclosure prior to this operation. Depending on the type of lock system applied, it must be considered that considerable quantities of air, and thus oxygen, may be entrained into the inerted enclosure. This applies especially to powders of low bulk density.

- If in exceptional cases the closed addition to inerted containers, bottles or reactors is technically not possible, the special precautions given below must be strictly followed.

\subsubsection{Closed charging of solids into an inerted apparatus}

For solvent-free powders: If the quality of the lock system allows a classification of the area around the manhole according to zone 2 and the presence of an explosive atmosphere from other sources have not to be expected, any type of drum or charge container is permitted. With this type of handling, solvent-free powder may even be poured into the charging device from non-conductive containers or plastic bags.

For powders containing flammable solvents: only conductive, grounded containers are permitted. Powders containing solvents must not be poured into the charging device from nonconductive plastic containers or plastic bags (Fig. 28 and 29). 


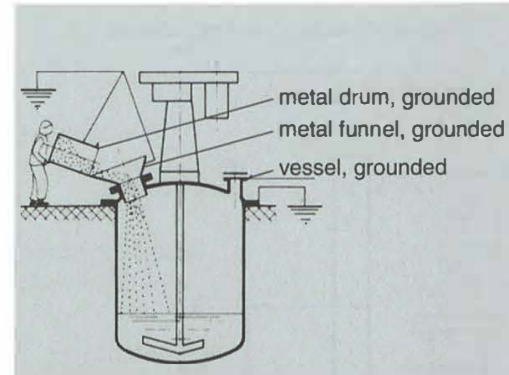

PERMITTED

for solids containing flammable solvent or precharged flammable solvent

Figure 30: Open charging of powder into flammable liquid (permitted)

3.2.2.2 "Open" charging of powders into flammable liquids or "open" charging of powders containing flammable liquids into an empty vessel when an inert atmosphere cannot be maintained

(see also 3.1.2, page 13, hybrid mixtures).

\section{Hazard:}

Decisive for the hazard situation and consequently for the type of measure to be taken are the following criteria:

- The flash point of the flammable liquid already in the vessel or present in the powder as moisture;

- the working temperature, i.e. the temperature of the flammable liquid during the charging operation or the highest temperature it can reach during that operation;

- the combustibility and the minimum ignition energy of the solid being charged.

\section{Case A}

- The powder is either not combustible or its minimum ignition energy (measured for the fine fraction of the powder) lies in the range $\geq 100 \mathrm{~mJ}^{10}$,

- and the working temperature is, with certainty, at least $5^{\circ} \mathrm{C}$ below the flash point (closed

10 This limit was set arbitrarily as a temporary measure; extensive investigations are being carried out to check its validity.

11 "Conductive" plastic is permissible only if the conductivity has been verified by measurement.

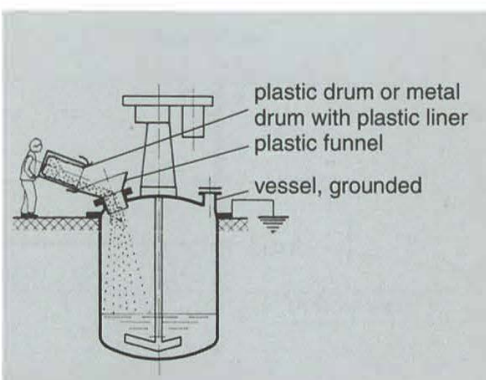

FORBIDDEN

for solids containing flammable solvent or precharged flammable solvent

Figure 31: Open charging of powder into flammable liquid (forbidden)

cup) of the flammable liquid (normal scatter of flash point determinations is $\pm 5^{\circ} \mathrm{C}$ ). In addition, possible quality variations of the liquid have to be considered: they could cause flash point fluctuations of several ${ }^{\circ} \mathrm{C}$.

\section{Measures for case A:}

- The choice of materials for construction of container, funnel, chute, etc. is not restricted, plastic bags are also permitted.

- Any parts made of conductive materials must be interconnected and grounded.

\section{Case B1: Open charging of pow-} der into precharged solvent

- The powder to be charged is combustible. Its minimum ignition energy (measured for the fine fraction of the powder) is $\leq 100$ $\mathrm{mJ}$ or unknown, and/or

- adherence to the flash point/temperature condition stated for case A cannot be guaranteed.

\section{Measures for case B1:}

- Drum or container, funnel, 'chute, etc. must be of conductive material and must be grounded. ${ }^{11}$

- The floor must be electrostatically conductive and operating personnel must wear conductive shoes (Fig. 30).

- The use of containers (whether conductive or not) with loose plastic liners or of containers, packings, etc. with a non-conductive coating is forbidden. However, conductive containers with an inner insulating coating or liner are permissible if the following conditions are met: the thickness of the insulating material does not exceed $2 \mathrm{~mm}$; the insulating material is in intimate contact with the conductive surface of the container and cannot become loose. For all product transfer operations, reliable grounding of the conductive part of the container must be assured (Fig. 31).

- All external ignition sources (e.g. open flames, grinding or impact sparks) must be excluded.

- Shovels used for charging must be either of wood and have a wooden handle or of metal and grounded.

- Bulk quantities must be charged in lots of no more than $50 \mathrm{~kg}$, with an interval of approx. $1 / 2$ minute between charges.

- Open charging in the presence of carbon disulfide, hydrogen or acetylene is forbidden.

This procedure makes great demands on the reliability of the operating personnel and places a particularly high degree of responsibility on the supervisory staff and plant management.

\section{Case B2: Open charging of} solvent-wet solids into an empty vessel or container

- When product containing solvent is charged into an empty vessel, the electrostatic charge accumulated on the product can constitute a hazard over and above that due to charges on the container and parts of the equipment or plant.

When the product piles up, a dangerous accumulation of electrostatic charge may take place (depending on the individual discharge behavior of the product in question), and when a grounded metallic object approaches (e.g. the moving paddle during charging in a paddle drier) brush discharges may occur.

\section{Measures for case B2:}

- As a consequence, open charging of solvent-wet products in an empty vessel or apparatus under the conditions described for case 
B1 is acceptable only if the resistivity of the product "as obtained" (i.e. solvent-wet) is below $10^{8} \Omega \cdot \mathrm{m}$. All other cases require inerting.

- Experience indicates that the resistivity will be above $10^{8} \Omega \cdot \mathrm{m}$ in the case of an organic, carbonfree powder and a non-polar solvent (e.g. white spirit, heptane, diisobutylene, toluene). In the case of polar solvents (e.g. methanol, isopropanol), this value is mostly below $10^{8} \Omega \cdot \mathrm{m}$.

\section{Notes:}

- The transfer of solvent-wet material from a container with plastic liner or from an insulated container into a conductive container is performed using a shovel. This requires a wooden shovel with wooden handle or a grounded metal shovel. Transfer by pouring is only permitted under good extraction. Plastic sacks must not be shaken out.

- Each time an inerted apparatus is opened, even if it is only for a very short time, air and therefore oxygen will always enter. The atmosphere inside the equipment can then become explosive. Only when small reaction vessels are used is it possible (with the aid of a special funnel, special equipment ventilation and exact regulation of nitrogen purging) to keep open the charging opening and still maintain perfect inerting:

A special funnel is fitted into the access port of the inerted reactor and connected securely to the equipment ventilation system. The gas space of the vessel is purged with an excess of inert gas; the excess escapes through the "open" vessel ventilation. The required quantity for purging must be established by means of oxygen measurement for each individual case; it is in the range $0.5 \mathrm{~m}^{3} \cdot \mathrm{h}^{-1}$ (for a 50 liter vessel)

\footnotetext{
${ }^{12}$ As a rule, powders containing less than 0.5 wt \% flammable solvent can be considered solvent free in this connection.
}

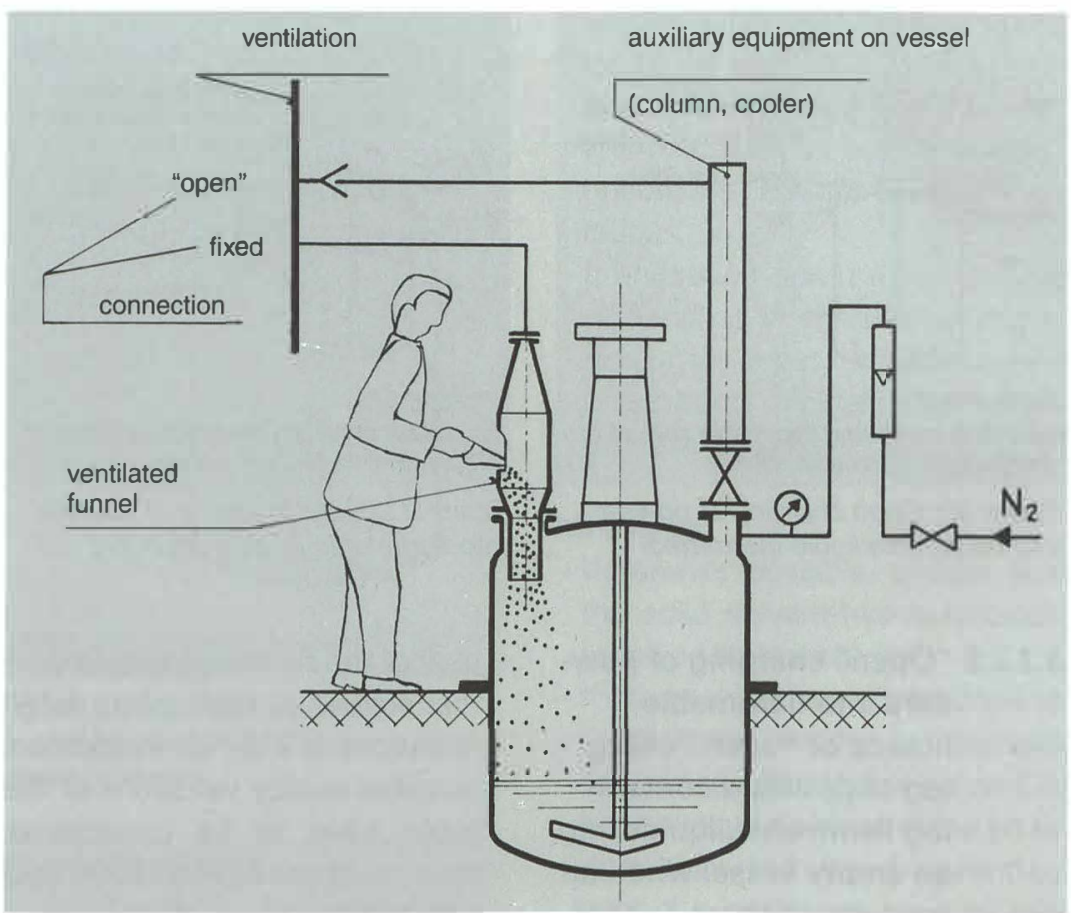

Figure 32: Open charging of solvent-wet solid into an inerted vessel with a ventilated funnel

to $8 \mathrm{~m}^{3} \cdot \mathrm{h}^{-1}$ (for a 1600 liter vessel). Substances can now be charged and samples taken through the charge opening of the funnel without the oxygen concentration in the reactor exceeding 8 vol. \% and without gases or vapors escaping into the work room. The dimensions of the special funnel must be matched to the size of the reaction vessel (Fig. 32).

\subsubsection{Discharging solids that contain flammable liquids ${ }^{12}$ from Nutsch filters, centrifuges and other filtration apparatus}

\section{Hazard:}

- Depending on the temperature of the solvent wet material handled and on the flash point of the solvent, an explosive vapor/air mixture can be formed.

- When a skimmer centrifuge is discharged, an explosive dust/air/ vapor mixture (explosive hybrid mixture), may be generated. Depending on the nature of the product, formation of dusts has been observed with up to $10 \%$ solvent content of the discharged material.
- On filter cake, filter cloth and isolated metal parts, charges may accumulate.

- When a grounded, conductive object is approached, sparks or brush discharges may lead to ignition.

\section{Measures:}

- Use effective local ventilation (e.g. suction hood) wherever possible; e.g. connect Nutsch filter to equipment ventilation but open throttle in suction line only as wide as necessary for the discharge operation.

- Use wooden shovels with wooden handles or grounded metal shovels.

- The discharge chute on a centrifuge must be conductive and grounded.

- Whenever possible, the solventwet material should be filled into conductive, grounded containers without plastic liner.

- Whenever possible use conductive filters. Non-conductive filters must be withdrawn from the apparatus (e.g. for cleaning, replacement) slowly. 


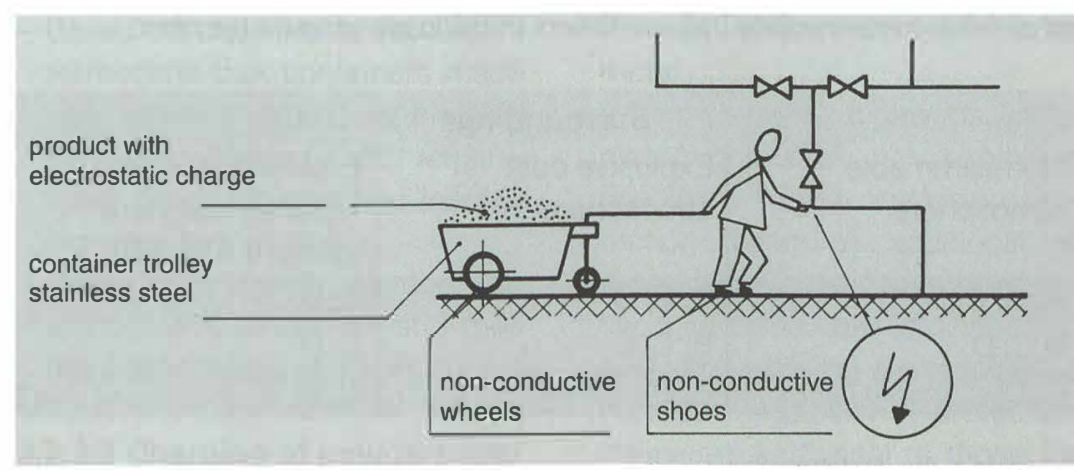

Figure 33: Entrainment of electrostatic charges by transporting charged product

Note:

- There are closed agitated pressure filters and centrifuges which can be discharged automatically with acceptable inerting. But hazards can still exist in the discharge duct and at the filling point of the receiver if these areas are not inerted.

\subsubsection{Charging and emptying} of drums and other containers

Hazard:

- On non-conductive surfaces (inner surface of a non-conductive plastic container or plastic liner), friction and separation processes can lead to the accumulation of high charges. When a conductive object approaches, or during particularly fast separation processes (e.g. powders sliding down a chute), corona or brush discharges are possible. These discharges can ignite solvent-wet powders.

- Conductive containers can be charged by separation processes when powders are added to or discharged from them. Sparks are possible.

\section{Measures:}

- Use conductive containers without plastic liner for solvent-wet material.

- Conductive container must be grounded or placed on a conductive floor.

- Dry powders may only be poured from non-conductive containers in the absence of flammable gases or vapors (see page 15 , case A).

\subsubsection{Special problems specific to certain types of equip- ment}

\subsubsection{Entrainment of electro-} static charges

\section{Hazard:}

- When a highly charged product is added to a conductive container, the latter will also be charged if it is not grounded. When a grounded conductive object approaches - this may be an operator wearing conductive shoes - sparking over can occur. If the operator handling such a container wears non-conductive shoes, sparking is still possible when he touches a grounded conductive object (e.g. metal pipeline, Fig. 33).

\section{Measures:}

- Fit transport containers with conductive wheels.

- Wear conductive shoes.

- Keep wheels and shoes clean.

- Check conductivity periodically by measurement.

\subsubsection{Filling and emptying} flexible intermediate bulk containers ("big bags")

\section{Hazards:}

- When filling and emptying flexible intermediate bulk containers (F|BC or "big bags"), electrostatic charging of the bulk product and the flexible container is to be expected. This can lead to various forms of electrostatic discharge. Depending on the type of explosive atmosphere present, these discharges may act as ignition sources.

- The measures described below are concerned with avoiding those hazards which are directly associated with electrostatic charging of the flexible bulk container itself. Regardless of the type of container, when handling large quantities (greater than approx. $1 \mathrm{~m}^{3}$ ) of extremely ignitable (minimum ignition energy less than $3 \mathrm{~mJ}$ ) or solvent-wet bulk product, there may be a need for additional explosion protection measures such as velocity limitations or inerting. Such measures may also be necessary when emptying the bulk product into already charged flammable solvent. On the other hand, it need not be expected that products with a minimum ignition energy greater than approximately $1 \mathrm{~J}$ will be ignited by electrostatic discharges from flexible intermediate bulk containers.

- Regardless of the characteristics of the bulk product, potential explosion hazards in the surrounding area (e.g. solvent vapors) must be considered.

- When filling or emptying flexible intermediate bulk containers, the following types of discharge are possible:

- Brush discharge

- Spark discharge (if the flexible bulk container is conductive)

- Propagating brush discharge

- Cone discharge

Gases, vapors, and hybrid mixtures can be ignited by all four types of discharge. On the other hand, solvent-free dusts are only ignited by spark, propagating brush or cone discharges, and only if their minimum ignition energy is $1 \mathrm{~J}$ or less.

\section{Measures:}

When filling and emptying flexible intermediate bulk containers, attention must be paid not only to the explosibility of the bulk product, but also to potential explosion hazards in the surrounding area. Depending on the specific situation in the plant in question, different characteristics of the flexible intermediate bulk containers are required (see Table 5, page 18). 
Table 5: Characteristics $A, B, C$ or $D$ required of flexible intermediate bulk containers (FIBC) depending on the plant situation [1]

\begin{tabular}{l|l|l|l|}
\hline $\begin{array}{l}\text { Bulk product } \\
\mathrm{MIE}_{\mathrm{OL}}{ }^{*} \text { of dust }\end{array}$ & $\begin{array}{l}\text { Non-flammable } \\
\text { atmosphere }\end{array}$ & $\begin{array}{l}\text { Explosive dust } \\
\text { atmosphere }\end{array}$ & $\begin{array}{l}\text { Explosive gas and } \\
\text { vapor atmosphere } \\
\text { (group II A or II B) }\end{array}$ \\
$\mathrm{MIE}_{O L}{ }^{*}>1000 \mathrm{~mJ}$ & A, B, C, D & B, C, D & C, D \\
\hline $1000 \mathrm{~mJ}>\mathrm{MIE}_{\mathrm{OL}}{ }^{*}>3 \mathrm{~mJ}$ & B,C, D & B, C, D & C, D \\
$\mathrm{MIE}_{O L^{*}}<3 \mathrm{~mJ}$ & $\mathrm{C}, \mathrm{D}$ & $\mathrm{C}, \mathrm{D}$ & $\mathrm{C}, \mathrm{D}$ \\
\hline
\end{tabular}

* Minimum ignition energy determined with no induction in the discharge circuit.

Provided that the flexible intermediate bulk containers used in the various plant situations (according to Table 5) fulfill the corresponding requirements $A, B, C$ or $D$ described below, and flexible intermediate bulk containers for requirement $\mathrm{C}$ are correctly grounded, there is no reason to expect ignition hazards resulting from electrostatic charges when filling or emptying flexible intermediate bulk containers.

- Products containing solvent (solvent content greater than $0.5 \%$ by weight, flash point of solvent below $55^{\circ} \mathrm{C}$ ) must not be filled into flexible bulk containers.

\section{Required characteristics of flexible intermediate bulk containers:}

\section{- Requirement A:}

No special requirements. From the point of view of static electricity, all types of flexible intermediate bulk container may be used.

\section{- Requirement B:}

The electrical breakdown voltage of the container fabric must not exceed $4 \mathrm{kV}$, to prevent occurrence of propagating brush discharges.

\section{- Requirement C:}

The material of the flexible container, including carrying straps, must be electrostatically conductive, i.e. at every point on the inside and outside of the flexible intermediate bulk container, the grounding resistance must be less than 100 megohms $\left(10^{8} \Omega\right)$. The flexible intermediate bulk container must be fitted with a grounding lug. The conductivity and requirement for grounding must be made visible by corresponding markings.

If the fabric of the Type C FIBC is covered with a non-conductive coating, the breakdown voltage of the coating must be less than $4 \mathrm{kV}$.

Flexible intermediate bulk containers according to requirement C must be grounded for every filling and emptying operation.

\section{- Requirement D [1]:}

The key factor in the design of FIBC Type $D$ is the removal of charge by low energy corona discharges. FIBC Type D are usually made from non conductive fabric containing conducting threads or filaments which are not interconnected. Grounding of FIBC Type $D$ has only a minor effect on charge dissipation and is not required. Some FIBC are supplied with an additional low resistivity coating to further reduce the incendivity of the discharges.

In contrast to FIBC Type B and C, there exist no simple requirements of physical parameters to ensure the safe discharge mechanism. FIBC Type D shall only be used in the presence of a flammable atmosphere after they have been qualified as safe - i.e. after it has been demonstrated that no incendive discharges will occur. In general, these FIBC should not be used in a flammable atmosphere of explosion group IIC.

Though grounding of the FIBC
Type D itself is not required, grounding of all objects and personnel in the surroundings of the FIBC Type D, which may become charged during filling or emptying due to electrical induction or charge spraying, is required. Thus, any conductive items that may not normally be grounded (e.g. drums on pallets) should either be grounded or removed from the vicinity of the FIBC Type D. In addition, conductive items (e.g. working tools, bolts and clips) shall not be placed or stored on the FIBC. When the FIBC is supplied with a means to reduce the final residual charge on its surface (e.g. a low resistivity surface coating) the requirement of grounding conductive items in all but the immediate vicinity of the FIBC may possibly be relaxed. In the order to prevent incendive spark discharges from the surface of the FIBC it shall not become contaminated or coated with conductive material (e.g. water, grease or oil).

In the case of FIBCType D the complete FIBC must also be tested.

\section{Notes:}

- Flexible intermediate bulk containers can be tested in the laboratory for fulfillment of requirements $B$ and $C$. To test the breakdown voltage (requirement $B$ ) a sample of approximately $20 \mathrm{~cm} \times$ $20 \mathrm{~cm}$ is sufficient. The conductivity (requirement $\mathrm{C}$ ) can only be tested on the entire flexible intermediate bulk container. In case of type D FIBCs the entire FIBC also has to be tested. 
- Based on experience, flexible intermediate bulk containers made from woven polypropylene with a thin inner coating fulfill requirement B provided that no insulating inner bag is used.

- Liners may totally change the electrostatic properties and thus the classification of a FIBC.

\subsubsection{Charging of powders into large containers (silos)} Hazards:

- During charging, an electrostatically-charged dust cloud is created; if sufficiently large field strengths and very large volumes are involved, the occurrence of a lightning-like discharge could be envisaged. No cases are known in practice.

- In powders of low conductivity, charges will accumulate in the product deposit causing continual small brush discharges. Under certain circumstances, high-energy discharges may also occur on the surface of the deposited powder. These so-called cone discharges are of particularly high energy and therefore represent a high hazard when charging coarse-grained products (grain size $\geq 1 \mathrm{~mm}$ ). For estimation of the energy released in cone discharges see [1] Chap. A. 3.7, p. 71-72.

- Inadvertently entrained isolated conductive objects within the silo will be charged and form a capacitor with the silo le.g. tools dropped into the silo, metal filings in the incoming powder).

\section{Measures:}

- No insulating internal coating or use of an inner coating with maximum $4 \mathrm{kV}$ breakdown voltage.

- In silos with a diameter $>3 \mathrm{~m}$ the field strength must always be $<500 \mathrm{kV} \cdot \mathrm{m}^{-1}$ (no restriction for silos with $\varnothing \leq 3 \mathrm{~m}$, lightning discharge impossible). This must be verified by measuring the field strength.

\footnotetext{
${ }^{13}$ See footnote 8, page 13.
}

- Prevent entrainment of tramp metal.

- When charging highly-insulating plastic granulate with explosive fine dust, further explosion protection measures additional to those for the avoidance of effective ignition sources (e.g. inerting, explosion venting) are required.

- Further explosion protection measures additional to those for the avoidance of effective ignition sources (e.g. inerting, explosion venting) may also be required when charging highly insulating powdery solids with extremely low minimum ignition energy $(\mathrm{MIEOL})^{13}$ into large silos and containers. Assessment of ignition hazard from cone discharges is required and expert advice is highly recommended.

\subsubsection{Spray drying, fluid bed drying}

\section{Hazard:}

- High charging of the substances (powders and possibly pellets) due to the high-speed separation of the particles in a very dry atmosphere both in the dryer itself and in the dust separator (cyclone) or filter. Charging of apparatus parts that come into contact with the powder leading to incendive spark discharges, especially if combustible dust and flammable vapors or gases are present simultaneously.

Flammable gases or vapors may be ignited with $1 / 100$ to $1 / 10$ of the energy required to ignite dusts.

- Mixtures of combustible dusts with flammable gases or vapors in air (so called hybrid mixtures) may be explosive even when the concentration of the individual components is below their respective lower explosion limits (see section 3.1.2 on hybrid mixtures, page 13).

\section{Measures:}

- All metal parts of the apparatus housing must be interconnected and grounded; internal metal installations such as screens, locking rings, spray nozzles, filter sup- ports and accessories such as receivers and transfer throughs must be grounded. Individual nuts and bolts need not be grounded.

- If conductive filters are used (necessary only if combustible dust and flammable vapors or gases are present simultaneously, or the MIE of the dust is $<3 \mathrm{~mJ}$ ) the filter cloth must contain fine metal fibres (> $5 \%$, uniformly distributed) which are spun into the individual threads of the fabric. Filter cloth with separate wires or braided wires is hazardous: if such a wire or braided wire breaks, a spark gap is created.

- Inerting of dryers: If, for inerting purposes, combustion gases are used instead of nitrogen, their composition loxygen concentration, concentration of flammable components) must be monitored, and controlled by suitable instruments and safeguards.

\subsubsection{Dust-carrying pipelines (ventilation ducts, blow- off pipelines on con- tainers, dust-extraction pipelines, pneumatic conveyors)}

\section{Hazard:}

- The continuous separation processes between the conveyed substance and the pipeline cause both the conveyed substance and the pipeline to become charged.

- Discharge sparks may be emitted from ungrounded conductive pipeline components or flanges.

- In the case of very intensive separation processes (high speed and high dust concentration), propagating brush discharges may occur on insulating pipelines or on conductive pipelines with an insulating inner coating.

- On insulating pipelines, brush discharges may occur which present an ignition hazard if at the same time flammable gases or vapors are present inside or outside the pipeline.

\section{Measures:}

The measures to be taken depend on the anticipated intensity of 
charge (speed of conveyance, dust concentration) and on the type of explosive atmosphere which may possibly be present. Depending on the type of pipeline, the following measures are recommended:

- Space ventilation ducts (flow velocity low, $<10 \mathrm{~m} \cdot \mathrm{s}^{-1}$; dust and

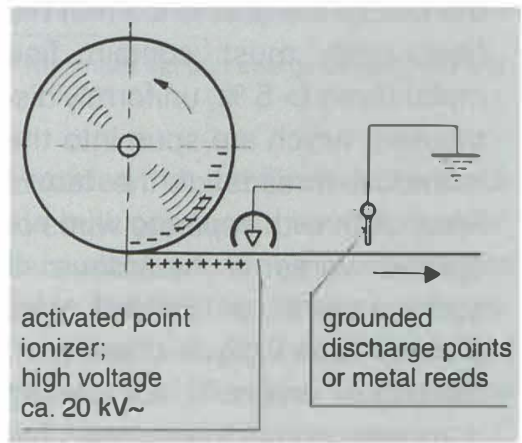

Figure 34: Charge dissipation by point ionizer or metal reeds

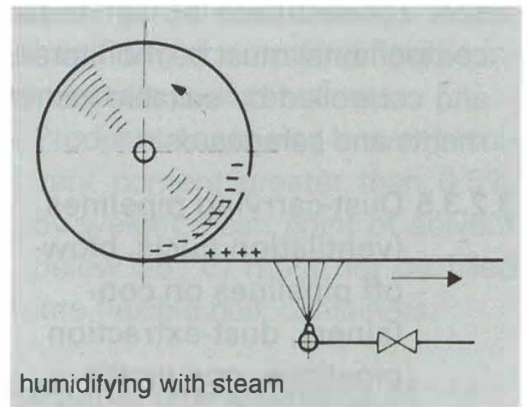

Figure 35: Charge dissipation by increasing humidity

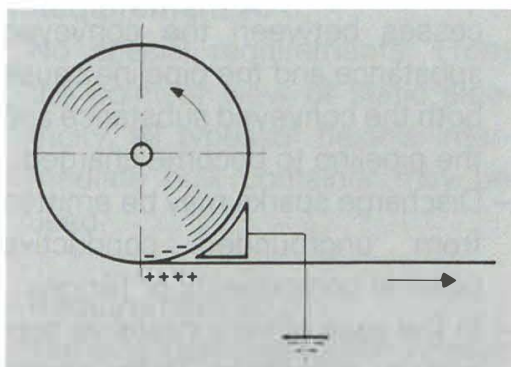

grounded conductive wedge

Figure 36: Charge dissipation by metal wedge

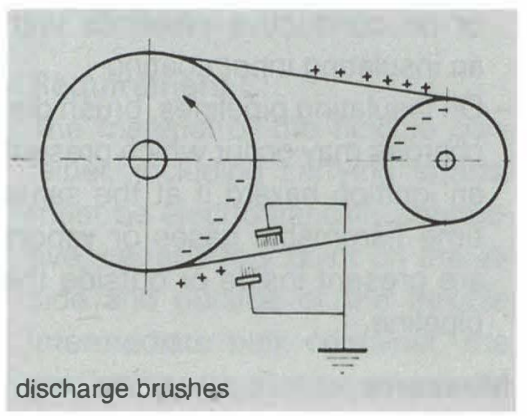

Figure 37: Charge dissipation by conductor brushes droplet concentration (ow): Insulating plastic pipelines are permitted. In areas where flammable gases or vapors must be expected, brush discharges caused by external friction must be avoided (e.g. installation on the ceiling) and conductive parts (e.g. valves, flanges, supporting brackets) must be grounded.

- Blow-out pipelines on containers (high flow velocities, droplets and dust particles are entrained): Such pipelines are mainly located in areas where flammable gases or vapors must be expected. Conductive, grounded pipelines must be used of a width (and therefore cross-section) which reduces the flow velocity to less than $10 \mathrm{~m} \cdot \mathrm{s}^{-1}$.

- Dust-extraction pipelines (flow velocity approx. 10-20 $\mathrm{m} \cdot \mathrm{s}^{-1}$, moderate dust concentration): Insulating plastic pipelines are permitted provided that flammable gases or vapors will not occur either inside or outside the pipeline. Otherwise conductive grounded pipelines must be used. Conductive parts on insulating pipelines (e.g. valves, flanges, supporting brackets, metal spirals) must be grounded.

- Pipelines of pneumatic conveyors: Use conductive, grounded pipelines. Insulating internal coatings and painting are permitted provided the breakdown voltage is $<4 \mathrm{kV}$.

\subsubsection{Dust filters}

Hazard:

- Accumulation of electrostatic charges on the dust deposit, the filter material, and filter supports; incendive discharges are possible when the dust falls off, when it is shaken off, or when the filters are handled.

\section{Measures:}

- Conductive filter supports, including locking rings, clamp straps, etc., must be grounded.

- If the MIE $\mathrm{EL}_{\mathrm{L}}$ is $<3 \mathrm{~mJ}$ or the presence of flammable solvents is suspected (e.g. in dust filters of paddle driers, fluid bed apparatus), conductive filters (> $5 \%$ metal fibers spun into the threads of the cloth homogeneously distributed) should be used.

- When separating dusts with low minimum ignition energy $\left(\mathrm{MIE} \mathrm{E}_{\mathrm{OL}}\right.$ $<10 \mathrm{~mJ})^{14}$ in large filters, further explosion protection measures going beyond the avoidance of effective ignition sources may be necessary (e.g. inerting, explosion venting, explosion suppression).

\section{Note:}

- It should be noted that when, in exceptional cases, a filter housing has to be opened while flammable vapors are still present, it is advisable to check for the presence of electrostatic charges with a meter and to dissipate such charges with a grounded metal point before any manipulations are carried out. This procedure should be left to a specialist on static electricity.

\section{Moving parts on machines and apparatus}

\section{Drive belts, conveyor belts, rollers, cylinders, foils, cloth,} etc.

Hazard:

- Depending on the material, width, and speed of the rotating parts, the continuous separation of two touching surfaces generates electrostatic charges which can lead to incendive sparks.

\section{Measures:}

- Use drive belts, belt pulleys, conveyor belts, cylinders, idlers, etc. made of conductive material.

${ }^{14}$ See footnote 8, page 13. 
The following should be noted:

- As a rule, when the shafts and drive pulleys of agitator vessels, kneaders, driers, etc. are in motion, they need not be grounded, since the connection to ground via bearings and stuffing boxes suffices. Lubricating agents with admixtures of graphite or molybdenum sulfide help to improve the conductance. In doubtful cases, check the moving parts for grounding (measure resistance to ground).

- Charges on paper, textiles, or plastic webs are best conducted away by means of ionized air, by point ionizers, metal reeds (Fig. 34), by greatly increasing the local humidity (Fig. 35), metal wedges (Fig. 36) or by conductor brushes (Fig. 37).

- It is most unlikely that explosive mixtures (minimum ignition energy $>0.025 \mathrm{~mJ}$ ) will be ignited when electrostatic charges are dissipated by means of grounded points or reeds.

\section{The human body as a carrier of electro- static charges}

\section{Hazard:}

- Charging of the human body; sparking when a grounded object is approached (e.g. agitator vessel, metal pipeline).

\section{Measures:}

- Wear conductive shoes (leakage resistance through soles $<10^{8} \Omega$ ) and use a conductive floor.

\section{Correct:}

Safety shoes with conductive soles; shoes with leather soles.

Incorrect:

Plastic shoes, crêpe soles.

- Have conductivity of footwear measured periodically.
Note:

- Wearing normal commercial clothing does not usually result in hazardously high static charging provided the wearer is grounded.

- Note, however, that when clothing made of synthetic fiber is removed, extremely high charges and hence brush discharges may arise (separation effect). Clothes must therefore never be changed when an explosive atmosphere is present.

\section{Hints for planning and construction}

Electrostatic charges are an especial hazard in places where they can, under certain circumstances, cause ignition. But even in areas where there is no special fire hazard they can be a nuisance and cause accidents or technical difficulties. When planning a new building or plant it is therefore essential to pay the necessary attention to problems of static electricity from the outset. Appropriate choice of materials and type of construction, for example allowing space for charging airlocks, allows later inconvenience to be avoided at practically no expense.

\subsection{Buildings}

The actual structure (shell) of the building can be considered sufficiently conductive for static electricity for the following types of building:

- steel structure

- concrete structure with brickwork

- wooden structure.

Wooden structures, however, must be not used as grounding conductors.

It is advisable, even for rooms without special hazards (offices, corridors, cafeterias, libraries, computer rooms, etc.), to use floors and carpets with antistatic finish. Office chairs with appropriate antistatic finish are also available. Handrails on banisters should be conductive.

\subsection{Floors}

\section{Hazard:}

- Persons can become charged when walking on a non-conductive floor owing to the constant separation effect between their shoes and the floor. Sparking is possible when a grounded object is approached.

\section{Measures:}

- Use conductive material for floors.

- Keep floors made of asphalt or plastic material damp or wet.

- In special cases, a floor can be made sufficiently conductive by washing it with aqueous glycerine ( $1 \%$ glycerine in water). However, such treatment must be repeated every few weeks.

Note:

- It should be noted that the following floors can be considered sufficiently conductive:

- Concrete floors (clean)

- Wooden floors that are untreated and where the relative humidity of the surroundings is higher than $65 \%$

- All sheet metal floors and metal grids.

- The following floors must be considered non-conductive:

- Painted or plastic-coated concrete floors

- Concrete floors highly contaminated with lacquer, resin, dust or oil

- Dry asphalt floors when the relative humidity of the surroundings is below $40 \%$

- Plastic tile and synthetic resin floors

- Sealed parquet floors

- Carpeted floors.

Antistatic (conductive) plastic floors and carpets are obtainable. As a rule, the latter require a certain minimum atmospheric humidity to be maintained.

\subsection{Atmospheric humidity}

The conductivity of air shows little or no improvement even when the atmospheric humidity is greatly increased. Static charges cannot be 


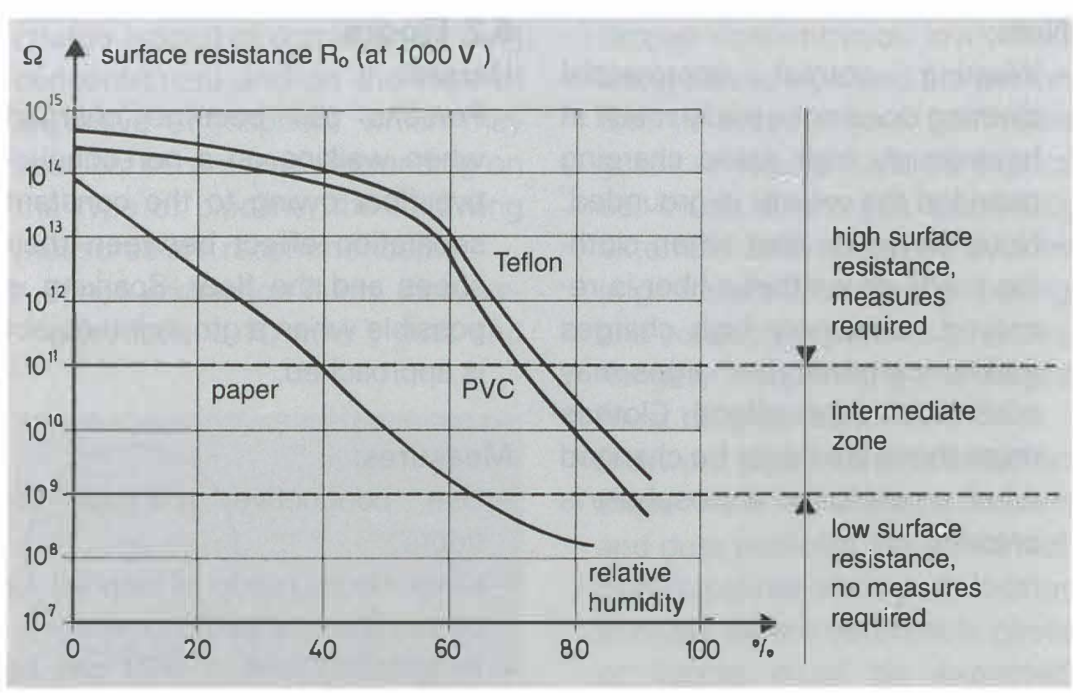

Figure 38: Surface resistance versus relative humidity

sufficiently dissipated by moist air. Increasing the humidity of the air as such is therefore not a recognized protective measure. However, the surface resistance of solid insulating materials can be reduced if the relative humidity is above $65 \%$, since the surface of such materials always has a certain layer of impurities on which a conductive film of liquid will be formed. The humidity has a great influence on the chargeability of substances such as textiles, paper, etc. However, general humidification above $65 \%$ is too costly, especially in ventilated rooms, and can cause unacceptable conditions at the workplace. Humidification is best applied locally and selectively, e.g. by spraying or moistening (with steam, for instance) the paper or fabric webs (Fig. 38).

\subsection{Suggested values for surface resistance and resistance to ground}

For the prevention or dissipation of charges, the following should be adhered to:

- The resistance to ground of individual conducting parts should be less than $10^{6} \Omega$ (smaller parts up to $10^{9} \Omega$ ).

- The surface resistance of insulating materials should be less than $10^{9} \Omega$ at $50 \%$ relative humidity or less than $10^{11} \Omega$ at $30 \%$ relative humidity.

- The resistance of drive belts $(\Omega)$ multiplied by their width $(\mathrm{m})$ should be less than $10^{5} \Omega \cdot \mathrm{m}$.

\subsection{Important practical rules}

- Steel girders of the building structure count as grounded.

- Metal pipes clamped to the building structure count as grounded.

- Completely enameled (also on the outside) mountings and flanges must be bridged conductively and grounded (see 6.7).

- Apparatus such as agitator vessels, receivers, measuring vessels, Nutsch filters, etc. made of metal which are securely connected to metal pipes count as grounded.

- Apparatus covers lagitator vessels, etc.) which are tightly screwed to the lower part, even if there is an insulating gasket (e.g. Teflon ring) in between, count as grounded. In the case of enameled vessels, it is advisable to check by measurement.

- Agitators, thermometer tubes, kneader blades inside apparatus require no special measures.

- Metal storage tanks with fixed metal pipes count as grounded. Use conductive hose material for temporary lines.

- Drive belts (flat belts and V-belts) must be conductive. If in doubt, have them checked.

- Transmissions: have the resistance to ground checked.

- In metal silos and pipes for prod- ucts in powder form, do not apply an insulating coating inside with a breakdown voltage higher than $4 \mathrm{kV}$.

- Glass pipes: plastic flanges for small glass pipes, despite the somewhat higher purchase price compared with metal flanges, work out cheaper since they do not have to be grounded. Metal flanges, valves, flaps, throttles, etc. with a nominal diameter including and greater than $50 \mathrm{~mm}$ must be grounded.

- Apparatus made of glass and porcelain (stills, agitator vessels, steam ejectors): metal flanges and metal parts must be grounded. Often they are already grounded via the metal supports.

- Plastic apparatus and pipes: metal parts, e.g. flanges with a nominal diameter $\geq 50 \mathrm{~mm}$, valves, flaps, support shells, protective pipes, etc. must be grounded. Individual metal bolts need not be grounded since their capacity is too small to generate a spark capable of acting as an ignition source.

- Conductive fittings and flanges on insulating pipelines with nominal diameter less than $50 \mathrm{~mm}$ must also be grounded if their size corresponds to fittings and flanges on pipelines with nominal diameter of $50 \mathrm{~mm}$ or greater.

Note:

In order to save space, temporary cables which are used only occasionally to ground movable apparatus can be wound on cable rollers which wind up automatically.

- The paint on metal pipelines can have an insulating effect if the individual parts are completely covered with paint prior to assembly.

- Paint systems are available with tested conductivity.

\subsection{Specifications for fixed ground connections}

To avoid possible ineffective grounding in the plant due to damage, the conductor must have an adequate cross section. The wire must be securely fastened or sup- 
ported and, where necessary, selective wire sections must be enclosed in a protective pipe. Recommendation for grounding conductors:

- copper wire or braid, cross section 1.5 to $2.5 \mathrm{~mm}^{2}$, color of insulation specified in local rules (in Switzerland green and yellow).

- Bare copper, diameter not less than $4 \mathrm{~mm}$.

Bridge connectors across enameled flanges should be made of flat copper, approx. $10 \times 1 \mathrm{~mm}$, and firmly screwed to one flange, so they will not be misplaced during inspections.

Terminals for grounding on flanges, valves, etc. must be in perfect contact with the metal object to be grounded:

- On enameled parts, the enamel must be ground off a small area, or a hole drilled in the metal body, if the situation demands it.

- On painted or powder-coated parts, serrated lockwashers should be used with the nuts and bolts employed to install the part. For large pipelines (e.g. ventilation lines) the use of bare copper rod as grounding conductor is recommended.

Regarding metal flanges on glass lines: it is not advisable to interconnect a large number of flanges for grounding purposes. If the grounding conductor is broken or torn off, the total capacitance of the flanges connected in parallel can reach hazardous values. For each pair of flanges it is sufficient to ground one flange, provided that

- the flanges are painted with conductive paint, or

- special serrated washers with edges which penetrate the paint are used.

\subsection{Grounding connection of metal parts on glass and plastic pipelines with diameter $\geq 50 \mathrm{~mm}$}

Example (Fig. 39): glassware connection to a reaction vessel (see section 6.6, page 22).

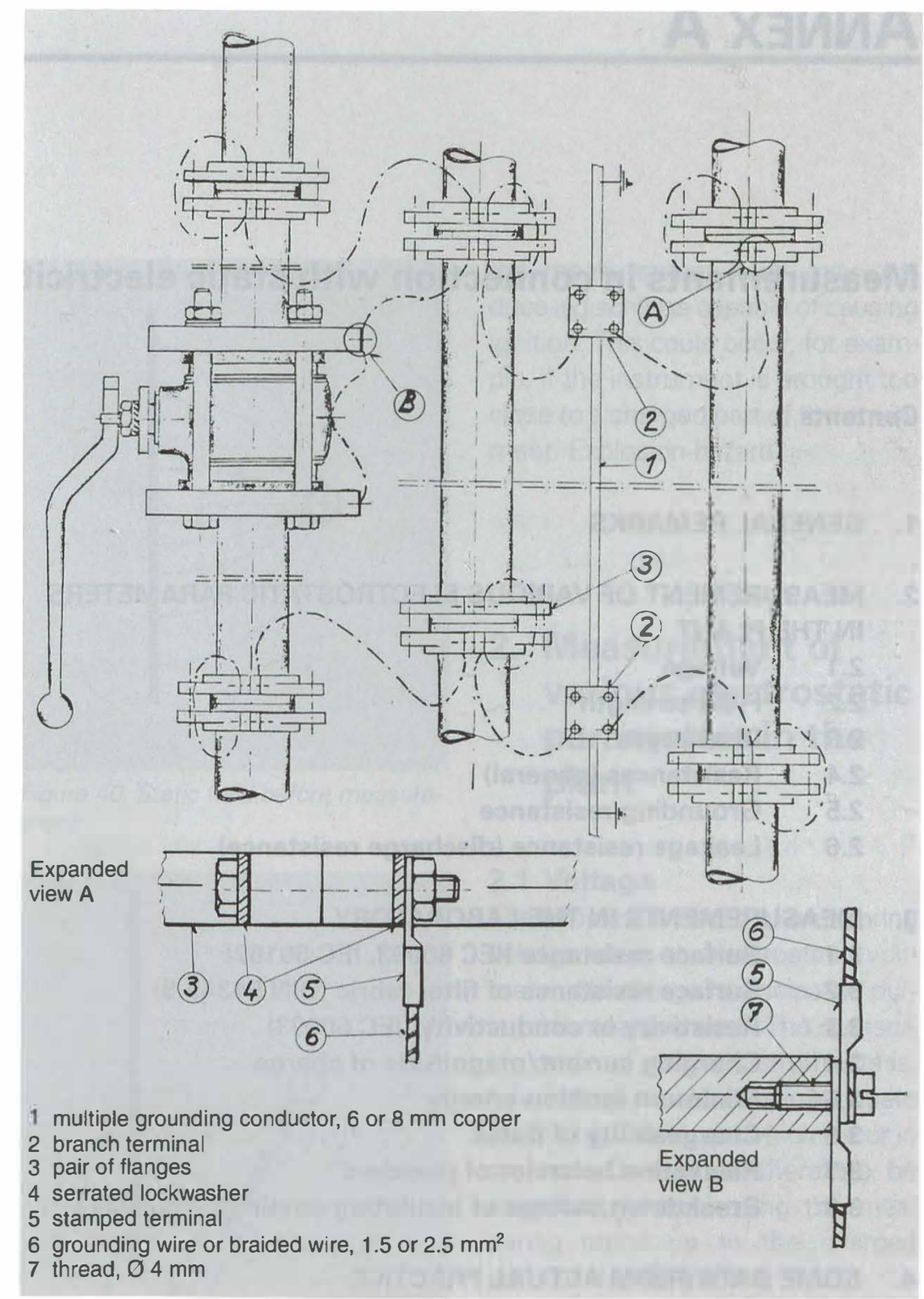

Figure 39: Grounding connection of metal parts on glass and plastic pipelines with diameter $\geq 50 \mathrm{~mm}$ 


\title{
Measurements in connection with static electricity
}

\author{
Contents
}

1. GENERAL REMARKS

2. MEASUREMENT OF VARIOUS ELECTROSTATIC PARAMETERS IN THE PLANT

$2.1 \quad$ Voltage

2.2 Field strength

Discharges

2.4 Resistances (general)

2.5 Grounding resistance

2.6 Leakage resistance (discharge resistance)

3. MEASUREMENTS IN THE LABORATORV

3.2 Surface resistance of filter fabric (DIN 54345-5) 27

3.3 Resistivity or conductivity (IEC 60093) 27

$\begin{array}{lll}3.4 & \text { Charging current/magnitude of charge } & 27\end{array}$

3.5 Minimum ignition energy 27

3.6 Chargeability of dusts 27

\begin{tabular}{ll}
3.7 & Relaxation behavior of powders \\
\hline 3.87
\end{tabular}

3.8 Breakdown voltage of insulating coatings (EN 60243-1) 27

4. SOME DATA FROM ACTUAL PRACTICE 27

Table 6 Potentials (voltages) 28

Table 7 Capacitances to ground 28

Table 8 Leakage resistances (discharge resistances) 28

Table 9 Resistivities of certain solids 28

Table 10 Resistivities of certain solvents 29

Table 11 Specific charge of dusts after pneumatic transfer 28

Table 12 Field strengths 28

Table 13 Minimum ignition energies in air 28

Table 14 Sensitivity of humans to discharges of static electricity 28 


\section{Measurements in connection with static electricity}

\section{General remarks}

The voltages involved in static electricity are relatively high. The charging currents, however, are very weak. The charges involved are also of a correspondingly low magnitude. This may be explained by the fact that the capacitors available for charging are extremely small compared with those occurring in power engineering. Such capacitances are in fact referred to in power engineering as "stray capacitances".

These circumstances give rise to the following main consequences for the technician carrying out measurements:

The measuring system (instruments, personnel) may cause considerable changes in the prevailing conditions with the result that the recordings do not represent the absolute values sought. Example: measurement of field strength with a grounded instrument. The measuring instrument concentrates the lines of force, thereby increasing the field strength accordingly. As a result, relative values often have to be accepted. It is, however, possible to answer the questions:

- Is it high or low?

- Has an improvement been achieved?

It is meaningless to make comparisons of absolute values obtained with different instruments and under different measuring conditions.

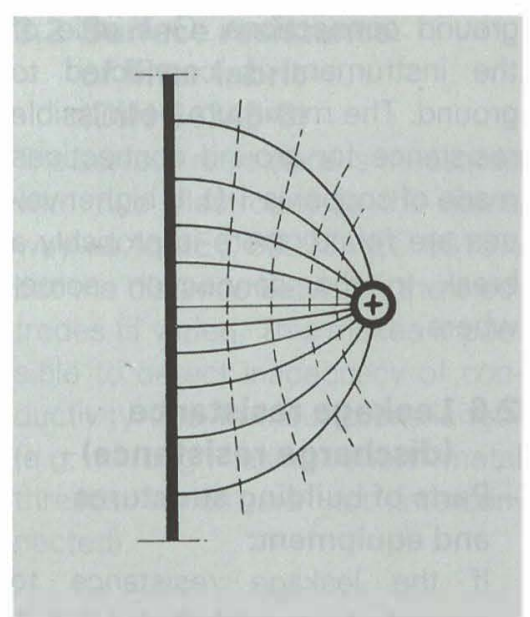

Figure 40: Static field before measurement

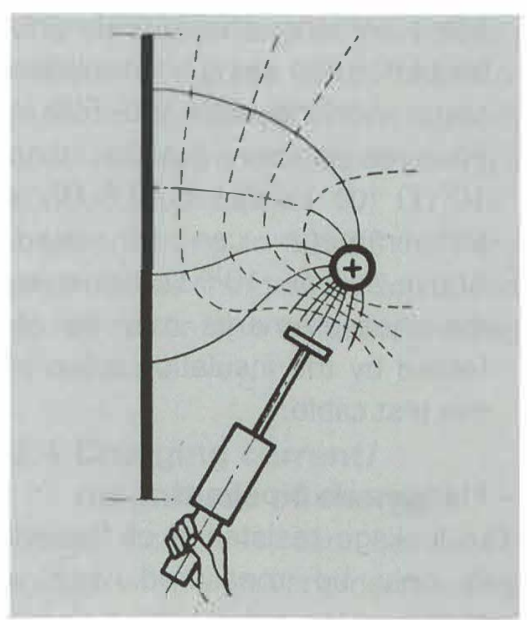

Figure 41: Static field during measurement

In practice, the most important question usually concerns the possibility of discharges (when the breakdown field strength of the air is reached), and whether such discharges are capable of acting as an ignition source (discharge energy). Knowledge of the field strength and the stored energy is therefore required. Whenever measurements are carried out, the ambient conditions (temperature, humidity) and the type of instrument used should be recorded.

Note that if measurements are performed in a plant during operation, the measurement itself may produce a discharge capable of causing ignition. This could occur, for example, if the instrument is brought too close to a charged part of the equipment. Explosion hazard!

\section{Measurement of various electrostatic parameters in the plant}

\subsection{Voltage}

The simplest method of measuring voltage uses an electrostatic voltmeter. No charge is dissipated during the measurement. The measuring range of pocket instruments is, however, in most cases inadequate for the high voltages which occur in practice. Care must therefore be exercised when moving the measuring probe up to the charged parts of the equipment.

\subsection{Field strength}

To determine the field strength at a given point and with a given geometry in $\mathrm{V} \cdot \mathrm{m}^{-1}$ or $\mathrm{V} \cdot \mathrm{cm}^{-1}$, instruments for measuring field strength (statometers) are used. However, the fact that the instrument is grounded via the person performing the measurement causes distortions in the field (Fig. 40 and 41). For a uniform field, the measured value can be multiplied by the distance to obtain the actual voltage relative to ground.

When the measuring distance is only a few centimeters, a special adapter for statometers allows the voltage to be measured directly: a radioactive source attached to the measuring probe renders the air conductive, so that a weak current 
leaks through the probe. It is therefore not possible to measure very weak charges (low capacitances) with a statometer.

The field strength measuring instrument designed by Schwenkhagen is more accurate than the statometer, but is also subject to the same adverse effects of field distortion. At field strengths above 200$300 \mathrm{kV} \cdot \mathrm{m}^{-1}$, brush discharges can be expected with appropriate geometry of the setup (e.g. when a fingertip approaches a charged surface).

\subsection{Discharges}

In large pieces of equipment, e.g. storage silos, it is often not possible to carry out measurements with the statometer during operation. In such cases, it may be possible to detect discharges (corona or brush) by means of a long-wave receiver when its measuring probe is inserted into the vessel concerned.

\subsection{Resistances (general)}

Most cases involve determination of whether a part of a building or plant is grounded or not, or alternatively, the value of its leakage resistance. Basically, the magnitude of the test voltage has a certain effect on the resistance measurement, since a certain minimum voltage is required to overcome transfer or contact resistances. Therefore, measurements performed at about 60-100 $\mathrm{V}$ give lower resistance values than those performed at, for example, 1.5 V. A suitable test voltage for static measurements is therefore $100 \mathrm{~V}$.

\subsection{Grounding resistance}

The simplest measurements are performed using a pocket ohmmeter. The measuring-circuit voltage of 1.5-6 $\mathrm{V}$ found in such instruments is adequate for checking ground connections. One pole of the instrument is connected to ground. The maximum permissible resistance for ground connections made of copper is $1 \Omega$. If higher values are found, there is probably a break in the connection somewhere.

\subsection{Leakage resistance (discharge resistance)}

\section{- Parts of building structures} and equipment:

If the leakage resistance to ground of equipment and structures does not exceed $10^{6} \Omega$, they will not become charged. Measurements should preferably be performed using an insulation tester working with 100-500 V. For resistances greater than $10^{7} \Omega$ (up to about $10^{14} \Omega$ ), a teraohmmeter can be used. Above approx. $10^{13} \Omega$, however, the measurements may be affected by the insulation value of the test cable.

\section{- Flanges on pipelines.}

The leakage resistance of flanges can only be measured with a teraohmmeter, since values above $10^{12} \Omega$ are not uncommon.

\section{- Transmission belts.}

The leakage resistance is measured

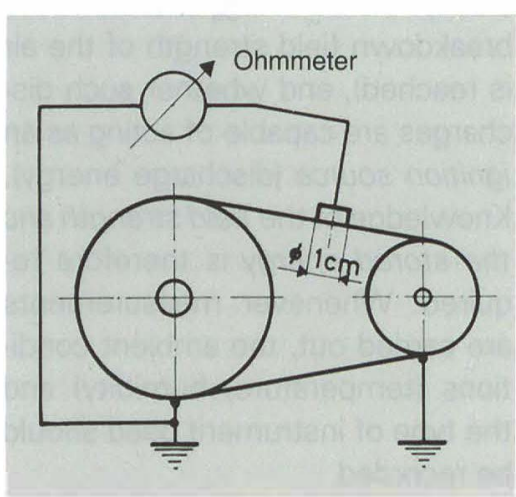

Figure 42: Measuring the leakage resistance of transmission belts as follows: both drive pulleys must be grounded. The electrode, approximately $1 \mathrm{~cm}$ in width, is laid on the belt midway between the pulleys (Fig. 42). The product of the measured resistance in $\Omega$, and the width of the belt in $m$, must not exceed $10^{5} \Omega \cdot \mathrm{m}$. In the case of V-belts, twice the width of the side of the $V$ in $m$ should be used. The measurement can be carried out using, for example, an insulation tester.

\section{- Floor surfaces.}

Measurement of the leakage resistance is performed according to EN 1081 and IEC 61340-4-1.

A metal electrode with an area of $20 \mathrm{~cm}^{2}$ is laid on the clean floor surface. To ensure perfect contact, a piece of conductive flexible rubber is inserted between the electrode and the floor. A teraohmmeter should preferably be used (Fig. 43). Floors with a leakage resistance of less than $10^{8} \Omega$ are regarded as electrostatic conductors. This limit is fixed low enough to allow a safety margin for additional resistances (e.g. from dirt or poorly conducting footwear). Electrostatic charges are, in fact, still dissipated relatively rapidly in the range $10^{8}-10^{9} \Omega$.

For example: given a total leakage resistance (floor and footwear) of

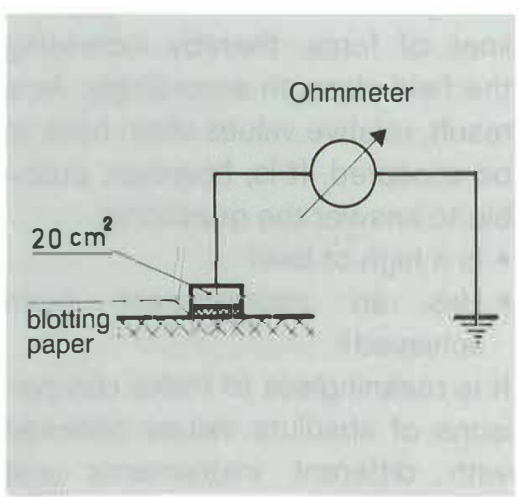

Figure 43: Measuring the leakage resistance of a floor surface 
$10^{7} \Omega$, an electrostatically-charged human body with a capacitance of around $100 \mathrm{pF}$ has a discharge time of approx. $5 \times 10^{-3} \mathrm{~s}$.

\section{- Footwear.}

Routine tests are carried out most simply using a "shoe tester". The person wearing the shoes to be tested steps onto a platform and holds two electrodes in their hands. The leakage resistance can be measured at a low voltage and should not exceed $10^{8} \Omega$. The leakage resistance is normally not increased significantly when stockings or tights are worn. The resistance of shoe soles should be not less than $10^{4} \Omega$ so as to afford some protection against contact with power equipment with defective grounding or insulation. However, in areas where an explosion hazard exists, electrostatic considerations (conducting soles) must have priority over protection against contact with faulty electrical equipment. Routine retesting of the conductivity of footwear is recommended.

\section{Measurements in the laboratory}

The measurements described below require special instruments and specially trained personnel:

\subsection{Surface resistance} (IEC 60093, IEC 60167)

Two electrodes, each of length 10 $\mathrm{cm}$, are laid $1 \mathrm{~cm}$ apart on the surface to be tested. The surface material is classified as being sufficiently conducting if the resistance between the two electrodes does not exceed $10^{9} \Omega$ at $23^{\circ} \mathrm{C}$ and $50 \%$ relative humidity or $10^{11} \Omega$ at $23^{\circ} \mathrm{C}$ and $30 \%$ relative humidity.

\subsection{Surface resistance of filter fabric (DIN 54345-5)}

The surface resistance is measured with two electrodes in the same way as for IEC 60093, IEC 60167. but the distance between the electrodes is varied. This makes it possible to detect inadequacy of conductivity due to insufficient length (e.g. through using short metal threads which are not interconnected).

\subsection{Resistivity or conductivity (IEC 60093)}

This parameter is principally determined for liquids. The measurement is performed with a special conductivity meter. Liquids having a conductivity below $10^{-8} \Omega^{-1} \cdot \mathrm{m}^{-1}$ (corresponding to $10^{4} \mathrm{pS} \cdot \mathrm{m}^{-1}$ ) are regarded as chargeable. Solids and powders can also be characterized in the same way.

\subsection{Charging current/ magnitude of charge}

These quantities can be determined with a galvanometer using specially designed test circuits. The results of the measurements cannot be applied directly to practical cases, but they provide very valuable information concerning, for example, the development of charges during the transport of various liquids, or the behavior of a liquid in vessels of various materials. For example, the charge produced per $\mathrm{kg}$ of liquid can be determined.

\subsection{Minimum ignition energy}

Values are available for some common solvents, but only for very few dusts (see Table 13, page 28).

\subsection{Chargeability of dusts}

When dusts are dispersed, screened, or pneumatically con- veyed, the charges generated are measured and reported in terms of unit mass. Special arrangements of the test apparatus allow comparison of the behavior of different dusts under identical conditions.

\subsection{Relaxation behavior of powders}

Charged powders in a conductive container lose their charge relatively rapidly. The resistivity of a powder gives a rough idea of the relaxation time expected. Relaxation times can also be measured directly with the aid of a special apparatus.

\subsection{Breakdown voltage of insulating coatings (EN 60243-1)}

The insulating coating for testing is laid on a grounded metal surface. A cylindrical electrode ( $\varnothing 25 \mathrm{~mm}$ ) with rounded edges is laid on the insulating coating, and the potential of this electrode is continuously increased until electrical breakdown occurs.

\section{Some data from actual practice}

The examples in Tables 6 to 13 are intended merely to indicate the order of magnitude of values anticipated in practice. 


\section{Data from actual practice}

Table 6: Potentials (voltages)

\begin{tabular}{|c|c|}
\hline Person, walking on rubber soles & up to \\
\hline $\begin{array}{l}\text { Person, walking with rubber soles } \\
\text { on a carpet }\end{array}$ & up to \\
\hline Transmission belt, speed 3 to $15 \mathrm{~m} \cdot \mathrm{s}^{-1}$ & up to \\
\hline $\begin{array}{l}\text { Surface of a light fuel in a large } \\
\text { container that has been filled rapidly }\end{array}$ & up to \\
\hline $\begin{array}{l}\text { Flange on a glass line when } \\
\text { toluene flows through line }\end{array}$ & up to \\
\hline Flange on a steam ejector & up to \\
\hline $\begin{array}{l}\text { Roll of paper, unwinding at a rate } \\
\text { exceeding } 10 \mathrm{~m} \cdot \mathrm{s}^{-1}\end{array}$ & up to \\
\hline
\end{tabular}

Table 7: Capacitances to ground

\begin{tabular}{llr}
\hline & \multicolumn{2}{c}{ pF } \\
Single screws (bolts) & approx. & 1 \\
Flange, $100 \mathrm{~mm}$ nominal width & approx. & 12 \\
Isolated cyclone (height $=1 \mathrm{~m}$, & & \\
$\quad$ dia. $=1 \mathrm{~m}$ ) & & $30-50$ \\
Person & approx. & $100-200$ \\
Road tanker & & 1000
\end{tabular}

Table 8: Leakage resistances (discharge resistances)

\begin{tabular}{|c|c|}
\hline & $\Omega$ \\
\hline Conductive footwear & $10^{4}-10^{8}$ \\
\hline Insulating footwear & $10^{8}$ to $10^{15}$ \\
\hline Human skin, dry & $10^{4}$ \\
\hline wet & $10^{2}$ \\
\hline PVC floor without conductive additives & $10^{11}$ \\
\hline Concrete floor, dry & $10^{6}$ \\
\hline Wooden floor, untreated, dry & $10^{7}$ \\
\hline Flange on glass line & $10^{11}-10^{13}$ \\
\hline
\end{tabular}

Table 9: Resistivities of certain solids

\begin{tabular}{llr} 
Metals & & \multicolumn{2}{c}{$\Omega \cdot \mathrm{m}$} \\
Wood, dry & $10^{-5}$ to $10^{-8}$ \\
Powders & approx. & $5 \cdot 10^{9}$ \\
Window glass & up to approx. & $10^{13}$ \\
Pyrex glass & approx. & $10^{11}$ \\
Plexiglass & approx. & $6 \cdot 10^{11}$ \\
PVC & approx. & $2 \cdot 10^{12}$ \\
Teflon & approx. & $2 \cdot 10^{13}$ \\
Makrofol (insulating foil) & approx. & $2 \cdot 10^{13}$ \\
& & $10^{15}$
\end{tabular}

Table 10: Resistivities of certain solvents

see page 29

Table 11: Specific charge of dusts after pneumatic transfer

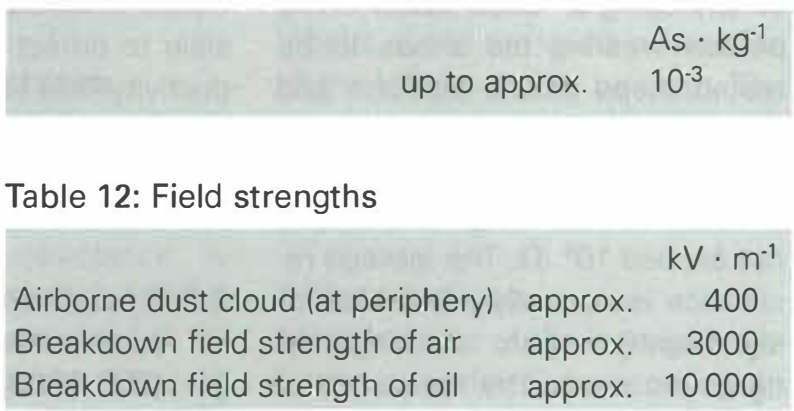

Table 13: Minimum ignition energies in air

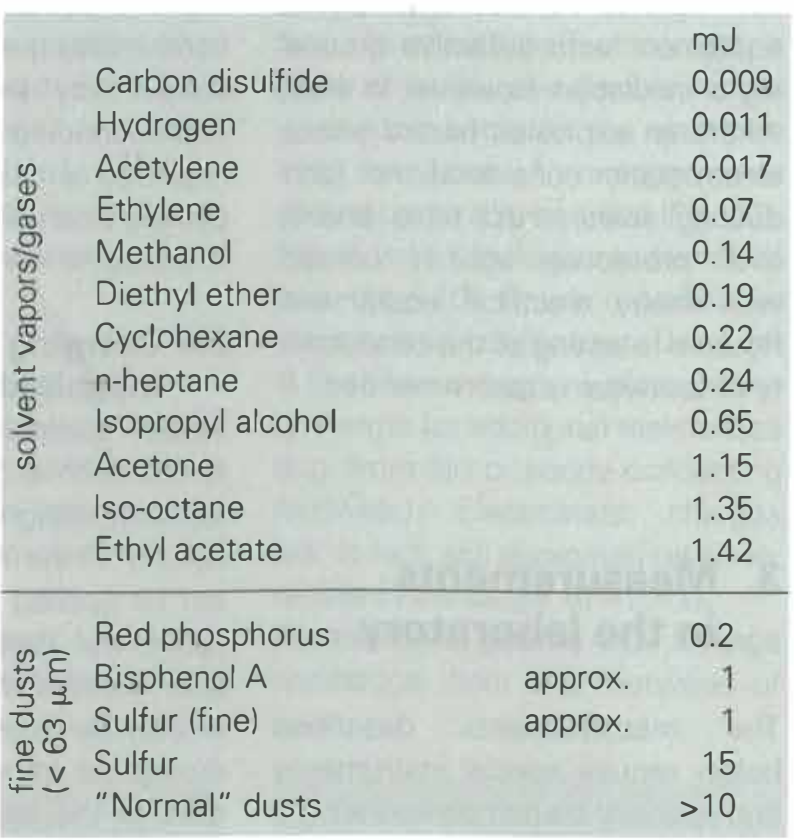

Table 14: Sensitivity of humans to discharges of static electricity

$\begin{array}{ccl}\text { Energy: } & 0.002 \mathrm{~J} & \text { perceptible } \\ 0.010 \mathrm{~J} & \text { distinctly perceptible } \\ 0.25 \mathrm{~J} & \text { severe shock } \\ 10 & \mathrm{~J} & \text { possibly lethal }\end{array}$




\section{Data from actual practice}

Table 10: Resistivities of certain solvents

(See also Practical Section, 2.1.2, corresponds to Tables 1 and 2, pages 6 and 7)

\section{Liquids with low}

and middle conductivity

$\left(\rho_{D}>10^{9} \Omega \cdot \mathrm{m}\right)$

In this category we find aliphatic and aromatic hydrocarbons, ethers, esters of higher acids, $C_{1}$ derivatives

\begin{tabular}{|c|c|}
\hline \multicolumn{2}{|l|}{ iqu } \\
\hline Carbon disulfide & $10^{16} \Omega \cdot m$ \\
\hline Carbon tetrachloride & $10^{15} \Omega \cdot m$ \\
\hline Diesel oil & $10^{13} \Omega \cdot \mathrm{m}$ \\
\hline Gasoline & \\
\hline Cyclohexane & \\
\hline $\begin{array}{l}\text { Benzene, toluene, xylen } \\
\text { Mesitylene }\end{array}$ & \\
\hline Diethyl ether & \\
\hline 1,4-dioxane & $10^{12} \Omega \cdot m$ \\
\hline Anisole & $10^{11} \Omega \cdot \mathrm{m}$ \\
\hline Stearic acid di & $r 10^{10} \Omega \cdot r$ \\
\hline
\end{tabular}

\section{Liquids* with high}

conductivity $\left(\rho_{D}<10^{9} \Omega \cdot \mathrm{m}\right)$

Examples of this category are hydrocarbons with "polar" groups such as alcohols, aldehydes, ketones, acids, esters, nitriles, amides, amines, nitro compounds

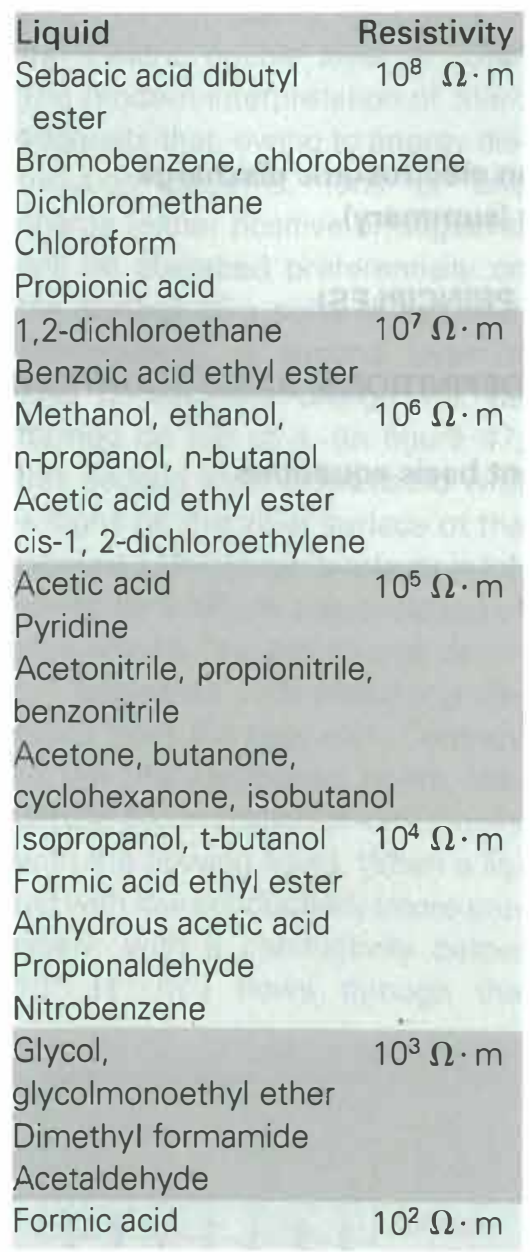

* NB: All values stated refer to pure liquids and are rounded to the nearest power of 10. Exact values will be found in $|2|$. 


\section{Fundamentals}

\section{Contents}

1. THE GENERATION OF STATIC CHARGES 31

2. CHARGE RELAXATION AND DISCHARGE 32

2.1 Characterization of different types of discharge 32

2.1.1 Spark discharge 32

2.1.2 Brush discharge 33

2.1.3 Corona discharge 33

2.1.4 Propagating brush discharge 33

2.1.5 Lightning-like discharge $\quad 33$

2.1.6 Cone discharge 33

2.2 The hazard created by an electrostatic discharge 33

2.3 Electrostatic discharges (summary) 34

3. PROTECTIVE MEASURES (FIVE PRINCIPLES) 35

4. COMMONLY USED SYMBOLS, DEFINITIONS, BASIC EQUATIONS 36

$\begin{array}{lll}4.1 & \text { Symbols and units } & 36\end{array}$

4.2 Definitions and important basic equations 36 


\section{Fundamentals}

\section{The generation of static charges}

Whenever two dissimilar materials come in contact, a transfer of electrons from one material to the other takes place. As a result, one material acquires an excess of negative charges and the other material an equal excess of positive charges. If the two materials are now separated, each will possess excess charge; electrostatic charging has taken place. If both materials are conductors (e.g. 2 metals), the high conductivity allows an equalization of charges to take place along the contact surface during the separation so that no measurable excess charge is present on complete separation. Measurable charges will thus be created only if one of the materials involved is a non-conductor. The human body may be regarded as a conductor in such processes. All solids having a surface resistance (measured according to DIN IEC 60093) higher than $10^{11} \Omega$ are regarded as non-conduc-

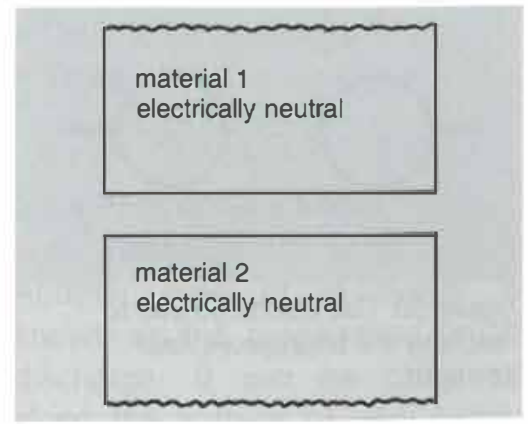

Figure 44: Two dissimilar materials before contact tive. (For examples of separation charges, see Part 1 of this booklet, pages 5 and 6.)

The charging mechanism in a flowing liquid is different from the charging process during the contact of solids, since fluids can be regarded as (very weak) electrolytes with free charge carriers (ions). For the transfer of charges between liquids and solids, this fact was already recognized by Helmholtz when he formulated the theory of the electric double layer in 1879. The modern interpretation of Stern suggests that, owing to energy distribution patterns, ions of one charge (either positive or negative) will be absorbed preferentially on the surface of a solid object, and, subsequently, a second layer of ions of opposite charge will be formed on top of it. (In figure 47. this second layer is indicated with + signs on the inner surface of the pipeline.) This secondary layer is followed by a diffuse accumulation of ions whose "excess charge density" decreases with increasing distance from the pipe wall. Contrary to the first-mentioned layers, this diffuse accumulation of ions moves with the flowing liquid. When a liquid with low conductivity (more precisely: with a conductivity below $10^{-9} \Omega^{-1} \cdot \mathrm{m}^{-1}$ ) flows through the

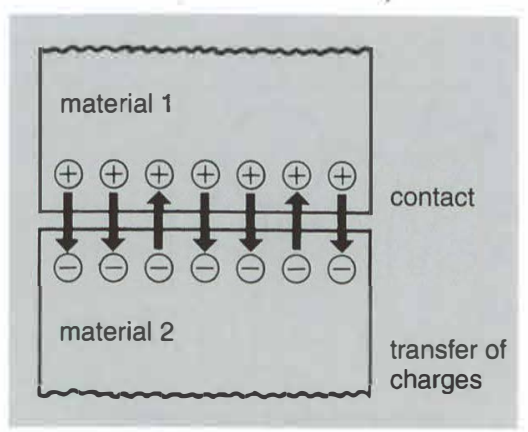

Figure 45: Two dissimilar materials in contact: transfer of charges pipe, only the diffuse accumulation of ions will move along with the liquid. As a consequence, the liquid flowing into the receiver will be charged. In the case of a conductive liquid, a balance of charges will be reached while the liquid is still in the pipe.

Whenever particles of dusts or fluids move in a gas phase, the generation of charges must be expected regardless of their conductivity. A special type of charge separation takes place when a liquid (especially a polar one) is atomized (Lenard effect). In the case of water, for example, negative charge will predominate among the small and extremely small droplets, while the larger droplets will mostly carry a positive charge. Details can be found in the literature.

\section{Electrostatic induction}

A special phenomenon involves the formation of charges by electrostatic induction. Charge displacement occurs in insulated conductors when they approach charged objects closely. If charges of one polarity can flow away at this instant, and good insulation is subsequently restored, then the conductor itself will have acquired a charge when it is removed from the vicinity of the charged object.

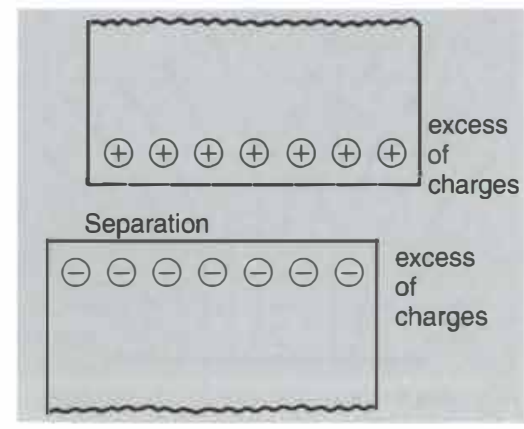

Figure 46: Separation of two dissimilar materials: equal excess of charges with positive and negative charges respectively 


\section{Charge relaxation and discharge}

When the charging process stops, the excess charges will start to balance themselves. This charge relaxation process follows an exponential course and depends on the resistance (which in turn depends on voltage) of the charged material or on its leakage resistance to ground. For plastics, the charge relaxation process can take hours or even days. During this time, important changes can occur in the vicinity of the charged surface. Example (see figures 48, 49): a charge has accumulated on a surface. A grounded conductive sphere is brought up, the electric field undergoes changes and, in particular, the field strength near the sphere increases. On further approach of the sphere, the critical field strength, i.e. the breakdown field strength (for air approx. $3 \mathrm{MV} \cdot \mathrm{m}^{-1}$ ) will be reached, and a gas discharge takes place. This discharge becomes possible because the free electrons that are always present in air are sufficiently accelerated by the electric field to ionize air molecules. Since the breakdown field strength of gases is significantly lower than that of liquid or solid non-conduc-

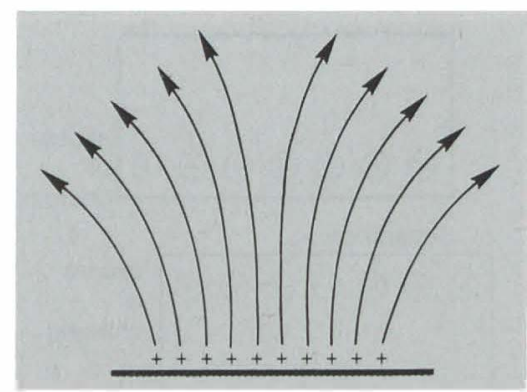

Figure 48: Charged surface with electrical field

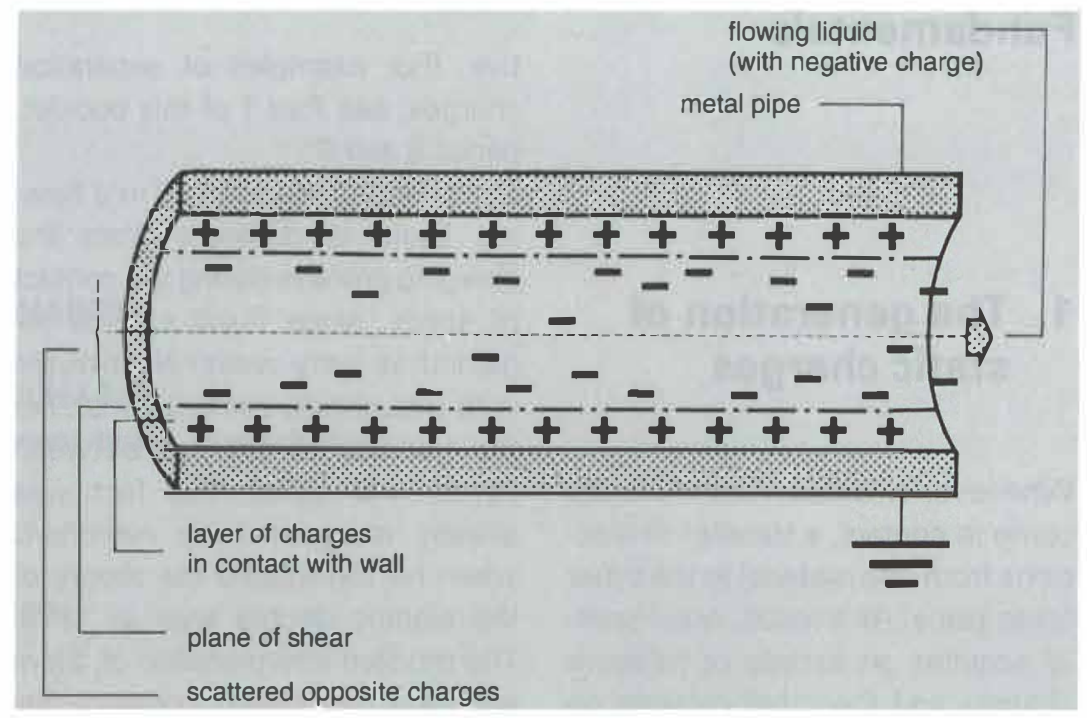

Figure 47: Charging mechanism in a flowing liquid (electric double layer)

tors, gas discharges are by far the most important sources of hazard.

\subsection{Characterization of different types of discharges}

Depending on the geometry of the arrangement, on the materials involved, and on certain other conditions, six different types of discharge are distinguished:

- Spark discharge

- Brush discharge

- Corona discharge

- Propagating brush discharge

- Lightning-like discharge

- Cone discharge

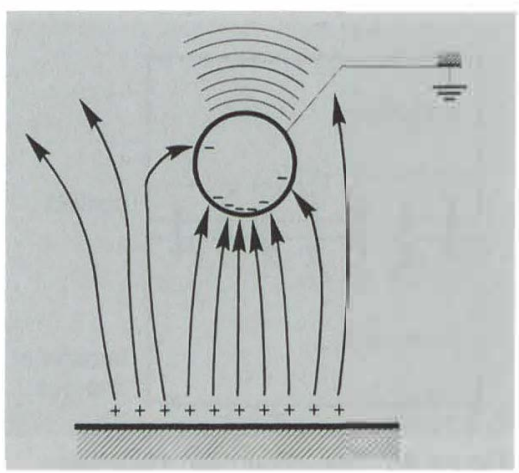

Figure 49: Charged surface: influence of a grounded conductive sphere on the electrical field
Characterizations of the different types of discharge are illustrated by sketches of the model experiments used to demonstrate them.

\subsubsection{Spark discharge}

- Discharge in a virtually homogeneous field

- Discharge between two conductors

- Luminous phenomenon bridges the gap between the conductors

- Discharge occurs in a sudden burst

- Typical radius of curvature of the conductors: $\geq 5 \mathrm{~cm}$

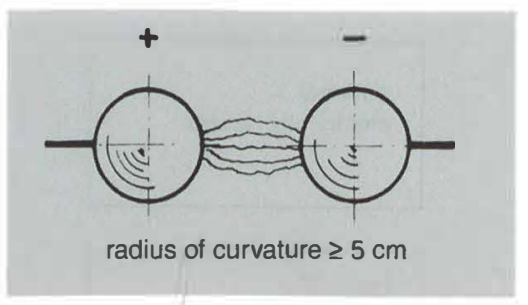

Figure 50: Gas discharge due to reaching the breakdown field strength 


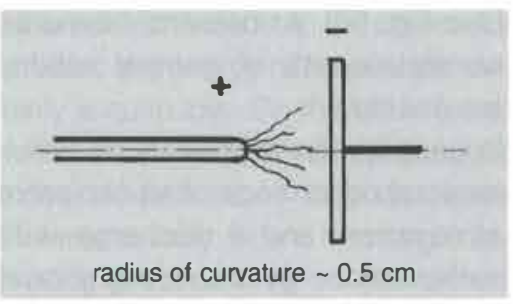

Figure 51: Brush discharge

\subsubsection{Brush discharge}

- Discharge in the inhomogeneous field

- Discharge between a conductor and a charged conductive or nonconductive surface or a charged cloud

- Luminous phenomenon is emitted from the conductor at the location of the highest field strength and fails to bridge the gap

- Several discharges in rapid succession give the overall impression of a "brush"

- Typical radius of curvature: approx. $0.5 \mathrm{~cm}$

\subsubsection{Corona discharge}

- Discharge in the extremely inhomogeneous field

- Discharge between a conductive point and a charged conductive or non-conductive surface or a charged cloud

- Luminous phenomenon in the shape of a "crown" (corona) immediately around the conductive point and nowhere else

- Continuous discharge

- Typical radius of curvature: $<1 \mathrm{~mm}$

\subsubsection{Propagating brush discharge}

Another type of discharge is known as the propagating brush discharge. It can be observed along the surface of very highly charged non-conductive surfaces and is accompanied by luminous effects.

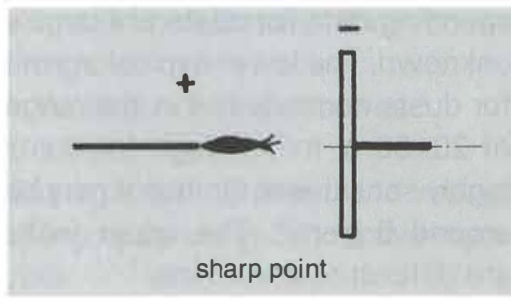

Figure 52: Corona discharge

\subsubsection{Lightning-like discharge}

It has never been proved beyond doubt that this type of discharge can occur in industrial operations. It is thought that - similar to the phenomenon observed in nature - a lightning-like discharge could occur, e.g. between a highly charged dust cloud in a large silo and the wall of the silo, or perhaps even between two dust clouds of different polarity created by sedimentation in a tall silo. According to the present state of knowledge, this type of discharge cannot occur in vessels smaller than $60 \mathrm{~m}^{3}$ or in silos of any height when the diameter is less than 3 meters.

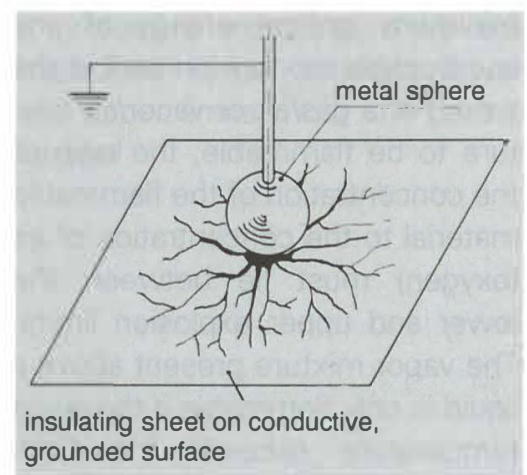

Figure 53: Propagating brush discharge

\subsubsection{Cone discharge}

This type of discharge has been observed when loading highly-insulating powder into silos and containers. It takes the form of discharge channels running radially along the surface of the bulk product.

\subsection{The hazard created by an electrostatic discharge}

An electrostatic discharge is capable of causing ignition when the energy released is greater than the

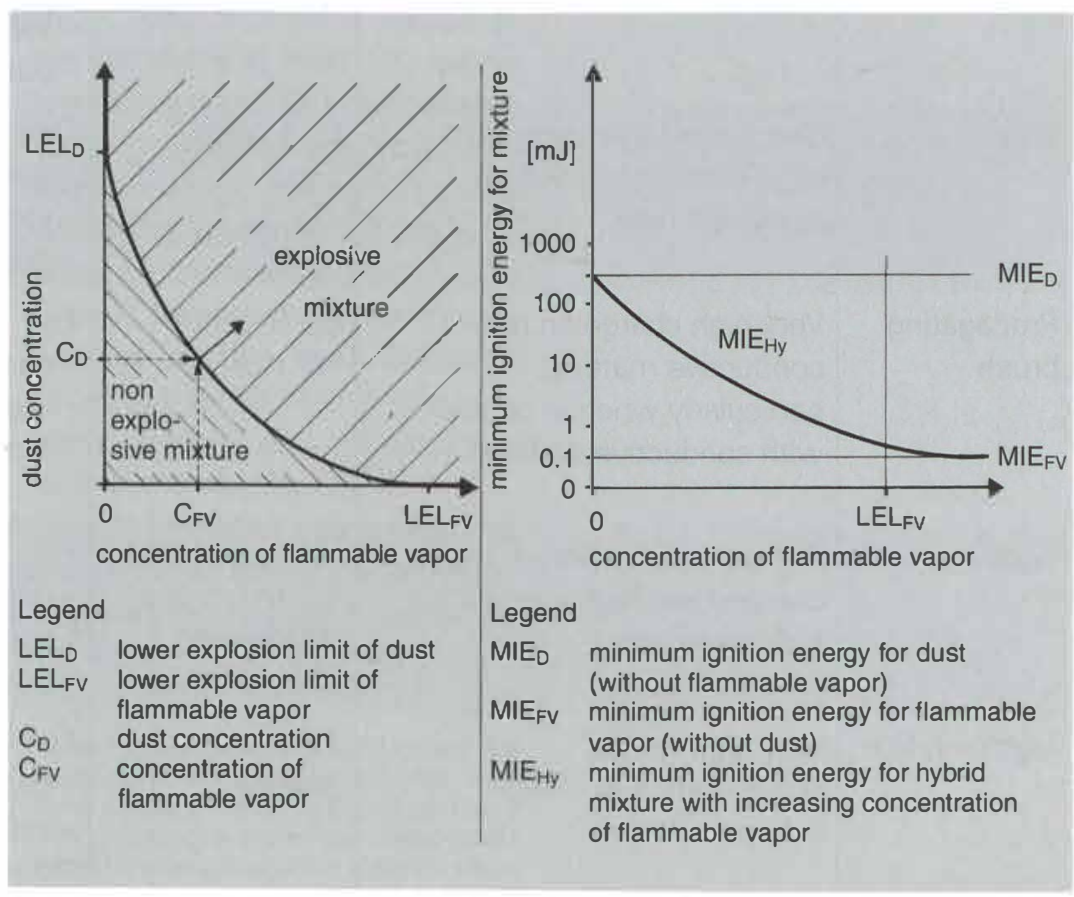

Figure 54: Explosion range of hybrid mixtures of hybrid mixtures
Figure 55: Minimum ignition energy $M I E_{O L}$ 
minimum ignition energy of any combustible mixture present at the time. For a gas/air or vapor/air mixture to be flammable, the ratio of the concentration of the flammable material to the concentration of air (oxygen) must lie between the lower and upper explosion limits. The vapor mixture present above a liquid is only flammable if the liquid temperature exceeds the flash point. However, it must be noted that, owing to their low heat capacity, the temperature of liquid droplets in aerosols can rise very rapidly above the flash point. Although the explosion limits are known for gas mixtures, the corre- sponding data for dusts are largely unknown. The lower explosion limit for dusts normally lies in the range of 20-50 $\mathrm{g} \cdot \mathrm{m}^{-3}$, though for dusts highly sensitive to ignition it may be around $5 \mathrm{~g} \cdot \mathrm{m}^{-3}$. The upper limits are difficult to determine.

Hybrid mixtures (i.e. mixtures of combustible dust, flammable gas or vapor and air) may be flammable even if the concentrations of the dust and the vapor or gas are below the lower explosion limit applicable to the individual component. The minimum ignition energy of a hybrid mixture lies somewhere between the minimum ignition energy of the dust and that of the gas or vapor (see Fig. 55). At present, however, no statements of general validity are possible.

In general, the probability of simultaneous occurrence of an explosive atmosphere and a discharge with sufficient energy to cause ignition is rather low. It is therefore not uncommon to find operations hazarded by electrostatic charges running for years without difficulty before an accident suddenly occurs.

The quantity of energy released during discharge is dependent, among other things, on the type of discharge. The corona, or point, discharge is the least hazardous since the discharge begins when the point is still at a con-

\subsection{Electrostatic discharges (summary)}

Table 15: Electrostatic discharges

\begin{tabular}{|c|c|c|c|c|}
\hline $\begin{array}{l}\text { Type of } \\
\text { discharge }\end{array}$ & Conditions for occurrence & $\begin{array}{l}\text { Typical values } \\
\text { of released } \\
\text { energy }\end{array}$ & Incendivity & $\begin{array}{l}\text { Most important } \\
\text { protection measures } \\
\text { against ignition hazards }\end{array}$ \\
\hline Spark & $\begin{array}{l}\text { Ungrounded, conductive } \\
\text { object }\end{array}$ & $\begin{array}{l}\text { Up to approx. } \\
10^{3} \mathrm{~mJ}\end{array}$ & $\begin{array}{l}\text { For: } \\
\text { - gases } \\
\text { - vapors } \\
\text { - dusts }\end{array}$ & Ground \\
\hline Brush & $\begin{array}{l}\text { Conductive electrode with } \\
\text { large radius of curvature } \\
\text { in electric field }\end{array}$ & $\begin{array}{l}\text { Up to max. } \\
5 \mathrm{~mJ}\end{array}$ & $\begin{array}{l}\text { Only for: } \\
\text { - gases } \\
\text { - vapors } \\
\text { - dusts* }\end{array}$ & $\begin{array}{l}\text { In the presence of } \\
\text { flammable gases and } \\
\text { vapors, avoid charging } \\
\text { of the non-conductor }\end{array}$ \\
\hline $\begin{array}{l}\text { Propagating } \\
\text { brush }\end{array}$ & $\begin{array}{l}\text { Very high charge on non- } \\
\text { conductive material, } \\
\text { particularly when in contact } \\
\text { with conductive surface }\end{array}$ & $\begin{array}{l}\text { Up to approx. } \\
10^{4} \mathrm{~mJ}\end{array}$ & $\begin{array}{l}\text { For: } \\
\text { - gases } \\
\text { - vapors } \\
\text { - dusts }\end{array}$ & $\begin{array}{l}\text { Avoid combination } \\
\text { conductive/non- } \\
\text { conductive and reduce } \\
\text { high charging of non- } \\
\text { conductor }\end{array}$ \\
\hline Cone & $\begin{array}{l}\text { Rapid accumulation of highly } \\
\text { charged and highly insulating } \\
\text { bulk material }\end{array}$ & $\begin{array}{l}\text { Up to approx. } \\
10^{3} \mathrm{~mJ} \text { in one } \\
\text { discharging } \\
\text { step }\end{array}$ & $\begin{array}{l}\text { For: } \\
\text { - gases } \\
\text { - vapors } \\
\text { - dusts }\end{array}$ & $\begin{array}{l}\text { Reduce charging of bulk } \\
\text { material }\end{array}$ \\
\hline Lightning-like & $\begin{array}{l}\text { Very high spatial } \\
\text { accumulation of charge } \\
\text { in large volumes }\end{array}$ & $\begin{array}{l}10^{4} \mathrm{~mJ} \text { and } \\
\text { greater }\end{array}$ & $\begin{array}{l}\text { For: } \\
\text { - gases } \\
\text { - vapors } \\
\text { - dusts }\end{array}$ & $\begin{array}{l}\text { Reduce charging of non- } \\
\text { conductor, or restrict } \\
\text { diameter to } \mathrm{D} \leq 3 \mathrm{~m}\end{array}$ \\
\hline
\end{tabular}

*Extremely sensitive dusts (<3 mJ) 
siderable distance from the object. As a result, the energy released momentarily is quite low. On the other hand, when two large spheres are brought close to each other, they discharge instantaneously (spark discharge) releasing practically the entire stored energy at once to provide a potential ignition source for a gas mixture or a dust. The energy release of brush discharges lies somewhere between these extremes.

\section{Protective measures (five principles)}

From the fundamentals explained in the two previous sections, five principles for the application of protective measures are derived. In industrial operations, these principles have to be applied selectively, and commensurate to the prevailing circumstances. The most common applications are described in the practical section (pages 6-23).

1st principle: Ground all conductors.

A large number of hazards caused by electrostatic charging can be eliminated by careful grounding of all conductors.

- Ground all items of equipment.

- Interconnect building structures with conductors.

- Ground isolated metal parts, e.g. flanges and metal sheeting on insulation material, on plastic pipelines, cyclones, etc.

- Place metal drums on conductive floors, or connect to ground.

2nd principle: Ground personnel. The human body, which is a conductor with regard to static electricity, can carry charges.
- Install conductive floor coverings.

- Wear conductive footwear.

3rd principle: Prevent and reduce charging by using conductive materials

- If possible, use aqueous solutions, alcohols, polar solvents.

- If possible, avoid highly insulating plastic containers and bags.

- Use conductive drive belts.

- Use conductive pipes.

- Use conductive filter materials for dust filters if the presence of flammable vapors is suspected.

4th principle: Keep velocities low

- Limit the flow velocity of liquids and gases containing dust and liquid particles.

- Avoid turbulence in chargeable liquids.

5th principle: Avoid explosive mixtures and aerosols

- Remove gases, vapors, and dusts by suction at the source.

- Work with flammable liquids at temperatures at least $5^{\circ} \mathrm{C}$ below their flash point ${ }^{15}$. (If combustible dusts or powders are present simultaneously, the phenomena explained in section 2.2, page 33 must be considered.)

- Charge flammable liquids to vessels by suction, and discharge (blow out) by nitrogen pressure.

- Work under inert atmosphere with flammable liquids.

It should be noted that working at concentrations above the upper explosion limit cannot be regarded as

\footnotetext{
${ }^{15}$ At temperatures at least $5^{\circ} \mathrm{C}$ below the flash point, no explosive vapor/air mixtures will be formed. The margin of $5^{\circ} \mathrm{C}$ is intended to cover the scatter of flash point determinations. In addition, possible variations in product quality must be considered: they can cause flash point variations of several ${ }^{\circ} \mathrm{C}$.
}

a protective measure, since the hazardous range between lower and upper limits must still be traversed! 


\section{Commonly used symbols, definitions, basic equations}

\subsection{Symbols and units}

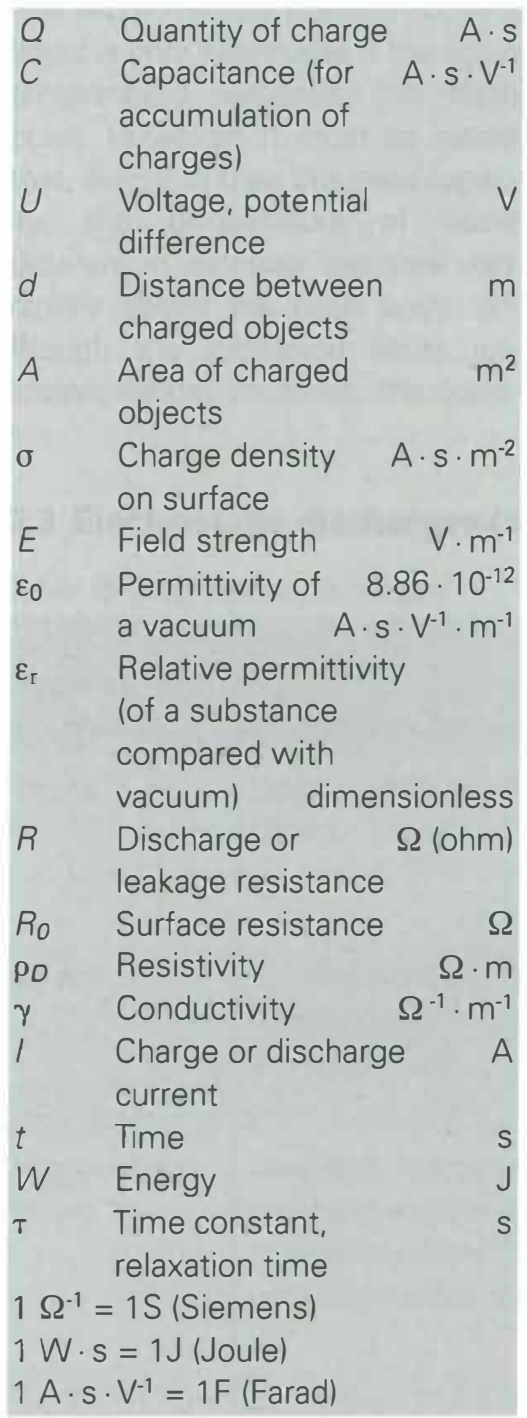

\subsection{Definitions and important basic equations}

Charge:

general $Q=\int /(t) \cdot d t$

for constant current,

$\mathrm{I}(\mathrm{t})=\mathrm{I}=$ constant:

$\mathrm{Q}=1 \cdot \mathrm{t}$

Charge density: charge per unit of area

$\sigma=\frac{d Q}{d A}$

Field strength:

general $\vec{E}=$-grad $U$

for a parallel plate capacitor (con-

stant field strength), the following equation applies:

$E=\frac{U_{12}}{d_{12}}$

$U_{12}$ potential difference between points 1 and 2

$d_{12}$ distance between these points 1 and 2

Relation between charge density $\sigma$ on the surface of a conductor and the field strength prevailing there:

$\sigma=\varepsilon_{0} \cdot E$

Since the field strength in air is limited to roughly $3 \mathrm{MV} \cdot \mathrm{m}^{-1}$ (breakdown field strength), the maximum charge density $\sigma_{\max }$ on the surface of a conductor in air is:

$\sigma_{\max }=8.86 \cdot 10^{-12} \frac{\mathrm{A} \cdot \mathrm{s}}{\mathrm{V} \cdot \mathrm{m}} \cdot 3 \cdot 10^{6} \frac{\mathrm{V}}{\mathrm{m}}$

$=2.66 \cdot 10^{-5} \frac{\mathrm{A} \cdot \mathrm{S}}{\mathrm{m}^{2}}$

For a parallel plate capacitor with plate area $A$, potential difference $U$ and plate distance $d$, the following applies:

$\sigma=\frac{Q}{A}=\varepsilon_{0} \cdot E=\varepsilon_{0} \cdot \frac{U}{d}$

$Q=\frac{\varepsilon_{0} \cdot U \cdot A}{d}=\frac{\varepsilon_{0} \cdot A}{d} U$
Capacitor: two conductors isolated from each other.

Capacitance: ability of a capacitor to store electrical energy

$C=\frac{Q}{U}$

Consequently, the capacitance of a parallel plate capacitor is:

$C=\frac{Q}{U}=\frac{\varepsilon_{0} \cdot A \cdot U}{d} \cdot \frac{1}{U}=\frac{\varepsilon_{0} \cdot A}{d}$

In practice, capacitances are mostly given in $\mathrm{pF}$ (picofarad)

$1 \mathrm{pF}=10^{-12} \mathrm{~F}$

$1 \mathrm{nF}=10^{-9} \mathrm{~F}$

$1 \mu \mathrm{F}=10^{-6} \mathrm{~F}$

The energy stored in a capacitor is $W=\frac{1}{2} C \cdot U^{2}=\frac{1}{2} Q \cdot U$

Example: An isolated flange of nominal width $100 \mathrm{~mm}$ is charged to a potential of $10,000 \mathrm{~V}$. The capacitance of the flange is: $12 \mathrm{pF}$. The stored energy is thus:

$$
\begin{aligned}
W & =\frac{1}{2} \cdot C \cdot U^{2}=\frac{1}{2} \cdot 12 \cdot \mathrm{pF} \cdot(10,000 \mathrm{~V})^{2} \\
& =\frac{1}{2} \cdot 12 \cdot 10^{-12} F \cdot 10^{8} \mathrm{~V}^{2} \\
& =6 \cdot 10^{-4} \mathrm{~J}=0.6 \mathrm{~mJ}
\end{aligned}
$$

Time constant: $\tau=R \cdot C$

During this time the potential is reduced by a factor e, i.e. to approx. $37 \%$ of its original value.

Discharge time: $5 \tau$

During this time, the potential is reduced to approx. $1 \%$ of its original value.

\section{Example:}

An isolated cyclone has a leakage resistance to ground of $10^{12} \Omega$. Its capacitance is $40 \mathrm{pF}$.

$\tau=R \cdot C=10^{12} \Omega \cdot 40 \mathrm{pF}$

$=10^{12} \cdot 40 \cdot 10^{-12} \mathrm{~s}=40 \mathrm{~s}$ 


\section{ANNEX B}

Discharge time:

$5 \cdot \tau=5 \cdot 40 \mathrm{~s}=200 \mathrm{~s}$

Detailed presentations of definitions and basic equations can be found in:

Lüttgens G., Glor M., "Understanding and Controlling Static Electricity", Expert Verlag, D-71139 Ehningen bei Böblingen, 1989. 


\section{Permissibility of different types of package for flammable liquids and combustible dusts}

Contents

1. BAGS 39

1.1 Paper bag 39

Paper bag coated on the inner surface
with an insulating layer

1.3 Paper bag made from different layers of paper and insulating plastic material with the inner
and outer layer made from paper

$1.4 \quad$ Plastic bag 42

1.5 Plastic bag with antistatic treatment 43

1.6 Plastic bag made conductive by the addition of carbon black 44

1.7 Aluminum bag 45

2. DRUMS 46

2.1 Metal drum 46

2.2 Metal drum with thin ( $<2 \mathrm{~mm}$ ) insulating coating or paint (inside and/or outside) 47

2.3 Metal drum with plastic liner 48

2.4 Metal drum with plastic liner with antistatic treatment 49

2.5 Metal drum with plastic liner made conductive

2.6 Metal drum with internal plastic container and small

2.7 Cardboard drum with or without a thin (<2 $\mathrm{mm})$ insulating coating on one side $\quad 52$

2.8 Cardboard drum with plastic liner 53

2.9 Cardboard drum with plastic liner with antistatic treatment 54

2.10 Cardboard drum with conductive liner 55

2.11 Fiber drum or plastic drum 55

2.12 Fiber drum or plastic drum with plastic liner 56

2.13 Fiber drum or plastic drum with conductive liner 56

3. CONTAINERS 57

3.1 Metal container 57

3.2 Plastic container with metal shielding in the form of
metal plates or a metal grid

4. $\mathrm{FIBC}$ (BIG BAGS) 59

4.1 Flexible intermediate bulk container (FIBC) Type A 59

4.2 Flexible intermediate bulk container (FIBC) Type B 60

4.3 Flexible intermediate bulk container (FIBC) Type C 61

4.4 Flexible intermediate bulk container (FIBC) Type D 63 


\section{Bags}

\section{Package}

\subsection{Paper bag}

\section{Hazards:}

- In a very dry atmosphere and/or in case of high separation speed (> $1 \mathrm{~m} / \mathrm{s}$ ) brush discharges may occur.
- If the bag becomes wet and is not in contact with ground, spark discharges may occur.

\begin{tabular}{|c|c|c|c|c|}
\hline Product & $\begin{array}{l}\text { Explosive } \\
\text { atmosphere in } \\
\text { the environment }\end{array}$ & Permitted & $\begin{array}{l}\text { Requirements and } \\
\text { limits during filling } \\
\text { and emptying }\end{array}$ & Remarks \\
\hline $\begin{array}{l}\text { non-combustible } \\
\text { powder }\end{array}$ & none & yes & none & $\begin{array}{l}\text { consider hazards } \\
\text { of electric shock }\end{array}$ \\
\hline \multirow{2}{*}{$\begin{array}{l}\text { combustible } \\
\text { powder }\end{array}$} & none & \multirow[t]{2}{*}{ yes } & \multirow{2}{*}{$\begin{array}{l}\text { - filling and emptying } \\
\text { by gravity } \\
\text { - volume } \leq 50 \text { I }\end{array}$} & \\
\hline & combustible powder & & & \\
\hline $\begin{array}{l}\text { non-combustible } \\
\text { powder }\end{array}$ & \multirow{2}{*}{$\begin{array}{l}\text { flammable gas } \\
\text { or vapor } \\
\text { or } \\
\text { hybrid mixture }\end{array}$} & \multirow[t]{2}{*}{ yes } & \multirow{2}{*}{$\begin{array}{l}\text { - filling and emptying } \\
\text { by gravity } \\
\text { - volume } \leq 50 \text { I } \\
\text { - contact to ground via } \\
\text { the operator or conductive } \\
\text { surface of the grounded } \\
\text { equipment }\end{array}$} & \\
\hline $\begin{array}{l}\text { combustible } \\
\text { powder }\end{array}$ & & & & \\
\hline $\begin{array}{l}\text { powder with } \\
\text { flammable } \\
\text { solvent }\end{array}$ & any & yes & $\begin{array}{l}\text { - filling and emptying } \\
\text { by gravity } \\
\text { - volume } \leq 50 \text { I } \\
\text { - contact to ground via } \\
\text { the operator or conductive } \\
\text { surface of the grounded } \\
\text { equipment }\end{array}$ & \\
\hline
\end{tabular}




\section{Package}

1.2 Paper bag coated on the inner surface with an insulating layer

With the following specifications:

- thickness of the insulating layer is not greater than $0.2 \mathrm{~mm}$
Hazards:

- In a very dry atmosphere and/or in case of high separation speed (> $1 \mathrm{~m} / \mathrm{s}$ ) brush discharges may occur.
- If the insulating layer becomes detached from the paper, brush discharges may occur.

- If the bag becomes wet and is not in contact with ground, spark discharges may occur.

\begin{tabular}{|c|c|c|c|c|}
\hline Product & $\begin{array}{l}\text { Explosive } \\
\text { atmosphere in } \\
\text { the environment }\end{array}$ & Permitted & $\begin{array}{l}\text { Requirements and } \\
\text { limits during filling } \\
\text { and emptying }\end{array}$ & Remarks \\
\hline $\begin{array}{l}\text { non-combustible } \\
\text { powder }\end{array}$ & none & yes & none & $\begin{array}{l}\text { consider hazards } \\
\text { of electric shock }\end{array}$ \\
\hline \multirow{2}{*}{$\begin{array}{l}\text { combustible } \\
\text { powder }\end{array}$} & none & \multirow[t]{2}{*}{ yes } & \multirow{2}{*}{$\begin{array}{l}\text { - filling and emptying } \\
\text { by gravity } \\
\text { - volume } \leq 50 \text { I }\end{array}$} & \\
\hline & combustible powder & & & \\
\hline $\begin{array}{l}\text { non-combustible } \\
\text { powder }\end{array}$ & \multirow{2}{*}{$\begin{array}{l}\text { flammable gas } \\
\text { or vapor } \\
\text { or } \\
\text { hybrid mixture }\end{array}$} & \multirow[t]{2}{*}{ yes } & \multirow{2}{*}{$\begin{array}{l}\text { - filling and emptying } \\
\text { by gravity } \\
\text { - volume } \leq 50 \text { I } \\
\text { - contact to ground via } \\
\text { the operator or conductive } \\
\text { surface of the grounded } \\
\text { equipment }\end{array}$} & \multirow[t]{2}{*}{$\begin{array}{l}\text { insulating layer must not } \\
\text { become detached from } \\
\text { the paper }\end{array}$} \\
\hline $\begin{array}{l}\text { combustible } \\
\text { powder }\end{array}$ & & & & \\
\hline $\begin{array}{l}\text { powder with } \\
\text { flammable } \\
\text { solvent }\end{array}$ & any & yes & $\begin{array}{l}\text { - filling and emptying } \\
\text { by gravity } \\
\text { - volume } \leq 50 \text { I } \\
\text { - contact to ground via } \\
\text { the operator or conductive } \\
\text { surface of the grounded } \\
\text { equipment }\end{array}$ & $\begin{array}{l}\text { insulating layer must not } \\
\text { become detached from } \\
\text { the paper }\end{array}$ \\
\hline
\end{tabular}




\section{Package}

\subsection{Paper bag made from different layers of paper and insulating plastic material} with the inner and outer layer made from paper

\section{Hazards:}

- In a very dry atmosphere and/or in case of high separation speed (> $1 \mathrm{~m} / \mathrm{s}$ ) brush discharges may occur.
- If the insulating layer becomes detached from the paper, brush discharges may occur.
- If the bag becomes wet and is not in contact with ground, spark discharges may occur.

\begin{tabular}{|c|c|c|c|c|}
\hline Product & $\begin{array}{l}\text { Explosive } \\
\text { atmosphere in } \\
\text { the environment }\end{array}$ & Permitted & $\begin{array}{l}\text { Requirements and } \\
\text { limits during filling } \\
\text { and emptying }\end{array}$ & Remarks \\
\hline $\begin{array}{l}\text { non-combustible } \\
\text { powder }\end{array}$ & none & yes & none & $\begin{array}{l}\text { consider hazards } \\
\text { of electric shock }\end{array}$ \\
\hline \multirow{2}{*}{$\begin{array}{l}\text { combustible } \\
\text { powder }\end{array}$} & none & \multirow[t]{2}{*}{ yes } & \multirow{2}{*}{$\begin{array}{l}\text { - filling and emptying } \\
\text { by gravity } \\
\text { - volume } \leq 50 \text { I }\end{array}$} & \\
\hline & combustible powder & & & \\
\hline $\begin{array}{l}\text { non-combustible } \\
\text { powder }\end{array}$ & \multirow{2}{*}{$\begin{array}{l}\text { flammable gas } \\
\text { or vapor } \\
\text { or } \\
\text { hybrid mixture }\end{array}$} & \multirow[t]{2}{*}{ yes } & \multirow{2}{*}{$\begin{array}{l}\text { - filling and emptying } \\
\text { by gravity } \\
\text { - volume } \leq 50 \text { I } \\
\text { - contact to ground via } \\
\text { the operator or conductive } \\
\text { surface of the grounded } \\
\text { equipment }\end{array}$} & \multirow[t]{2}{*}{$\begin{array}{l}\text { insulating layer must not } \\
\text { become detached from } \\
\text { the paper }\end{array}$} \\
\hline $\begin{array}{l}\text { combustible } \\
\text { powder }\end{array}$ & & & & \\
\hline $\begin{array}{l}\text { powder with } \\
\text { flammable } \\
\text { solvent }\end{array}$ & any & yes & $\begin{array}{l}\text { - filling and emptying } \\
\text { by gravity } \\
\text { - volume } \leq 50 \text { I } \\
\text { - contact to ground via } \\
\text { the operator or conductive } \\
\text { surface of the grounded } \\
\text { equipment }\end{array}$ & $\begin{array}{l}\text { insulating layer must not } \\
\text { become detached from } \\
\text { the paper }\end{array}$ \\
\hline
\end{tabular}




\section{Package}

\subsection{Plastic bag}

Hazard:

- During normal handling brush discharges may occur.

\begin{tabular}{|c|c|c|c|c|}
\hline Product & $\begin{array}{l}\text { Explosive } \\
\text { atmosphere in } \\
\text { the environment }\end{array}$ & Permitted & $\begin{array}{l}\text { Requirements and } \\
\text { limits during filling } \\
\text { and emptying }\end{array}$ & Remarks \\
\hline $\begin{array}{l}\text { non-combustible } \\
\text { powder }\end{array}$ & none & yes & none & $\begin{array}{l}\text { consider hazards } \\
\text { of electric shock }\end{array}$ \\
\hline \multirow{2}{*}{$\begin{array}{l}\text { combustible } \\
\text { powder }\end{array}$} & none & \multirow[t]{2}{*}{ yes } & \multirow{2}{*}{$\begin{array}{l}\text { - filling and emptying } \\
\text { by gravity } \\
\text { - volume } \leq 50 \text { I }\end{array}$} & \\
\hline & combustible powder & & & \\
\hline $\begin{array}{l}\text { non-combustible } \\
\text { powder }\end{array}$ & \multirow{2}{*}{$\begin{array}{l}\text { flammable gas } \\
\text { or vapor } \\
\text { or } \\
\text { hybrid mixture }\end{array}$} & \multirow[t]{2}{*}{ no } & & \\
\hline $\begin{array}{l}\text { combustible } \\
\text { powder }\end{array}$ & & & & \\
\hline $\begin{array}{l}\text { powder with } \\
\text { flammable } \\
\text { solvent }\end{array}$ & any & no & & \\
\hline
\end{tabular}




\section{Package}

\subsection{Plastic bag with antistatic treatment}

With the following specifications:

- Surface resistance below $10^{9} \Omega$ at $50 \%$ relative humidity (rh) and $23^{\circ} \mathrm{C}$ and above $10^{8} \Omega$ at $65 \%$ rh and $23^{\circ} \mathrm{C}$

or

- Surface resistance below $10^{11} \Omega$ at $30 \%$ rh and $23{ }^{\circ} \mathrm{C}$ and above $10^{8} \Omega$ at $65 \%$ rh and $23^{\circ} \mathrm{C}$
Hazards:

- The antistatic treatment of the plastic bag may become ineffective within a short period of time.

- The antistatic agent may be adsorbed by the product.

- In case of very dry conditions the surface resistance may be higher than the permissible upper limit.
- If the surface resistance does not lie within the required limits, brush or spark discharges may occur.

- If the bag becomes wet and is not in contact with ground, spark discharges may occur.

\begin{tabular}{|c|c|c|c|c|}
\hline Product & $\begin{array}{l}\text { Explosive } \\
\text { atmosphere in } \\
\text { the environment }\end{array}$ & Permitted & $\begin{array}{l}\text { Requirements and } \\
\text { limits during filling } \\
\text { and emptying }\end{array}$ & Remarks \\
\hline $\begin{array}{l}\text { non-combustible } \\
\text { powder }\end{array}$ & none & yes & none & $\begin{array}{l}\text { consider hazards } \\
\text { of electric shock }\end{array}$ \\
\hline \multirow{2}{*}{$\begin{array}{l}\text { combustible } \\
\text { powder }\end{array}$} & none & \multirow[t]{2}{*}{ yes } & \multirow{2}{*}{$\begin{array}{l}\text { - filling and emptying } \\
\text { by gravity } \\
\text { - volume } \leq 50 \text { I }\end{array}$} & \\
\hline & combustible powder & & & \\
\hline $\begin{array}{l}\text { non-combustible } \\
\text { powder }\end{array}$ & \multirow{2}{*}{$\begin{array}{l}\text { flammable gas } \\
\text { or vapor } \\
\text { or } \\
\text { hybrid mixture }\end{array}$} & \multirow[t]{2}{*}{ yes } & \multirow{2}{*}{$\begin{array}{l}\text { - filling and emptying } \\
\text { by gravity } \\
\text { - volume } \leq 50 \text { I } \\
\text { - contact to ground via } \\
\text { the operator or conductive } \\
\text { surface of the grounded } \\
\text { equipment }\end{array}$} & \\
\hline $\begin{array}{l}\text { combustible } \\
\text { powder }\end{array}$ & & & & \\
\hline $\begin{array}{l}\text { powder with } \\
\text { flammable } \\
\text { solvent }\end{array}$ & any & yes & $\begin{array}{l}\text { - filling and emptying } \\
\text { by gravity } \\
\text { - volume } \leq 50 \text { I } \\
\text { - contact to ground via } \\
\text { the operator or conductive } \\
\text { surface of the grounded } \\
\text { equipment }\end{array}$ & \\
\hline
\end{tabular}




\section{Package}

\subsection{Plastic bag made conductive by the addition of carbon black}

With the following specifications:

- Volume resistivity below $10^{4} \Omega \cdot \mathrm{m}$

\section{Hazards:}

- If the bag is not grounded, spark discharges may occur.

- Since, in practice, the probability is rather high that the bag is not grounded during filling or empty- ing when it is used in a self-supporting way, it is recommended to use such bags only in combination with grounded conductive drums.

\begin{tabular}{|c|c|c|c|c|}
\hline Product & \begin{tabular}{|l} 
Explosive \\
atmosphere in \\
the environment
\end{tabular} & Permitted & $\begin{array}{l}\text { Requirements and } \\
\text { limits during filling } \\
\text { and emptying }\end{array}$ & Remarks \\
\hline $\begin{array}{l}\text { non-combustible } \\
\text { powder }\end{array}$ & none & yes & none & $\begin{array}{l}\text { consider hazards } \\
\text { of electric shock }\end{array}$ \\
\hline \multirow{2}{*}{$\begin{array}{l}\text { combustible } \\
\text { powder }\end{array}$} & none & \multirow[t]{2}{*}{ yes } & \multirow{2}{*}{$\begin{array}{l}\text { - filling and emptying } \\
\text { by gravity } \\
\text { - volume } \leq 50 \text { I } \\
\text { - grounding required }\end{array}$} & \multirow{2}{*}{$\begin{array}{l}\text { only use in combination } \\
\text { with grounded conductive } \\
\text { drums }\end{array}$} \\
\hline & combustible powder & & & \\
\hline $\begin{array}{l}\text { non-combustible } \\
\text { powder }\end{array}$ & \multirow{2}{*}{$\begin{array}{l}\text { flammable gas } \\
\text { or vapor } \\
\text { or } \\
\text { hybrid mixture }\end{array}$} & \multirow[t]{2}{*}{ yes } & \multirow{2}{*}{$\begin{array}{l}\text { - filling and emptying } \\
\text { by gravity } \\
\text { - volume } \leq 50 \text { I } \\
\text { - grounding required }\end{array}$} & \multirow[t]{2}{*}{$\begin{array}{l}\text { only use in combination } \\
\text { with grounded conductive } \\
\text { drums }\end{array}$} \\
\hline $\begin{array}{l}\text { combustible } \\
\text { powder }\end{array}$ & & & & \\
\hline $\begin{array}{l}\text { powder with } \\
\text { flammable } \\
\text { solvent }\end{array}$ & any & yes & $\begin{array}{l}\text { - filling and emptying } \\
\text { by gravity } \\
\text { - volume } \leq 50 \text { I } \\
\text { - grounding required }\end{array}$ & $\begin{array}{l}\text { only use in combination } \\
\text { with grounded conductive } \\
\text { drums }\end{array}$ \\
\hline
\end{tabular}




\section{Package}

\subsection{Aluminum bag}

Aluminum bags usually consist of a plastic bag coated with aluminum, which is again coated with an insulating layer of plastic. To facilitate grounding of the aluminum layer bags equipped with a metal stud in contact with the aluminum layer, - It is very difficult to ground the are recommended.

\section{Hazards:}

- If the bag is not grounded, spark discharges may occur. bag (aluminum layer) only by attaching a grounding clamp to its surface. If the plastic layer is not pierced by the grounding clamp, grounding is not ensured.

\begin{tabular}{|c|c|c|c|c|}
\hline Product & $\begin{array}{l}\text { Explosive } \\
\text { atmosphere in } \\
\text { the environment }\end{array}$ & Permitted & $\begin{array}{l}\text { Requirements and } \\
\text { limits during filling } \\
\text { and emptying }\end{array}$ & Remarks \\
\hline $\begin{array}{l}\text { non-combustible } \\
\text { powder }\end{array}$ & none & yes & none & $\begin{array}{l}\text { consider hazards } \\
\text { of electric shock }\end{array}$ \\
\hline \multirow{2}{*}{$\begin{array}{l}\text { combustible } \\
\text { powder }\end{array}$} & none & \multirow[t]{2}{*}{ yes } & \multirow{2}{*}{$\begin{array}{l}\text { - filling and emptying } \\
\text { by gravity } \\
\text { - volume } \leq 50 \text { । } \\
\text { - grounding required }\end{array}$} & \multirow{2}{*}{$\begin{array}{l}\text { if grounding is not ensured, } \\
\text { only use up to a volume of } \\
-5 \text { I in case of powder } \\
\text { with MIE }>1 \mathrm{~mJ} \\
-20 \text { I in case of powder } \\
\text { with MIE > } 10 \mathrm{~mJ} \\
-50 \text { I in case of powder } \\
\text { with MIE }>30 \mathrm{~mJ}\end{array}$} \\
\hline & combustible powder & & & \\
\hline $\begin{array}{l}\text { non-combustible } \\
\text { powder }\end{array}$ & \multirow{2}{*}{$\begin{array}{l}\text { flammable gas } \\
\text { or vapor } \\
\text { or } \\
\text { hybrid mixture }\end{array}$} & \multirow[t]{2}{*}{ yes } & \multirow{2}{*}{$\begin{array}{l}\text { - filling and emptying } \\
\text { by gravity } \\
\text { - volume } \leq 50 \text { I } \\
\text { - grounding required }\end{array}$} & \multirow[t]{2}{*}{$\begin{array}{l}\text { if grounding is not ensured, } \\
\text { aluminum bags should } \\
\text { not be used }\end{array}$} \\
\hline $\begin{array}{l}\text { combustible } \\
\text { powder }\end{array}$ & & & & \\
\hline $\begin{array}{l}\text { powder with } \\
\text { flammable } \\
\text { solvent }\end{array}$ & any & yes & $\begin{array}{l}\text { - filling and emptying } \\
\quad \text { by gravity } \\
\text { - volume } \leq 50 \text { I } \\
\text { - grounding required }\end{array}$ & $\begin{array}{l}\text { if grounding is not ensured, } \\
\text { aluminum bags should } \\
\text { not be used }\end{array}$ \\
\hline
\end{tabular}




\section{Drums}

\section{Package}

\subsection{Metal drum}

\section{Hazard:}

- If the drum is not grounded, spark discharges may occur.

\begin{tabular}{|c|c|c|c|c|}
\hline Product & $\begin{array}{l}\text { Explosive } \\
\text { atmosphere in } \\
\text { the environment }\end{array}$ & Permitted & $\begin{array}{l}\text { Requirements and } \\
\text { limits during filling } \\
\text { and emptying }\end{array}$ & Remarks \\
\hline $\begin{array}{l}\text { non-combustible } \\
\text { powder }\end{array}$ & none & yes & none & $\begin{array}{l}\text { consider hazards } \\
\text { of electric shock }\end{array}$ \\
\hline \multirow{2}{*}{$\begin{array}{l}\text { combustible } \\
\text { powder }\end{array}$} & none & \multirow[t]{2}{*}{ yes } & \multirow{2}{*}{$\begin{array}{l}\text { - filling and emptying } \\
\text { by gravity } \\
\text { - volume } \leq 200 \text { I } \\
\text { - grounding required }\end{array}$} & \\
\hline & combustible powder & & & \\
\hline $\begin{array}{l}\text { non-combustible } \\
\text { powder }\end{array}$ & \multirow{2}{*}{$\begin{array}{l}\text { flammable gas } \\
\text { or vapor } \\
\text { or } \\
\text { hybrid mixture }\end{array}$} & \multirow[t]{2}{*}{ yes } & \multirow{2}{*}{$\begin{array}{l}\text { - filling and emptying } \\
\text { by gravity } \\
\text { - volume } \leq 200 \text { I } \\
\text { - grounding required }\end{array}$} & \\
\hline $\begin{array}{l}\text { combustible } \\
\text { powder }\end{array}$ & & & & \\
\hline $\begin{array}{l}\text { flammable } \\
\text { liquid }\end{array}$ & any & yes & $\begin{array}{l}\text { - volume } \leq 200 \text { I } \\
\text { - grounding required }\end{array}$ & \\
\hline $\begin{array}{l}\text { powder with } \\
\text { flammable } \\
\text { solvent }\end{array}$ & any & yes & $\begin{array}{l}\text { - filling and emptying } \\
\text { by gravity } \\
\text { - volume } \leq 200 \text { I } \\
\text { - grounding required } \\
\text { - conductivity of wet cake } \\
>10^{-8} \mathrm{~S} / \mathrm{m}\end{array}$ & $\begin{array}{l}\text { if the conductivity of the } \\
\text { wet cake is very low, } \\
\text { inert-gas blanketing during } \\
\text { filling is required }\end{array}$ \\
\hline $\begin{array}{l}\text { flammable } \\
\text { suspension }\end{array}$ & any & yes & $\begin{array}{l}\text { - volume } \leq 200 \text { I } \\
\text { - grounding required } \\
\text { - conductivity of suspension } \\
>10^{-8} \mathrm{~S} / \mathrm{m}\end{array}$ & $\begin{array}{l}\text { if the conductivity of the } \\
\text { suspension is very low, } \\
\text { inert-gas blanketing during } \\
\text { filling is required }\end{array}$ \\
\hline
\end{tabular}




\section{Package}

\subsection{Metal drum with thin $(<2 \mathrm{~mm}$ ) insulating coating or paint (inside and/or outside)}

Hazards:

- If the drum is not grounded, spark discharges may occur.

- Grounding may be difficult because the insulating coating or paint may prevent a reliable electrical contact between the metal of the drum and the grounding clamp.

- Spark discharges from a conduc- tive liquid filled into the drum may occur.

\begin{tabular}{|c|c|c|c|c|}
\hline Product & $\begin{array}{l}\text { Explosive } \\
\text { atmosphere in } \\
\text { the environment }\end{array}$ & Permitted & $\begin{array}{l}\text { Requirements and } \\
\text { limits during filling } \\
\text { and emptying }\end{array}$ & Remarks \\
\hline $\begin{array}{l}\text { non-combustible } \\
\text { powder }\end{array}$ & none & yes & none & $\begin{array}{l}\text { consider hazards } \\
\text { of electric shock }\end{array}$ \\
\hline \multirow{2}{*}{$\begin{array}{l}\text { combustible } \\
\text { powder }\end{array}$} & none & \multirow[t]{2}{*}{ yes } & \multirow{2}{*}{$\begin{array}{l}\text { - filling and emptying } \\
\quad \text { by gravity } \\
\text { - volume } \leq 200 \text { I } \\
\text { - grounding required }\end{array}$} & \multirow{2}{*}{$\begin{array}{l}\text { only use in combination with } \\
\text { grounded conductive drums }\end{array}$} \\
\hline & combustible powder & & & \\
\hline $\begin{array}{l}\text { non-combustible } \\
\text { powder }\end{array}$ & \multirow{2}{*}{$\begin{array}{l}\text { flammable gas } \\
\text { or vapor } \\
\text { or } \\
\text { hybrid mixture }\end{array}$} & \multirow[t]{2}{*}{ yes } & \multirow{2}{*}{$\begin{array}{l}\text { - filling and emptying } \\
\text { by gravity } \\
\text { - volume } \leq 200 \text { I } \\
\text { - grounding required }\end{array}$} & \\
\hline $\begin{array}{l}\text { combustible } \\
\text { powder }\end{array}$ & & & & \\
\hline $\begin{array}{l}\text { flammable } \\
\text { liquid }\end{array}$ & any & yes & $\begin{array}{l}\text { - volume } \leq 200 \text { I } \\
\text { - grounding required } \\
\text { - if conductivity of liquid } \\
>10^{-8} \mathrm{~S} / \mathrm{m} \text {, filling with } \\
\text { conductive and grounded } \\
\text { dip-pipe is required }\end{array}$ & \\
\hline $\begin{array}{l}\text { powder with } \\
\text { flammable } \\
\text { solvent }\end{array}$ & any & yes & $\begin{array}{l}\text { - filling and emptying } \\
\text { by gravity } \\
\text { - volume } \leq 200 \text { I } \\
\text { - grounding required } \\
\text { - conductivity of wet cake } \\
>10^{-8} \mathrm{~S} / \mathrm{m} \\
\text { - put a conductive grounded } \\
\text { rod into the drum prior } \\
\text { to filling }\end{array}$ & $\begin{array}{l}\text { if the conductivity of the } \\
\text { wet cake is very low, } \\
\text { inert-gas blanketing during } \\
\text { filling is required }\end{array}$ \\
\hline $\begin{array}{l}\text { flammable } \\
\text { suspension }\end{array}$ & any & yes & $\begin{array}{l}\text { - volume } \leq 200 \text { I } \\
\text { - grounding required } \\
\text { - conductivity of suspension } \\
>10^{-8} \mathrm{~S} / \mathrm{m} \\
\text { - filling with conductive and } \\
\text { grounded dip-pipe is } \\
\text { required }\end{array}$ & $\begin{array}{l}\text { if the conductivity of the } \\
\text { suspension is very low, } \\
\text { inert-gas blanketing during } \\
\text { filling is required }\end{array}$ \\
\hline
\end{tabular}




\section{Package}

\subsection{Metal drum with plastic liner}

Hazard:

- If the drum is not grounded, spark discharges may occur.

\begin{tabular}{|c|c|c|c|c|}
\hline Product & $\begin{array}{l}\text { Explosive } \\
\text { atmosphere in } \\
\text { the environment }\end{array}$ & Permitted & $\begin{array}{l}\text { Requirements and } \\
\text { limits during filling } \\
\text { and emptying }\end{array}$ & Remarks \\
\hline $\begin{array}{l}\text { non-combustible } \\
\text { powder }\end{array}$ & none & yes & none & $\begin{array}{l}\text { consider hazards } \\
\text { of electric shock }\end{array}$ \\
\hline \multirow{2}{*}{$\begin{array}{l}\text { combustible } \\
\text { powder }\end{array}$} & none & \multirow[t]{2}{*}{ yes } & \multirow{2}{*}{$\begin{array}{l}\text { - filling and emptying } \\
\text { by gravity } \\
\text { - volume } \leq 200 \text { I } \\
\text { - grounding required }\end{array}$} & \\
\hline & combustible powder & & & \\
\hline $\begin{array}{l}\text { non-combustible } \\
\text { powder }\end{array}$ & \multirow{2}{*}{$\begin{array}{l}\text { flammable gas } \\
\text { or vapor } \\
\text { or } \\
\text { hybrid mixture }\end{array}$} & \multirow[t]{2}{*}{ no } & & \\
\hline $\begin{array}{l}\text { combustible } \\
\text { powder }\end{array}$ & & & & \\
\hline $\begin{array}{l}\text { flammable } \\
\text { liquid }\end{array}$ & any & no & & \\
\hline $\begin{array}{l}\text { powder with } \\
\text { flammable } \\
\text { solvent }\end{array}$ & any & no & & \\
\hline $\begin{array}{l}\text { flammable } \\
\text { suspension }\end{array}$ & any & no & & \\
\hline
\end{tabular}




\section{Package}

\subsection{Metal drum with plastic liner with antistatic treatment}

With the following specifications:

- Surface resistance below $10^{9} \Omega$ at $50 \%$ relative humidity ( $(\mathrm{hh})$ and $23^{\circ} \mathrm{C}$ and above $10^{8} \Omega$ at $65 \%$ rh and $23^{\circ} \mathrm{C}$

or

- Surface resistance below $10^{11} \Omega$ at $30 \%$ rh and $23{ }^{\circ} \mathrm{C}$ and above $10^{8} \Omega$ at $65 \%$ rh and $23^{\circ} \mathrm{C}$
Hazards:

- If the drum is not grounded, spark discharges may occur.

- The antistatic treatment of the plastic bag may become ineffective within a short period of time.

- The antistatic agent may be adsorbed by the product.

- In case of very dry conditions the surface resistance of the liner may be higher than the permissible upper limit.

- If the surface resistance of the liner does not lie within the required limits, brush or spark discharges may occur.

- If the liner becomes wet and is not in contact with ground, spark discharges may occur.

\begin{tabular}{|c|c|c|c|c|}
\hline Product & $\begin{array}{l}\text { Explosive } \\
\text { atmosphere in } \\
\text { the environment }\end{array}$ & Permitted & $\begin{array}{l}\text { Requirements and } \\
\text { limits during filling } \\
\text { and emptying }\end{array}$ & Remarks \\
\hline $\begin{array}{l}\text { non-combustible } \\
\text { powder }\end{array}$ & none & yes & none & $\begin{array}{l}\text { consider hazards } \\
\text { of electric shock }\end{array}$ \\
\hline \multirow{2}{*}{$\begin{array}{l}\text { combustible } \\
\text { powder }\end{array}$} & none & \multirow[t]{2}{*}{ yes } & \multirow{2}{*}{$\begin{array}{l}\text { - filling and emptying } \\
\text { by gravity } \\
\text { - volume } \leq 200 \text { I } \\
\text { - grounding required }\end{array}$} & \multirow{2}{*}{$\begin{array}{l}\text { only use in combination with } \\
\text { grounded conductive drums }\end{array}$} \\
\hline & combustible powder & & & \\
\hline $\begin{array}{l}\text { non-combustible } \\
\text { powder }\end{array}$ & \multirow{2}{*}{$\begin{array}{l}\text { flammable gas } \\
\text { or vapor } \\
\text {-or } \\
\text { hybrid mixture }\end{array}$} & \multirow[t]{2}{*}{ yes } & \multirow{2}{*}{$\begin{array}{l}\text { - filling and emptying } \\
\text { by gravity } \\
\text { - volume } \leq 200 \text { I } \\
\text { - grounding required }\end{array}$} & \\
\hline $\begin{array}{l}\text { combustible } \\
\text { powder }\end{array}$ & & & & \\
\hline $\begin{array}{l}\text { powder with } \\
\text { flammable } \\
\text { solvent }\end{array}$ & any & yes & $\begin{array}{l}\text { - filling and emptying } \\
\text { by gravity } \\
\text { - volume } \leq 200 \text { I } \\
\text { - grounding required } \\
\text { - conductivity of wet cake } \\
>10^{-8} \mathrm{~S} / \mathrm{m} \\
\text { - put a conductive grounded } \\
\text { rod into the drum prior } \\
\text { to filling }\end{array}$ & $\begin{array}{l}\text { if the conductivity of the } \\
\text { wet cake is very low, } \\
\text { inert-gas blanketing during } \\
\text { filling is required }\end{array}$ \\
\hline
\end{tabular}


Package

\subsection{Metal drum with plastic liner made conductive by the addition of carbon black}

With the following specifications:

- Volume resistivity below $10^{4} \Omega$
Hazards:

- If the drum is not grounded, spark discharges may occur.
- If the conductive liner is taken out of the drum, grounding of the bag may no longer be ensured.

\begin{tabular}{|c|c|c|c|c|}
\hline Product & $\begin{array}{l}\text { Explosive } \\
\text { atmosphere in } \\
\text { the environment }\end{array}$ & Permitted & $\begin{array}{l}\text { Requirements and } \\
\text { limits during filling } \\
\text { and emptying }\end{array}$ & Remarks \\
\hline $\begin{array}{l}\text { non-combustible } \\
\text { powder }\end{array}$ & none & yes & none & $\begin{array}{l}\text { consider hazards } \\
\text { of electric shock }\end{array}$ \\
\hline \multirow{2}{*}{$\begin{array}{l}\text { combustible } \\
\text { powder }\end{array}$} & none & \multirow[t]{2}{*}{ yes } & \multirow{2}{*}{$\begin{array}{l}\text { - filling and emptying } \\
\text { by gravity } \\
\text { - volume } \leq 200 \text { I } \\
\text { - grounding required }\end{array}$} & \multirow{2}{*}{$\begin{array}{l}\text { ensure grounding of the bag } \\
\text { when taking it out of the } \\
\text { drum }\end{array}$} \\
\hline & combustible powder & & & \\
\hline $\begin{array}{l}\text { non-combustible } \\
\text { powder }\end{array}$ & \multirow{2}{*}{$\begin{array}{l}\text { flammable gas } \\
\text { or vapor } \\
\text { or } \\
\text { hybrid mixture }\end{array}$} & \multirow[t]{2}{*}{ yes } & \multirow{2}{*}{$\begin{array}{l}\text { - filling and emptying } \\
\text { by gravity } \\
\text { - volume } \leq 200 \text { I } \\
\text { - grounding required }\end{array}$} & \multirow[t]{2}{*}{$\begin{array}{l}\text { ensure grounding of the bag } \\
\text { when taking it out of the } \\
\text { drum }\end{array}$} \\
\hline $\begin{array}{l}\text { combustible } \\
\text { powder }\end{array}$ & & & & \\
\hline $\begin{array}{l}\text { powder with } \\
\text { flammable } \\
\text { solvent }\end{array}$ & any & yes & $\begin{array}{l}\text { - filling and emptying } \\
\text { by gravity } \\
\text { - volume } \leq 200 \text { I } \\
\text { - grounding required } \\
\text { - conductivity of wet cake } \\
>10^{-8} \mathrm{~S} / \mathrm{m}\end{array}$ & $\begin{array}{l}\text { ensure grounding of the bag } \\
\text { when taking it out of the } \\
\text { drum } \\
\text { if the conductivity of the } \\
\text { wet cake is very low, } \\
\text { inert-gas blanketing during } \\
\text { filling is required }\end{array}$ \\
\hline
\end{tabular}




\section{Package}

\subsection{Metal drum with internal plastic container and small filling/emptying openings}

With the following specifications: Hazards:

- bung holes with diameter - If the drum is not grounded, spark $<50 \mathrm{~mm}$ )

discharges may occur.
- Spark discharges from a conductive liquid filled into the drum may occur.

- Brush discharges from internal plastic container may occur.

\begin{tabular}{|c|c|c|c|c|}
\hline Product & $\begin{array}{l}\text { Explosive } \\
\text { atmosphere in } \\
\text { the environment }\end{array}$ & Permitted & $\begin{array}{l}\text { Requirements and } \\
\text { limits during filling } \\
\text { and emptying }\end{array}$ & Remarks \\
\hline $\begin{array}{l}\text { flammable } \\
\text { liquid }\end{array}$ & any & yes & $\begin{array}{l}\text { - volume } \leq 200 \text { I } \\
\text { - grounding required } \\
\text { - if conductivity of liquid } \\
>10^{-8} \mathrm{~S} / \mathrm{m} \text {, filling with } \\
\text { conductive and grounded } \\
\text { dip-pipe required }\end{array}$ & \\
\hline $\begin{array}{l}\text { flammable } \\
\text { suspension }\end{array}$ & any & yes & $\begin{array}{l}\text { - volume } \leq 200 \text { I } \\
\text { - grounding required } \\
\text { - conductivity of suspension } \\
>10^{-8} \mathrm{~S} / \mathrm{m} \\
\text { - filling with conductive and } \\
\text { grounded dip-pipe required }\end{array}$ & $\begin{array}{l}\text { if the conductivity of the } \\
\text { suspension is very low, } \\
\text { inert-gas blanketing during } \\
\text { filling is required }\end{array}$ \\
\hline
\end{tabular}




\section{Package}

\subsection{Cardboard drum with or without a thin ( $<2 \mathrm{~mm}$ ) insulating coating on one side}

Hazards:

- In a very dry atmosphere and/or in case of high separation speed (> $1 \mathrm{~m} / \mathrm{s}$ ) brush discharges may occur.
- If the cardboard drum becomes wet and is not in contact with ground, spark discharges may occur.
- Spark discharges from any metal reinforcements (metal rings) may occur.

\begin{tabular}{|c|c|c|c|c|}
\hline Product & $\begin{array}{l}\text { Explosive } \\
\text { atmosphere in } \\
\text { the environment }\end{array}$ & Permitted & $\begin{array}{l}\text { Requirements and } \\
\text { limits during filling } \\
\text { and emptying }\end{array}$ & Remarks \\
\hline $\begin{array}{l}\text { non-combustible } \\
\text { powder }\end{array}$ & none & yes & none & $\begin{array}{l}\text { consider hazards } \\
\text { of electric shock }\end{array}$ \\
\hline \multirow{2}{*}{$\begin{array}{l}\text { combustible } \\
\text { powder }\end{array}$} & none & \multirow[t]{2}{*}{ yes } & \multirow{2}{*}{$\begin{array}{l}\text { - filling and emptying } \\
\text { by gravity } \\
\text { - volume } \leq 200 \text { I } \\
\text { - metal reinforcements } \\
\text { must be grounded } \\
\text { in case of dusts with low } \\
\text { minimum ignition energy } \\
\text { (<3 mJ) }\end{array}$} & \\
\hline & combustible powder & & & \\
\hline $\begin{array}{l}\text { non-combustible } \\
\text { powder }\end{array}$ & \multirow{2}{*}{$\begin{array}{l}\text { flammable gas } \\
\text { or vapor } \\
\text { or } \\
\text { hybrid mixture }\end{array}$} & \multirow[t]{2}{*}{ yes } & \multirow{2}{*}{$\begin{array}{l}\text { - filling and emptying } \\
\text { by gravity } \\
\text { - volume } \leq 200 \text { I } \\
\text { - contact to ground via the } \\
\text { operator or conductive } \\
\text { surface of the grounded } \\
\text { equipment } \\
\text { - metal reinforcements } \\
\text { must be grounded }\end{array}$} & \\
\hline $\begin{array}{l}\text { combustible } \\
\text { powder }\end{array}$ & & & & \\
\hline $\begin{array}{l}\text { powder with } \\
\text { flammable } \\
\text { solvent }\end{array}$ & any & no & & \\
\hline
\end{tabular}




\section{Package}

\subsection{Cardboard drum with plastic liner}

Hazards:

- Brush discharges may occur.

- If the cardboard drum becomes wet and is not in contact with ground, spark discharges may occur.
- Spark discharges from any metal reinforcements (metal rings) may occur.

\begin{tabular}{|c|c|c|c|c|}
\hline Product & $\begin{array}{l}\text { Explosive } \\
\text { atmosphere in } \\
\text { the environment }\end{array}$ & Permitted & $\begin{array}{l}\text { Requirements and } \\
\text { limits during filling } \\
\text { and emptying }\end{array}$ & Remarks \\
\hline $\begin{array}{l}\text { non-combustible } \\
\text { powder }\end{array}$ & none & yes & none & $\begin{array}{l}\text { consider hazards } \\
\text { of electric shock }\end{array}$ \\
\hline \multirow{2}{*}{$\begin{array}{l}\text { combustible } \\
\text { powder }\end{array}$} & none & \multirow[t]{2}{*}{ yes } & \multirow{2}{*}{$\begin{array}{l}\text { - filling and emptying } \\
\text { by gravity } \\
\text { - volume } \leq 200 \text { I } \\
\text { - metal reinforcements } \\
\text { must be grounded } \\
\text { in case of dusts with low } \\
\text { minimum ignition energy } \\
\text { (<3 mJ) }\end{array}$} & \\
\hline & combustible powder & & & \\
\hline $\begin{array}{l}\text { non-combustible } \\
\text { powder }\end{array}$ & \multirow{2}{*}{$\begin{array}{l}\text { flammable gas } \\
\text { or vapor } \\
\text { or } \\
\text { hybrid mixture }\end{array}$} & \multirow[t]{2}{*}{ no } & & \\
\hline $\begin{array}{l}\text { combustible } \\
\text { powder }\end{array}$ & & & & \\
\hline $\begin{array}{l}\text { powder with } \\
\text { flammable } \\
\text { solvent }\end{array}$ & any & no & & \\
\hline
\end{tabular}




\section{Package}

\subsection{Cardboard drum with plastic liner with antistatic treatment}

With the following specifications:

- Surface resistance below $10^{9} \Omega$ at $50 \%$ relative humidity (rh) and $23^{\circ} \mathrm{C}$ and above $10^{8} \Omega$ at $65 \%$ rh and $23^{\circ} \mathrm{C}$

or

- Surface resistance below $10^{11} \Omega$ at $30 \%$ rh and $23{ }^{\circ} \mathrm{C}$ and above $10^{8} \Omega$ at $65 \%$ rh and $23^{\circ} \mathrm{C}$
Hazards:

- In a very dry atmosphere and /or in case of high separation speed (> $1 \mathrm{~m} / \mathrm{s}$ ) brush discharges may occur.

- If the cardboard drum becomes wet and is not in contact with ground, spark discharges may occur.

- Spark discharges from any metal reinforcements (metal rings) may occur.

- The antistatic treatment of the plastic bag may become ineffective within a short period of time.
- The antistatic agent may be adsorbed by the product.

- In case of very dry conditions the surface resistance of the liner may be higher than the permissible upper limit.

- If the surface resistance of the liner does not lie within the required limits, brush or spark discharges may occur.

- If the liner becomes wet and is not in contact with ground, spark discharges may occur.

\begin{tabular}{|c|c|c|c|c|}
\hline Product & $\begin{array}{l}\text { Explosive } \\
\text { atmosphere in } \\
\text { the environment }\end{array}$ & Permitted & $\begin{array}{l}\text { Requirements and } \\
\text { limits during filling } \\
\text { and emptying }\end{array}$ & Remarks \\
\hline $\begin{array}{l}\text { non-combustible } \\
\text { powder }\end{array}$ & none & yes & none & $\begin{array}{l}\text { consider hazards } \\
\text { of electric shock }\end{array}$ \\
\hline \multirow{2}{*}{$\begin{array}{l}\text { combustible } \\
\text { powder }\end{array}$} & none & \multirow[t]{2}{*}{ yes } & \multirow{2}{*}{$\begin{array}{l}\text { - filling and emptying } \\
\text { by gravity } \\
\text { - volume } \leq 200 \text { । } \\
\text { - metal reinforcements } \\
\text { must be grounded } \\
\text { in case of dusts with low } \\
\text { minimum ignition energy } \\
(<3 \mathrm{~mJ})\end{array}$} & \\
\hline & combustible powder & & & \\
\hline $\begin{array}{l}\text { non-combustible } \\
\text { powder }\end{array}$ & \multirow{2}{*}{$\begin{array}{l}\text { flammable gas } \\
\text { or vapor } \\
\text { or } \\
\text { hybrid mixture }\end{array}$} & \multirow[t]{2}{*}{ yes } & \multirow{2}{*}{$\begin{array}{l}\text { - filling and emptying by } \\
\text { gravity } \\
\text { - volume } \leq 200 \text { I } \\
\text { - contact to ground via the } \\
\text { operator or conductive } \\
\text { surface of the grounded } \\
\text { equipment } \\
\text { - metal reinforcements } \\
\text { must be grounded }\end{array}$} & \\
\hline $\begin{array}{l}\text { combustible } \\
\text { powder }\end{array}$ & & & & \\
\hline $\begin{array}{l}\text { powder with } \\
\text { flammable } \\
\text { solvent }\end{array}$ & any & no & & \\
\hline
\end{tabular}




\section{Package}

\subsection{Cardboard drum with conductive liner}

With the following specifications:

- plastic bag made conductive by the addition of carbon black
Should not be used for flammable liquids or combustible powders

\section{Package}

\subsection{Fiber drum or plastic drum}

Hazards:

- Brush discharges may occur.

- If the drum becomes wet and is not in contact with ground, spark discharges may occur.

\begin{tabular}{|c|c|c|c|c|}
\hline Product & $\begin{array}{l}\text { Explosive } \\
\text { atmosphere in } \\
\text { the environment }\end{array}$ & Permitted & $\begin{array}{l}\text { Requirements and } \\
\text { limits during filling } \\
\text { and emptying }\end{array}$ & Remarks \\
\hline $\begin{array}{l}\text { non-combustible } \\
\text { powder }\end{array}$ & none & yes & none & $\begin{array}{l}\text { consider hazards } \\
\text { of electric shock }\end{array}$ \\
\hline \multirow{2}{*}{$\begin{array}{l}\text { combustible } \\
\text { powder }\end{array}$} & none & \multirow[t]{2}{*}{ yes } & \multirow{2}{*}{$\begin{array}{l}\text { - filling and emptying } \\
\text { by gravity } \\
\text { - volume } \leq 200 \text { I }\end{array}$} & \\
\hline & combustible powder & & & \\
\hline $\begin{array}{l}\text { non-combustible } \\
\text { powder }\end{array}$ & \multirow{2}{*}{$\begin{array}{l}\text { flammable gas } \\
\text { or vapor } \\
\text { or } \\
\text { hybrid mixture }\end{array}$} & \multirow[t]{2}{*}{ yes } & \multirow[t]{2}{*}{ - volume $\leq 5$} & \\
\hline $\begin{array}{l}\text { combustible } \\
\text { powder }\end{array}$ & & & & \\
\hline $\begin{array}{l}\text { flammable } \\
\text { liquid }\end{array}$ & any & yes & - volume $\leq 51$ & \\
\hline $\begin{array}{l}\text { powder with } \\
\text { flammable } \\
\text { solvent }\end{array}$ & any & yes & - volume $\leq 51$ & \\
\hline $\begin{array}{l}\text { flammable } \\
\text { suspension }\end{array}$ & any & yes & - volume $\leq 51$ & \\
\hline
\end{tabular}




\section{Package}

\subsection{Fiber drum or plastic drum with plastic liner}

With the following specifications:

- normal or antistatic
Hazards:

- Brush discharges may occur.

- If the drum becomes wet and is not in contact with ground, spark discharges may occur.

\begin{tabular}{|c|c|c|c|c|}
\hline Product & $\begin{array}{l}\text { Explosive } \\
\text { atmosphere in } \\
\text { the environment }\end{array}$ & Permitted & $\begin{array}{l}\text { Requirements and } \\
\text { limits during filling } \\
\text { and emptying }\end{array}$ & Remarks \\
\hline $\begin{array}{l}\text { non-combustible } \\
\text { powder }\end{array}$ & none & yes & none & $\begin{array}{l}\text { consider hazards } \\
\text { of electric shock }\end{array}$ \\
\hline \multirow{2}{*}{$\begin{array}{l}\text { combustible } \\
\text { powder }\end{array}$} & none & \multirow[t]{2}{*}{ yes } & \multirow{2}{*}{$\begin{array}{l}\text { - filling and emptying } \\
\text { by gravity } \\
\text { - volume } \leq 200 \text { I }\end{array}$} & \\
\hline & combustible powder & & & \\
\hline $\begin{array}{l}\text { non-combustible } \\
\text { powder }\end{array}$ & \multirow{2}{*}{$\begin{array}{l}\text { flammable gas } \\
\text { or vapor } \\
\text { or } \\
\text { hybrid mixture }\end{array}$} & \multirow[t]{2}{*}{ no } & & \\
\hline $\begin{array}{l}\text { combustible } \\
\text { powder }\end{array}$ & & & & \\
\hline $\begin{array}{l}\text { flammable } \\
\text { liquid }\end{array}$ & any & no & & \\
\hline $\begin{array}{l}\text { powder with } \\
\text { flammable } \\
\text { solvent }\end{array}$ & any & no & & \\
\hline $\begin{array}{l}\text { flammable } \\
\text { suspension }\end{array}$ & any & no & & \\
\hline
\end{tabular}

\section{Package}

\subsection{Fiber drum or plastic drum with conductive liner}

With the following specifications:

- plastic bag made conductive by the addition of carbon black
Should not be used for flammable liquids or combustible powders 


\section{Containers}

\section{Package}

\subsection{Metal container}

Hazards:

- If the container is not grounded, spark discharges may occur.

- Metal containers (e.g. manufactured by Thyssen or Stöckli) normally consist of two main parts: The metal stand and the actual metal container. In the case of Thyssen-type containers the actual metal container does not necessarily make metal-to-metal con- tact with the metallic stand, since a supporting layer, or piece, of insulating rubber is put between the container and the stand at all locations where the container is in contact with and fixed to the stand. Due to this rubber layer or piece of rubber the container is electrically insulated from the stand.
- Depending on the nature of the product, the way of filling and emptying, and the volume of the container, discharges (brush or cone discharges) from the product within the container may occur.

\begin{tabular}{|c|c|c|c|c|}
\hline Product & $\begin{array}{l}\text { Explosive } \\
\text { atmosphere in } \\
\text { the environment }\end{array}$ & Permitted & $\begin{array}{l}\text { Requirements and } \\
\text { limits during filling } \\
\text { and emptying }\end{array}$ & Remarks \\
\hline $\begin{array}{l}\text { non-combustible } \\
\text { powder }\end{array}$ & none & yes & none & $\begin{array}{l}\text { consider hazards } \\
\text { of electric shock }\end{array}$ \\
\hline \multirow{2}{*}{$\begin{array}{l}\text { combustible } \\
\text { powder }\end{array}$} & none & \multirow[t]{2}{*}{ yes } & \multirow[b]{2}{*}{$\begin{array}{l}\text { - filling and emptying } \\
\text { by gravity } \\
\text { - volume } \leq 2000 \text { I } \\
\text { - ground the container } \\
\text { during filling and emptying } \\
\text { operations by attaching a } \\
\text { grounding clamp directly } \\
\text { to the container } \\
\text { - if the resistivity of the } \\
\text { powder is greater than } \\
10^{10} \Omega \cdot m \text { and the median } \\
\text { of the particle size* } \\
\text { is greater than } 0.1 \text { mm, } \\
\text { consider ignition hazards } \\
\text { due to cone discharges } \\
\text { or seek expert advice }\end{array}$} & \multirow{2}{*}{$\begin{array}{l}\text { in case of coarse powders* } \\
\text { (median }>0.1 \mathrm{~mm} \text { ) } \\
\text { with high resistivity } \\
\left(>10^{10} \Omega \cdot \mathrm{m}\right) \text { ignition } \\
\text { hazards due to cone } \\
\text { discharges must be } \\
\text { considered }\end{array}$} \\
\hline & combustible powder & & & \\
\hline $\begin{array}{l}\text { non-combustible } \\
\text { powder }\end{array}$ & \multirow{2}{*}{$\begin{array}{l}\text { flammable gas } \\
\text { or vapor } \\
\text { or } \\
\text { hybrid mixture }\end{array}$} & yes & \multirow{2}{*}{$\begin{array}{l}\text { - filling and emptying } \\
\text { by gravity } \\
\text { - volume } \leq 2000 \text { I } \\
\text { - ground the container } \\
\text { during filling and emptying } \\
\text { operations by attaching a } \\
\text { grounding clamp directly } \\
\text { to the container }\end{array}$} & \multirow{2}{*}{$\begin{array}{l}\text { in case of coarse powders* } \\
\text { (median }>0.1 \mathrm{~mm} \text { ) } \\
\text { with high resistivity } \\
\left(>10^{10} \Omega \cdot \mathrm{m} \text { ) ignition }\right. \\
\text { hazards due to cone } \\
\text { discharges must be } \\
\text { considered }\end{array}$} \\
\hline $\begin{array}{l}\text { combustible } \\
\text { powder }\end{array}$ & & Jumlio mins & & \\
\hline
\end{tabular}

* This is due to the fact that with larger particles more static electricity can be accumulated in a powder heap. 


\section{Continued from page 57}

\begin{tabular}{|c|c|c|c|c|}
\hline 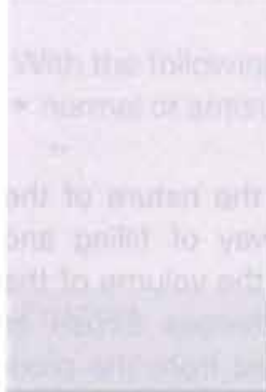 & 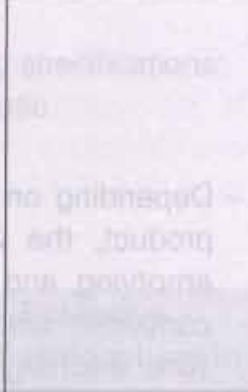 & 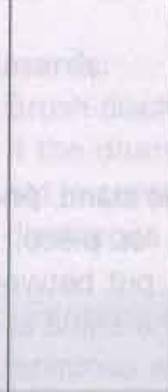 & $\begin{array}{l}\text { - if the resistivity of the } \\
\text { powder is greater than } \\
10^{10} \Omega \cdot \mathrm{m} \text { and the median } \\
\text { of the particle size } \\
\text { is greater than } 0.1 \mathrm{~mm} \text {, } \\
\text { consider ignition hazards } \\
\text { due to cone and brush } \\
\text { discharges or seek expert } \\
\text { advice }\end{array}$ & 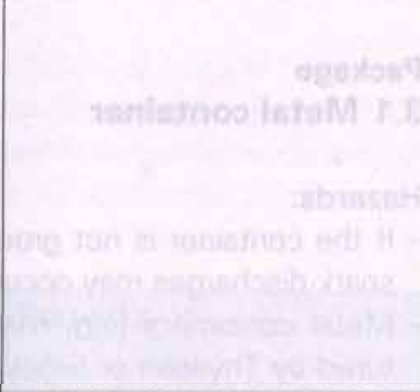 \\
\hline $\begin{array}{l}\text { flammable } \\
\text { liquid }\end{array}$ & any & yes & $\begin{array}{l}\text { - volume } \leq 2000 \text { I } \\
\text { - ground the container } \\
\text { during filling and emptying } \\
\text { operations by attaching a } \\
\text { grounding clamp directly } \\
\text { to the container } \\
\text { - if the volume is larger than } \\
1000 \text { I and the conductivity } \\
\text { of the liquid is less than } \\
1000 \mathrm{pS} / \mathrm{m} \text {, limit the filling } \\
\text { velocity according to } \\
\text { Table } 3, \text { page } 8\end{array}$ & \\
\hline $\begin{array}{l}\text { powder with } \\
\text { flammable } \\
\text { solvent }\end{array}$ & any & yes & $\begin{array}{l}\text { - filling and emptying by } \\
\text { gravity } \\
\text { - volume } \leq 2000 \text { I } \\
\text { - ground the container } \\
\text { during filling and emptying } \\
\text { operations by attaching a } \\
\text { grounding clamp directly } \\
\text { to the container } \\
\text { - conductivity of wet cake } \\
>10^{-8} \Omega \cdot \mathrm{m}\end{array}$ & $\begin{array}{l}\text { if the conductivity of the } \\
\text { wet cake is very low, } \\
\text { inert-gas blanketing during } \\
\text { filling is required }\end{array}$ \\
\hline $\begin{array}{l}\text { flammable } \\
\text { suspension }\end{array}$ & any & yes & $\begin{array}{l}\text { - volume } \leq 2000 \text { I } \\
\text { - ground the container } \\
\text { during filling and emptying } \\
\text { operations by attaching a } \\
\text { grounding clamp directly } \\
\text { to the container } \\
\text { - conductivity of suspension } \\
>10^{-8} \Omega \cdot \mathrm{m}\end{array}$ & $\begin{array}{l}\text { if the conductivity of the } \\
\text { suspension is very low, } \\
\text { inert gas blanketing during } \\
\text { filling is required }\end{array}$ \\
\hline
\end{tabular}

* This is due to the fact that with larger particles more static electricity can be accumulated in a powder heap.

\section{Package}

\subsection{Plastic container with metal shielding in the form of metal plates or a metal grid}

Hazards:

- If the metal plates or metal grid are not grounded, spark discharges may occur.
- Brush discharges from the internal plastic container may occur.

- Spark discharges from a conductive liquid filled into the container may occur.
Should only be used for flammable liquids if safe use for flammable liquids is certified by the manufacturer. 


\section{FIBC (Big Bags)}

\section{Package}

\subsection{Flexible intermediate bulk container (FIBC) Type $A$}

With the following specifications:

- Normal FIBC made from non-conductive polypropylene woven fabric with or without a polyethylene (PE) liner

- The FIBC contains no conductive elements

- Volume not greater than 2000 I

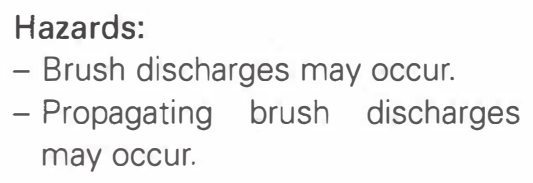

- Brush discharges may occur.

- Propagating brush discharges may occur.

\begin{tabular}{|c|c|c|c|c|}
\hline Product & $\begin{array}{l}\text { Explosive } \\
\text { atmosphere in } \\
\text { the environment }\end{array}$ & Permitted & $\begin{array}{l}\text { Requirements and } \\
\text { limits during filling } \\
\text { and emptying }\end{array}$ & Remarks \\
\hline $\begin{array}{l}\text { non-combustible } \\
\text { powder }\end{array}$ & none & yes & none & $\begin{array}{l}\text { consider hazards } \\
\text { of electric shock }\end{array}$ \\
\hline \multirow{2}{*}{$\begin{array}{l}\text { combustible } \\
\text { powder }\end{array}$} & none & \multirow[t]{2}{*}{ yes } & \multirow{2}{*}{$\begin{array}{l}\text { - minimum ignition energy } \\
\text { of powder MIE }>1 \mathrm{~J}\end{array}$} & \multirow{2}{*}{$\begin{array}{l}\text { consider hazards } \\
\text { of electric shock }\end{array}$} \\
\hline & combustible powder & & & \\
\hline \multirow{2}{*}{$\begin{array}{l}\text { combustible } \\
\text { powder }\end{array}$} & none & \multirow[t]{2}{*}{ no } & \multirow{2}{*}{$\begin{array}{l}\text { - minimum ignition energy } \\
\text { of powder MIE }>1 \mathrm{~J}\end{array}$} & \\
\hline & combustible powder & & & \\
\hline $\begin{array}{l}\text { non-combustible } \\
\text { powder }\end{array}$ & \multirow{2}{*}{$\begin{array}{l}\text { flammable gas } \\
\text { or vapor } \\
\text { or } \\
\text { hybrid mixture }\end{array}$} & \multirow[t]{2}{*}{ no } & & \\
\hline $\begin{array}{l}\text { combustible } \\
\text { powder }\end{array}$ & & & & \\
\hline $\begin{array}{l}\text { powder with } \\
\text { flammable } \\
\text { solvent }\end{array}$ & any & no & & \\
\hline
\end{tabular}




\section{Package}

\subsection{Flexible intermediate bulk container (FIBC) Type B}

With the following specifications:

- Normal FIBC made from non-conductive polypropylene woven fabric

- The breakdown voltage across the FIBC wall, including the wall of the inlet and outlet spout, is less than $4 \mathrm{kV}$

- If the FIBC is used in combination with a liner, the breakdown volt- age across the FIBC wall and the liner, including the wall of the inlet and outlet spout, is less than $4 \mathrm{kV}$

- The FIBC contains no conductive elements

- The volume is not greater than 2000 I

- The FIBC is certified by an accredited testing body
Hazards:

- Brush discharges may occur.

- Propagating brush discharges may occur.

\begin{tabular}{|c|c|c|c|c|}
\hline Product & $\begin{array}{l}\text { Explosive } \\
\text { atmosphere in } \\
\text { the environment }\end{array}$ & Permitted & $\begin{array}{l}\text { Requirements and } \\
\text { limits during filling } \\
\text { and emptying }\end{array}$ & Remarks \\
\hline $\begin{array}{l}\text { non-combustible } \\
\text { powder }\end{array}$ & none & yes & none & $\begin{array}{l}\text { consider hazards } \\
\text { of electric shock }\end{array}$ \\
\hline \multirow{3}{*}{$\begin{array}{l}\text { combustible } \\
\text { powder }\end{array}$} & none & \multirow[t]{3}{*}{ yes } & \multirow{3}{*}{$\begin{array}{l}\text { - filling and emptying by } \\
\text { gravity } \\
\text { - minimum ignition energy } \\
\text { of powder MIE > } 3 \mathrm{~mJ} \\
\text { - if the resistivity of the } \\
\text { powder is greater than } \\
10^{10} \Omega \cdot \mathrm{m} \text { and the median } \\
\text { of the particle size* } \\
\text { is greater than } 0.1 \mathrm{~mm} \text {, } \\
\text { consider ignition hazards } \\
\text { due to cone discharges } \\
\text { or seek expert advice }\end{array}$} & \multirow{3}{*}{$\begin{array}{l}\text { consider hazards } \\
\text { of electric shock } \\
\text { in case of coarse powders* } \\
\text { (median }>0.1 \mathrm{~mm} \text { ) } \\
\text { with high resistivity } \\
\text { (> } 10^{10} \Omega \cdot \mathrm{m} \text { ) ignition } \\
\text { hazards due to cone } \\
\text { discharges must be } \\
\text { considered }\end{array}$} \\
\hline & combustible powder & & & \\
\hline & & & & \\
\hline $\begin{array}{l}\text { non-combustible } \\
\text { powder }\end{array}$ & \multirow{2}{*}{$\begin{array}{l}\text { flammable gas } \\
\text { or vapor } \\
\text { or } \\
\text { hybrid mixture }\end{array}$} & \multirow[t]{2}{*}{ no } & & \\
\hline $\begin{array}{l}\text { combustible } \\
\text { powder }\end{array}$ & & & & \\
\hline $\begin{array}{l}\text { powder with } \\
\text { flammable } \\
\text { solvent }\end{array}$ & any & no & & \\
\hline
\end{tabular}

* This is due to the fact that with larger particles more static electricity can be accumulated in a powder heap. 


\section{Package}

\subsection{Flexible intermediate bulk container (FIBC) Type C}

With the following specifications:

- FIBC Type C shall either be made from a totally conductive fabric or from a non-conductive fabric containing interconnected conductive threads or filaments. These interconnected conductive threads or filaments shall either

- form a reliably interconnected grid enclosing a maximum nonconductive area of $25 \mathrm{~cm}^{2}$ (e.g. $500 \mathrm{~mm}$ mesh size)

or

- be arranged at a distance less than $20 \mathrm{~mm}$ from each other (threads or filaments shall be interconnected at least twice).
- The conductive fabric and the conductive threads or filaments shall have a resistance to the grounding point on the FIBC of less than $10^{8} \Omega$. In addition, all the following requirements shall be met:

- All different conductive parts of the FIBC are bonded to the grounding point via a resistance of less than $10^{8} \Omega$.

- The loops contain conductive threads or filaments bonded to the grounding point via a resistance of less than $10^{8} \Omega$.

- The FIBC has a label indicating the grounding point and indicat- ing the grounding requirement during filling and emptying.

- If the FIBC has an internal insulating coating, the thickness must be less than $2 \mathrm{~mm}$ and the breakdown voltage to the conductive fabric, threads or filaments must not exceed $4 \mathrm{kV}$.

- The volume is not greater than 2000 l.

- The FIBC is certified by an accredited testing body.

\section{Hazard:}

- If the FIBC is not properly grounded, spark discharges may occur.

\begin{tabular}{|c|c|c|c|c|}
\hline Product & $\begin{array}{l}\text { Explosive } \\
\text { atmosphere in } \\
\text { the environment }\end{array}$ & Permitted & $\begin{array}{l}\text { Requirements and } \\
\text { limits during filling } \\
\text { and emptying }\end{array}$ & Remarks \\
\hline $\begin{array}{l}\text { non-combustible } \\
\text { powder }\end{array}$ & none & yes & none & $\begin{array}{l}\text { consider hazards } \\
\text { of electric shock }\end{array}$ \\
\hline \multirow{2}{*}{$\begin{array}{l}\text { combustible } \\
\text { powder }\end{array}$} & none & \multirow[t]{2}{*}{ yes } & - filling and emptying by & \multirow{2}{*}{$\begin{array}{l}\text { in case of coarse powders } \\
\text { (median }>0.1 \mathrm{~mm} \text { ) } \\
\text { with high resistivity } \\
\left(>10^{10} \Omega \cdot \mathrm{m} \text { ) ignition }\right. \\
\text { hazards due to cone } \\
\text { discharges must be } \\
\text { considered }\end{array}$} \\
\hline & combustible powder & & $\begin{array}{l}\text { - ground the FIBC during } \\
\text { filling and emptying } \\
\text { operations by attaching } \\
\text { a grounding clamp to the } \\
\text { grounding point indicated } \\
\text { on the FIBC } \\
\text { - if the resistivity of the } \\
\text { powder is greater than } \\
10^{10} \Omega \cdot \mathrm{m} \text { and the median } \\
\text { of the particle size } \\
\text { is greater than } 0.1 \text { mm, } \\
\text { consider ignition hazards } \\
\text { due to cone discharges } \\
\text { or seek expert advice }\end{array}$ & \\
\hline
\end{tabular}

* This is due to the fact that with larger particles more static electricity can be accumulated in a powder heap.

Continued on page 62 
Continued from page 61

\begin{tabular}{|c|c|c|c|c|}
\hline $\begin{array}{l}\text { non-combustible } \\
\text { powder }\end{array}$ & \multirow[b]{2}{*}{ 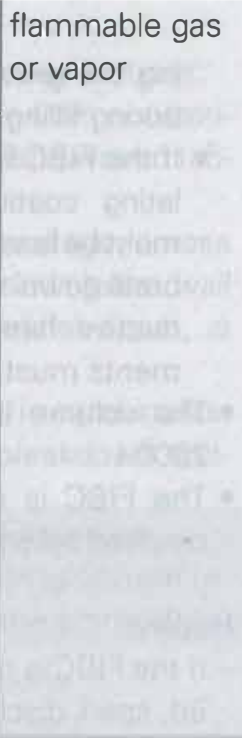 } & \multirow[b]{2}{*}{ 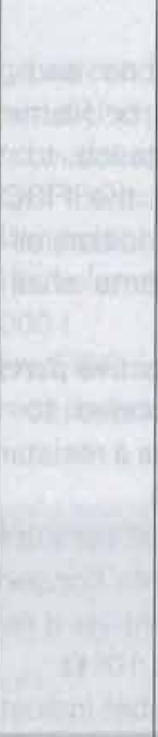 } & \multirow[b]{2}{*}{$\begin{array}{l}\text { - filling and emptying by } \\
\text { gravity } \\
\text { - ground the FIBC during } \\
\text { filling and emptying } \\
\text { operations by attaching } \\
\text { a grounding clamp to the } \\
\text { grounding point indicated } \\
\text { on the FIBC } \\
\text { - if the resistivity of the } \\
\text { powder is greater than } \\
10^{10} \Omega \cdot \mathrm{m} \text { and the median } \\
\text { of the particle size* } \\
\text { is greater than } 0.1 \text { mm, } \\
\text { consider ignition hazards } \\
\text { due to cone and brush } \\
\text { discharges or seek expert } \\
\text { advice }\end{array}$} & \multirow[b]{2}{*}{$\begin{array}{l}\text { in case of coarse powders* } \\
\text { (median }>0.1 \mathrm{~mm}) \\
\text { with high resistivity } \\
\left(>10^{10} \Omega \cdot \mathrm{m}\right) \text { ignition } \\
\text { hazards due to cone } \\
\text { discharges must be } \\
\text { considered }\end{array}$} \\
\hline $\begin{array}{l}\text { combustible } \\
\text { powder }\end{array}$ & & & & \\
\hline $\begin{array}{l}\text { powder with } \\
\text { flammable } \\
\text { solvent }\end{array}$ & any & no & & \\
\hline
\end{tabular}

* This is due to the fact that with larger particles more static electricity can be accumulated in a powder heap. 


\section{Package}

\subsection{Flexible intermediate bulk container (FIBC) Type D}

With the following specifications:

- The key factor in the design of FIBC Type $D$ is the removal of charge by low-energy corona discharges. FIBC Type D are usually made from non-conductive fabric containing conducting threads or filaments which are not interconnected. Grounding of FIBC Type $D$ has only a minor effect on charge dissipation and is not required. Some FIBC are supplied with an additional low-resistivity coating to further reduce the incendivity of the discharges.

- In contrast to FIBC Type B and C, there exist no simple requirements of physical parameters to ensure the safe discharge mechanism. FIBC Type D shall only be used in the presence of a flam- mable atmosphere after they have been qualified as safe - i.e. after it has been demonstrated that no incendive discharges will occur.

- The volume is not greater than 2000 I.

- The FIBC is certified by an accredited testing body.

\section{Hazards:}

- Though grounding of the FIBC Type D itself is not required, grounding of all objects and personnel in the surroundings of the FIBC Type D, which may become charged during filling or emptying due to electrical induction or charge spraying, is required. Thus, any conductive items that may not normally be grounded (e.g. drums on pallets) should either be grounded or removed from the vicinity of the FIBC Type D. In addition, conductive items (e.g. working tools, bolts, and clips) shall not be placed or stored on the FIBC. When the FIBC is supplied with a means to reduce the final residual charge on its surface (e.g. a low-resistivity surface coating) the requirement of grounding conductive items in all but the immediate vicinity of the FIBC may possibly be relaxed.

- In order to prevent incendive spark discharges from the surface of the FIBC it shall not be allowed to become contaminated or coated with conductive material (e.g. water, grease, or oil).

\begin{tabular}{|c|c|c|c|c|}
\hline Product & $\begin{array}{l}\text { Explosive } \\
\text { atmosphere in } \\
\text { the environment }\end{array}$ & Permitted & $\begin{array}{l}\text { Requirements and } \\
\text { limits during filling } \\
\text { and emptying }\end{array}$ & Remarks \\
\hline $\begin{array}{l}\text { non-combustible } \\
\text { powder }\end{array}$ & none & yes & none & $\begin{array}{l}\text { consider hazards } \\
\text { of electric shock }\end{array}$ \\
\hline \multirow{2}{*}{$\begin{array}{l}\text { combustible } \\
\text { powder }\end{array}$} & none & \multirow[t]{2}{*}{ yes } & - filling and emptying by & \multirow{2}{*}{$\begin{array}{l}\text { in case of coarse powders* } \\
\text { (median }>0.1 \mathrm{~mm} \text { ) } \\
\text { with high resistivity } \\
\left(>10^{10} \Omega \cdot \mathrm{m} \text { ) ignition }\right. \\
\text { hazards due to cone } \\
\text { discharges must be } \\
\text { considered }\end{array}$} \\
\hline & combustible powder & & $\begin{array}{l}\text { - grounding of all objects } \\
\text { and personnel in the } \\
\text { surroundings of the FIBC } \\
\text { Type } D, \text { which may } \\
\text { become charged during } \\
\text { filling or emptying due to } \\
\text { electrical induction or } \\
\text { charge spraying, is } \\
\text { required } \\
\text { - if the resistivity of the } \\
\text { powder is greater than } \\
10^{10} \Omega \cdot m \text { and the median } \\
\text { of the particle size } \\
\text { is greater than } 0.1 \text { mm, } \\
\text { consider ignition hazards } \\
\text { due to cone discharges } \\
\text { or seek expert advice }\end{array}$ & \\
\hline
\end{tabular}

* This is due to the fact that with larger particles more static electricity can be accumulated in a powder heap. 
Continued from page 63

\begin{tabular}{|c|c|c|c|c|}
\hline $\begin{array}{l}\text { non-combustible } \\
\text { powder }\end{array}$ & \multirow[t]{2}{*}{$\begin{array}{l}\text { flammable gas } \\
\text { or vapor }\end{array}$} & \multirow[b]{2}{*}{ ingen } & \multirow[b]{2}{*}{$\begin{array}{l}\text { - filling and emptying by } \\
\text { gravity } \\
\text { - grounding of all objects } \\
\text { and personnel in the } \\
\text { surroundings of the FIBC } \\
\text { type } D \text {, which may } \\
\text { become charged during } \\
\text { filling or emptying due to } \\
\text { electrical induction or } \\
\text { charge spraying, is } \\
\text { required } \\
\text { - if the resistivity of the } \\
\text { powder is greater than } \\
10^{10} \Omega \cdot m \text { and the median } \\
\text { of the particle size* } \\
\text { is greater than } 0.1 \text { mm, } \\
\text { consider ignition hazards } \\
\text { due to cone and brush } \\
\text { discharges or seek expert } \\
\text { advice }\end{array}$} & \multirow[b]{2}{*}{$\begin{array}{l}\text { in case of coarse powders* } \\
\text { (median }>0.1 \mathrm{~mm}) \\
\text { with high resistivity } \\
\left(>10^{10} \Omega \cdot \mathrm{m}\right) \text { ignition } \\
\text { hazards due to cone } \\
\text { discharges must be } \\
\text { considered }\end{array}$} \\
\hline $\begin{array}{l}\text { combustible } \\
\text { powder }\end{array}$ & & & & \\
\hline $\begin{array}{l}\text { powder with } \\
\text { flammable } \\
\text { solvent }\end{array}$ & any & no & & \\
\hline
\end{tabular}

* This is due to the fact that with larger particles more static electricity can be accumulated in a powder heap. 
[1] CENELEC (European Committee for Electrotechnical Standardization), Technical Report CLC/TR 50404, "Electrostatics - Code of practice for the avoidance of hazards due to static electricity", CENELEC Central Secretariat, B-1050 Brussels, June 2003.

[2] HVBG (Hauptverband der gewerblichen Berufsgenossenschaften), "Vermeidung von Zündgefahren infolge elektrostatischer Aufladungen", BGR 132, Jedermann-Verlag, D-69021 Heidelberg, 2003.

[3] BSI (British Standards Institution), "Code of practice for control of undesirable static electricity", BS 5958 Part 1 (1991): "General considerations"; Part 2 (1991): "Recommendations for particular industrial situations", BSI, London W1A 2BS, 1991.

[4] NFPA (National Fire Protection Association), "Recommended Practice on Static Electricity", NFPA 77, Quincy, MA 022699101, 2000.

[5] Shell Safety Committee, "Static Electricity, Technical and Safety Aspects", Shell Internationale Petroleum Mij. B. V., The Hague, June 1988.

[6] EN (European standard), "Explosive Atmospheres - Explosion Prevention and Protection - Part 1: Basic concepts and methodology", EN 1127-1: $2004^{16}$.

[7] HVBG (Hauptverband der gewerblichen Berufsgenossenschaften), "ExplosionsschutzRegeln (EX-RL) Band I: EXplosionsschutz-Regel, Band II: Beispielsammlung zu den Explosionsschutz-Regeln (EX-RL), BGR 104, Jedermann-Verlag, D-69021 Heidelberg, 2002.
[8] Nabert K., Schön G., Redeker T., "Sicherheitstechnische Kennzahlen brennbarer Gase und Dämpfe», 3. Auflage, Deutscher Eichverlag, D-38102 Braunschweig, 2004.

[9] Suva (Swiss National Accident Insurance Fund), "Sicherheitstechnische Kennzahlen von Flüssigkeiten und Gasen", Suva-Form. 1469.d, Suva, Bereich Chemie, CH-6002 Luzern, 1999.

[10] Brandes E., Möller W., "Sicherheitstechnische Kenngrössen, Band 1: Brennbare Flüssigkeiten und Gase», Verlag für neue Wissenschaft, D-27511 Bremerhaven, 2003.

[11] Molnárné M., Schendler Th., Schröder V., "Sicherheitstechnische Kenngrössen, Band 2: Explosionsbereiche von Gasgemischen", Verlag für neue Wissenschaft, D-27511 Bremerhaven, 2003.

[12] ISSA (International Social Security Association), "Static Electricity - Ignition hazards and protection measures", Prevention Series No. 2017 (E), D-69115 Heidelberg, 1996.

[13] ESCIS (Expert Commission for Safety in the Swiss Chemical Industry), "Static Electricity Ignition hazards and protection measures. An Interactive Tutorial", CD-ROM V. 1.2e, Suva, Bereich Chemie, $\mathrm{CH}-6002$ Luzern, 2002.

[14] Glor M., "Electrostatic Hazards in Powder Handling", Research Studies Press, Letchworth, Herdfordshire, England, 1988.

[15] Glor M., "Hazards due to electrostatic charging of powders", Journal of Electrostatics 16 (1985) 175-191.
[16] Glor M., "Discharges and hazards associated with the handling of powders", Inst. Phys. Conf. Ser. No. 85: Section 3 (1987) 207-216.

[17] Berthold W. (Herausgeber), "Bestimmung der Mindestzündenergie von Staub/LuftGemischen", Fortschritt-Berichte VDI, Reihe 3: Verfahrenstechnik Nr. 134, VDIVerlag, D-40239 Düsseldorf, 1987.

[18] Glor M., Maurer B., "Zündfähigkeit von Schüttkegelentladungen", Fortschritt-Berichte VDI, Reihe 3: Verfahrenstechnik Nr. 181, VDI-Verlag, D-40239 Düsseldorf, 1989.

[19] Glor M., Maurer B., "Bestimmung der Zündfähigkeit von Schüttkegelentladungen", Fortschritt-Berichte VDI, Reihe 3: Verfahrenstechnik Nr. 389, VDI-Verlag, D-40239 Düsseldorf, 1995.

[20] Glor M., "Overview of the occurrence and incendivity of cone discharges with case studies from industrial practice", Journal of Loss Prevention in the Process Industries 14 (2001) 123-128.

[21] Glor M., "Ignition hazard due to static electricity in particulate processes", Powder Technology 135-136 (2003) 223233.

[22-31] Proceedings of International Conferences on Electrostatics:

[22] Wien 1970: Verlag AUXILIA SA.

[23] Brüssel 1970.

[24] Frankfurt 1973: DechemaMonographien, Band 72.

[25] Grenoble 1977: Proc. 3rd Int. Congr. Static Electricity EFCE.

[26] Den Haag 1981: Journal of Electrostatics Volume 10.

${ }^{16}$ Revision of EN 1127-1: 1997. 
[27] Uppsala 1985: Journal of Electrostatics Volume 16 \& 17.

[28] Budapest 1989: Journal of Electrostatics Volume 23.

[29] Lahnstein 1993: Journal of Electrostatics Volume 30.

[30] Poitiers 1997: Journal of Electrostatics Volume 40 \& 41

[31] Zakopane 2001: Journal of Electrostatics Volume 51 \& 52.

[32-38] Proceedings of Internation-

al Conferences of the Institute of Physics.

[32] Oxford "Electrostatics 1979": The Institute of Physics Conference Series no. 48.

[33] Oxford "Electrostatics 1983": The Institute of Physics Conference Series no. 66.

[34] Oxford "Electrostatics 1987": The Institute of Physics Conference Series no. 85.

[35] Oxford "Electrostatics 1991": The Institute of Physics Conference Series no. 118.

[36] York "Electrostatics 1995": The Institute of Physics Conference Series no. 143.

[37] Cambridge "Electrostatics 1999": The Institute of Physics Conference Series no. 163.

[38] Edinburgh "Electrostatics 2003": to be published in the Institute of Physics Conference Series.

[39] EN 292-1: 2000, "Safety of machinery - Basic concepts, general principles for design Part 1: Basic terminology, methodology. "*

[40] EN 1081: 1998, "Resilient floor coverings - Determination of the electrical resistance."

\footnotetext{
* For further EN standards see also
} www. cenorm.be/catweb/cwen.htm
[41] EN 1149-1: 1996, "Protective clothing - Electrostatic properties - Part 1: Surface resistivity (Test methods and requirements)."

[42] EN 1149-2: 1997, "Protective clothing - Electrostatic properties - Part 2: Test method for measurement of the electrical resistance through a material (vertical resistance)."

[43] prEN 1149-3: 2001, "Protective clothing - Electrostatic properties - Part 3: Test method for measurement of charge decay."

[44] EN 12115: 1999, "Rubber and thermoplastic hoses and hose assemblies for liquid or gaseous chemicals - Specification."

[45] EN 13463-1: 2001, "Non-electrical equipment for potentially explosive atmospheres - Part 1: Basic method and requirements."

[46] EN 13821: 2003, "Potentially explosive atmospheres - Explosion prevention and protection - Determination of minimum ignition energy of dust/ air mixtures."

[47] prEN 14125: 2003, "Pipework for underground installation at petrol stations."

[48] EN 50014: 2000, "Electrical apparatus for potentially explosive atmospheres - General requirements."

[49] EN 50015: 1998, "Electrical apparatus for potentially explosive atmospheres - Oil immersion ' $O$ '."

[50] EN 50016: 2002, "Electrical apparatus for potentially explosive atmospheres - Pressurized apparatus ' $p$ '."

[51] EN 50017: 1998, "Electrical apparatus for potentially explosive atmospheres - Powder filling ' $q$ '."
[52] EN 50018: 2000, +A1: 2002, "Electrical apparatus for potentially explosive atmospheres - Flameproof enclosures 'd'."

[53] EN 50019: 2000, "Electrical apparatus for potentially explosive atmospheres - Increased safety ' $e$ '."

[54] EN 50020: 2002, "Electrical apparatus for potentially explosive atmospheres - Intrinsic safety ' $i$ '."

[55] EN 50050: 2001, "Electrical apparatus for potentially explosive atmospheres - Electrostatic hand-held spraying equipment."

[56] EN 50059: 1990, "Specification for electrostatic hand-held spraying equipment for nonflammable material for painting and finishing."

[57] EN 50176: 1996, "Automatic electrostatic spraying installations for flammable liquid spraying material."

[58] EN 1360: 2003, "Rubber and hose assemblies for measured fuel dispensing - Specification."

[59] EN 50177: 1996, "Automatic electrostatic spraying installations for flammable coating powder."

[60] EN 50223: 2001, "Automatic electrostatic application equipment for flammable flock material. "

[61] prEN 50281-3: 2002, "Equipment for use in the presence of combustible dust - Part 3: Classification of areas where combustible dust are or may be present."

[62] EN 60243-1: 1999, "Electrical strength of insulating materials - Test methods - Part 1: Test at power frequences. " 
[63] EN 60079-10: 2003, "Electrical apparatus for explosive gas atmospheres - Part 10: Classification of hazardous areas. "

[64] EN 61241-2-2: 1996, "Electrical apparatus for use in the presence of combustible dust - Part 2: Test methods - Section 2: Method for determining the electrical resistivity of dust in layers."

[65] EN 61340-2-3: 2000, Electrostatics - Part 2-3: "Methods of test for determining the resistance and resistivity of solid planar materials used to avoid electrostatic charge accumulation."

[66] prEN 61340-4-1: 2003, Electrostatics - Part 4-1: Standard test methods for specific applications, "Electrical resistance of floor coverings and installed floors."

[67] EN 61340-4-3: 2002, "Electrostatics - Part 4-3: Standard test methods for specific applications; Footwear."

[68] DIN 51412-1: 1979, "Testing of petroleum products; determination of the electrical conductivity, laboratory method. "

[69] DIN 51412-2: 1979, "Testing of petroleum products; determination of the electrical conductivity, field method."

[70] DIN 54345-5: 1985, "Testing of textiles; electrostatic behaviour; determination of electrical resistance of strips of textile fabrics."

[71] IEC 60093: 1993, "Methods of test for insulating materials for electrical purposes; volume resistivity and surface resistivity of solid electrical insulating materials."
[72] IEC 60167: 1993, "Methods of test for insulating materials for electrical purposes; insulation resistance of solid materials. "

[73] IEC 61241-2-3: 1994, "Electrical apparatus for use in the presence of combustible dust - Part 2: Test methods - Section 3: Method for determining minimum ignition energy of dust/air mixtures."

[74] IEC 61340-4-1: 2001, "Electrostatics - Part 4-1: Standard test methods for specific applications; Electrical resistance of floor coverings and installed floors." 
Access port, manipulations

on an open

9-11, 14, 16

15,28

Acetylene

34,35

Aerosols

Agitator

$5,9,11,22$

Agitator vessels,

charging of

$9,10,21,22$

Alcohol

$6,28,29,35$

Antistatic additives

Atmospheric humidity

Bags, filling, emptying

39-45

Ball valve

Basic equations

36,37

Brush discharges

$9,10,13-17$, $19-21,26,32,33$, $35,39-42,51-56$,

$58-60,62,64$

Building, electrostatic

behavior

$21,22,26,35$

Cable rollers

22

Cans

11

Capacitance

$23,25-27,36$

Capacitance, data from

actual practice

Carbon dioxide

Carbon disulfide

Carpeted floors

Centrifuge

Chargeability of dusts

Charged cloud

Charged particles

Charge generation

Charge separation

19-21, 31 $39-41,52,54$

Charging current,

measuring

Charging of dry powders into an empty vessel into a vessel containing flammable solvent

Charging of liquids into cans, containers into charged vessels into drums into tanker vehicles and vehicle fuel tanks

28

12

$6,8,11$,

$15,28,29$

$6,21,28$

$12,16,17$

\section{7}

33

33

5

12,31

$5,9,12-14$,

25,27

14-17

11,12
Charging of powders

containing solvents

Clothing made of synthetic

fibers, charging

Coating, insulating $18-20,22,27$, $47,52,61,63$

Concrete structure, concrete floor electrostatic behavior Conductivity

$6,7,10,11,15$, $17-19,21,22$,

Conductivity, measurement of;

IEC 60093, IEC 60167

Containers, size and

materials of construction

Containers, filling,

$$
\text { emptying }
$$

Conveyor belt

Corona discharges $13,18,32,33$

Coupling

Crystallization process

Curvature, radius of

Data from actual practice

Definitions and symbols

Design and construction,

$$
\text { hints }
$$

Discharge, types of

Discharge resistance,

data from actual practice 28,29

Discharge time

$27,36,37$

Double layer, electric

Drums, filling, emptying

Drum pump

Dry ice (carbon dioxide)

Drying

Dust

$6,7,13,16-20,27$ $28,31,33-35$

Dust explosion hazard

Dust filter

Dust separator

Electric field, measure-

11, 12 Electrons

11 Electrostatic charges,

11 generation

Electrostatic induction
21,28

29,31

27

9,12

57,58

20

$7,10,11$

32-34

27-29

36,37

21-23

$17,32-35$

31,32

9, 46-56

12

9

13

20,35

Enamel

10,23

Enameled flanges, pipes,

vessels, valves,

apparatus

$8,10,12,22,23$

Equalizing conductor

9

Equations, basic

36,37

Equalization of charges

Ether $6-8,28,29$

Explosion limit, explosion range $6,11,19,33,34$

Explosion protection,

primary

$13,19,20$

External paint and plastic

apparatus and pipelines

8, 20-23, 47

FIBCs, filling, emptying 17-19, 59-63

Field strength, lines of force,

field distortion $\quad 19,25,26,28$,

$32,33,36$

Field strength, critical

32

Filters

$7,8,12,16,17$,

$19,20,22,35$

Filters, conductive

$16,19,20$

Filtration of suspensions

12

Flanges

$5,8,11,19$,

Flanges on glass

$22,23,26,35$

and plastic lines

8,20 ,

Flaps, dampers

$22,23,35$

Flash point

8,22

$6,9,11-16$,

$18,34,35$

Floor $\quad 6,9,15,17,21,26,28,35$

Floors, leakage

resistance

$21,26,28$

Fluid bed drying

19

Foils

20

Formula, collection $\quad 36,37$

Funnel

$9,13-16$

19

Glass lines 23

Glass vessels

11

Granulate, charging

19

25, 26

Graphite addition, for improved

31 grounding of bearings

21

5, 31, 32 Grounding, ground

conductors

5, 21-23

5, 31-33

Grounding brushes

20 
Grounding resistance, checks

Grounding wedges

Hazard caused by discharge

Hints for planning

and construction

Hoses

Human body

Humidification of the air

13, 15-17, 19,

Hybrid mixtures

33, 34, Annex C

Hydrocarbons

Hydrogen

$6,8,29$

15,28

Ignition, capability

(of a discharge)

Ignition energy

Ignition point

Ignition probability

Ignition, readiness

Ignition source

Inerting $\quad 10-13,16,17,19,20$

Influence (electrostatic

induction)

Insulation, metal sheaths

Insulator

Internal paint, insulating,

in metal silos

lons

Iron girders of a building

Leakage resistance of apparatus, structural

Leakage resistance of parts of buildings

Leakage resistance of flanges

Leakage resistance of floors

Leakage resistance of footwear

Leakage resistance of transmission belts

Lenard effect

Level control

Lightning-like discharge

Lining, insulating Liquids, chargeability Liquids, conductive 20

34

$21-23$

22

$28,33,34$

5,26

$26-28$

$19,32-34$

$7,22,31$
18, 26 (hazards, containers)

7,8

$$
\text { Liquic }
$$

Long-wave receiver

to detect discharges

Lubricants to improve conductivity

33, 34 Man as a carrier of charges

Measuring rod

6 Metal bolts, grounding

34 Metal parts, isolated

5, 6, 13 Metal pipelines

5, 6 Microfilters

$$
8,17
$$

Minimum ignition energy

of flammable mixtures
$6,7,9,11$, $12,15,35$,
Annex C
8
6

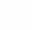

27,29

$5,8,10$

7,9

26

21

21

10

8,22

8

22

22
7

5 Molybdenum sulfide, $27,28,33,34$

6,21
33,34
13
to improve grounding of bearings

22 Nitrogen, purging with

Non-conductors

Nozzle, metal
Nutsch filters

Package (permissibility)
$5,9,11,12,19$
$12,16,22$

10,11,

16,35

$5,31,34$

11
35
34
19

Paint on metal pipes

Paper film

$12,38-64$

$8,20,22$

5,22

Parameters, electrostatic

Permissibility (types of

package)

$12,38-64$

26 Plastic bag

Plastic flanges on glass lines 22

Plastic film

Plastic lining

$13,15-17,48-50$

$53,54,56$

15 Plastic pipe

6 Plastic tube

$5,6,8,20,23,35$

12

Liquids, flammable

Person, walking on carpet

Point discharge

$20,21,33,34$

Point for ionization, activated 20

Porcelain apparatus $\quad 22$

Potentials, data from

actual practice

28,29

Powders

$5,6,12-19,22,23$

Pressure Nutsch filter,

$27,28,33,35$

closed, agitated

Principles for protective

measures

Protective measures, general

PVC

Receiver for long waves

to measure discharges

Relaxation behavior of powders 27

Relaxation time

$27,32,36$

Residual moisture

15

Resistance 28

Resistance, electrical, of hose

Resistivity

$6,7,9,16,18$,

27-29, 36

Resistivity, data from

industrial plants

Resistivity, of liquids

6,29

Rotary valve

Sampling 10

Sampling beaker 10

Schwenkhagen, instrument

to measure field strength

Screen

$13,19,27$

Secondary explosion 13

Sensitivity, of humans 28

Separation processes $5,9,12-14$,

Shoes 6, 21

Shoes, conductive $\quad 9,11,15$, 17,21

Shoe tester 27

Silo 13, 19, 22, 26, 33

Soles of shoes, desirable

resistance 28

Solids as non-conductors $\quad 31$

Solids, containing solvents 12,13

Solvents, see liquids

Solvent-free (definition) 14

Pneumatic transfer $\quad 9,13,20,28$ Solvent vapor $\quad 10,11,13,17$ 
Sparks, puncturing by

Spark discharge

Special funnel

Spray drying

Spraying of liquids

Statometer

Steam ejector

Steel girders of a building

Steel structure,

electrostatic behavior

Stockings

Storage tanks, metal

Sudden discharge

(spark discharge)

Surface resistance

Surface resistance,

of filter fabric

10 Wooden shovels

15,16

9, 13, 17-19,

32,35

11,16

19

$5,9,18$

25,26

$8,22,28$

22

22

27

22

32

$22,27,31,36$

Surface resistance,

dependence on atmospheric

humidity

21,22

Surface resistance, measure-

ment of

Suspension

$6-8,10,12$

Suspension (filtration)

Symbols

36

Tanker vehicles, vehicle tanks 11

Tank, storage (metal) 22

Tantalum plug

10

Teflon

$10,22,28$

Teraohmmeter

26

Time constant

36

Transmissions

Transmission belts

Transport of liquids

22

26,28

7-12

Vacuum, "closed"

(to charge liquids)

10,11

Valve

$7-9,14,20,22,23$

V-belt

Vehicles, charging

and discharging

Velocity, of flow

Ventilation system

$6,7,10,20,35$

Vibratory conveyor

11,16

Voltage

Voltage, measurement

of to measure resistance

25,26

Voltmeter, electrostatic
Wooden structure of a building,

electrostatic behavior

21 


\section{Expert Commission for Safety in the Swiss Chemical Industry (ESCIS)}

\section{Tasks and Aims}

ESCIS promotes safety in the chemical industry. Its members are individuals with responsibilities for safety in companies in the chemical industry, the Swiss National Accident Insurance Fund (SUVA), the Swiss Federal Labor Inspectorate, and other professional organizations, who are in a position to further the interests of safety and in particular, safety training. All members of ESCIS are elected personally based on their qualifications and experience. ESCIS endeavors to recognize current safety problems and fundamental safety aspects of particular importance at an early stage, and to initiate and promote their treatment by specialists or working parties. The aim is to minimize risks by suitable measures, and by continuously extending and improving the methods and instruments used to identify risks. In collaboration with the responsible authorities and institutions, ESCIS strives for meaningful interpretations and practical solutions within the framework of legislation and other official regulations. It is at the service of such bodies for the preparation of guidelines and the establishment of legal bases.
In situations where legal bases or recognized guidelines for industrial safety problems are lacking, ESCIS attempts to derive practicable recommendations based on practical experience and the findings of working parties.

Findings and working party results arising from ESCIS activities are published in appropriate form. These publications are of an advisory nature: decisions regarding their applicability are the sole responsibility of the end user.

ESCIS promotes safety training at educational institutions. It endeavors to integrate safety interests on a broad basis into scientific and technical education, and hence into curricula and examinations. It makes an active contribution to such training through courses, factory visits, technical lectures, and publications.

Individuals and institutions making outstanding contributions to safety in chemical technology may be awarded the ESCIS prize for chemical safety.

The activities of ESCIS are financed primarily by income from the sale of its publications.

January 1998

\section{Members \\ of the Expert Commission for Safety in the Swiss Chemical Industry}

\author{
Mitglieder \\ der Expertenkommission \\ für Sicherheit in der Chemischen \\ Industrie der Schweiz (ESCIS)
}

Dr J. Baechtiger, Swiss Federal Labor Inspectorate, Lausanne

$\operatorname{Dr}$ Ch. Favez, Firmenich SA, La Plaine

Prof. Dr K. Hungerbühler, ETH, Zurich

Dr P. R. Marbet, Novartis Pharma AG, Basel

Dr St. Mischler, Lonza AG, Visp (Commission Officer)

Dr R. J. Ott, Suva, Lucerne (Commission Officer)

Dr A. Roesle, F. Hoffmann-La Roche AG, Basel (Chairman)

Dr H. J. Rüegg, Sicherheitsinstitut, Zurich

A. Schaerli, Basel (Honorary Member)

K. Strässle, Zurich Financial Services, Zurich

W. Wehner, Ciba Spezialitätenchemie AG Schweizerhalle, Pratteln

\section{Commission des Experts pour la Sécurité dans I'Industrie Chimique en Suisse}

Inquiries concerning this publication should be addressed to: Dr R. J. Ott, Bereich Chemie, Abt. Arbeitssicherheit, Suva, Postfach, 6002 Lucerne (e-mail roland.ott@suva.ch) 


\section{Booklets published to date in the ESCIS SAFETY series:}

Nr. 1 Sicherheitstests für Chemikalien, 1998, 4., überarbeitete Auflage

№ 1 Tests de sécurité pour produits chimiques, 1985

Nr. 2 Statische Elektrizität

Regeln für die betriebliche Sicherheit, 1997, 4. Auflage (unveränderter Nachdruck der 3. Auflage)

No. 2 Static Electricity

Rules for Plant Safety, 2005, 2nd, revised edition

Nr. 3 Inertisierung

Methoden und Mittel zum Vermeiden zündfähiger Stoff-Luft-Gemische in chemischen

Produktionsapparaturen und -anlagen, 1992, 2., überarbeitete Auflage

No. 3 Inerting

Methods and Measures for the Avoidance of Ignitable Substance-Air Mixtures

in Chemical Production Equipment and Plants, 1994, translation of 2nd, revised German edition

Nr. 4 Einführung in die Risikoanalyse

Systematik und Methoden, 1996, 3., überarbeitete Auflage

$N^{\circ} 4 \quad$ Introduction à l'analyse des risques

Systématique et méthodes, 1981

No. 4 Introduction to Risk Analysis

Approaches and Methods, 1998, translation of 3rd, revised German edition

$N^{\circ} 4$ Introdução à Análise de risco

Sistemática e Métodos, versão brasileira, 1997

Nr. 5 Mahlen brennbarere Feststoffe

Sicherheitsbeurteilung des Mahlgutes, Schutzmassnahmen an Mahlanlagen,

1993, 3., überarbeitete Auflage

$\mathrm{N}^{\circ} 5$ Broyage des substances combustibles

Evaluation de sécurité des substances à broyer. Mesures de protection des installations de broyage.

Tests de contrôle des substances à broyer, 1987.

No. 5 Milling of Combustible Solids

Safety Evaluation of the Feed Material, Protective Measures with Mills, 1994,

translation of 3rd, revised German edition

№ 5 Moagem de substâncias combustiveis

Avaliação de segurança sobre o material a ser moído, Medidas de proteção aplicadas a instalações de moagem, versão brasileira, 1997

Nr. 6 Trocknen von Feststoffen, 2001, 2., vollständig überarbeitete Auflage

No. 6 Drying of Solids, 2003, translation of 2nd, revised German edition

Nr. 7 Brandschutz an Lüftungs- und Klimaanlagen

in Laborbauten und Betrieben der chemischen Industrie, 1990, 2., unveränderte Auflage 
Nr. 8 Thermische Prozess-Sicherheit

Daten, Beurteilungskriterien, Massnahmen, 1989, 2. Auflage

№ 8 Sécurité thermique des procédés chimiques

Données, critères de jugement, mesures, 1991

No. 8 Thermal Process Safety

Data, Assessment Criteria, Measures, 1993

Nr. 9 Behelf für die Durchführung von Sicherheitsprüfungen (Safety Audits)

Grundsätze, Systematik, Methodik, Stichworte, 1991

Nr. 10 Risikoanalyse im Zusammenhang mit der Störfallverordnung (StFV)

Behelf zur Erstellung von Kurzberichten und Risikoermittlung für Betriebe mit Stoffen,

Erzeugnissen und Sonderabfällen, 1991

Nr. 11 Behelf zur Ermittlung der Erdbebensicherheit von Bauten und Anlagen der chemischen Industrie

Umsetzung der Norm SIA 160, Beurteilungskriterien, Schutzbedarf, 1994

Nr. 12 Schutz gegen Stoffaustritt

als Folge notfallmässiger Druckentlastung, 1996

Nr. 13 Arbeitshygiene

Beurteilung des Gesundheitsrisikos am Arbeitsplatz, 1999

ESCIS TUTORIALS (computer-aided teaching aids) published to date:

Thermal Safety Tutorial, Version 1.0, 1997

Statische Elektrizität Tutorial, Version 1.1d, 2000

Static Electricity Tutorial, Version 1.2e, 2002

Special brochures published to date in the ESCIS SAFETY series:

Wegleitung für den Brandschutz und die Brandbekämpfung in Freilufttankanlagen im Inneren von Fabrikarealen der chemischen Industrie, 1990

Wegleitung: Raumlüftung in Stückgutlagern für Chemikalien, 1991 


\section{ESCIS VIDEOS}

\section{Explosionsschutz, 1998}

Video Part 1 Risikoanalyse und sicherheitstechnische Kenngrössen

Video Part 2 Vorbeugender Explosionsschutz

Video Part 3 Konstruktiver Explosionsschutz

Video Part 4 Risiken und Schutzmassnahmen, Kurzpräsentation der Videos 1-3

\section{Explosion Protection, 1998}

Video Part 1 Risk analysis and safety characteristics

Video Part 2 Preventive explosion protection

Video Part 3 Constructional explosion protection

Video Part 4 Risks and protective measures, brief presentation of videos 1-3

\section{Protección contra Explosiones, 2001}

Video Parte 1 Análisis de riesgos y características de seguridad

Video Parte 2 Protección preventiva contra explosiones

Video Parte 3 Protección constructiva contra explosiones

Video Parte 4 Breve presentación de los videos 1 a 3

\section{Proteção contra Explosões, 1999}

Video Parte 4 Apresentação sumária das vídeos 1-3 


\section{Bulletins published to date by ESCIS}

Nr. 1 Der einfache Fehler, Februar 1994

No 1 La simple faute, février 1994

Nr. 2 Transportsicherheit, Juni 1995

No 2 Sécurité des transports, juin 1995

Nr. 3 Routine - eine Gefahr?, November 1995

No 3 La routine - un danger?, novembre 1996

Nr. 4 Schlauchleitungen/-verbindungen, August 1997

No 4 Conduites flexibles et leurs raccordements, septembre 1997

Nr. 5 Prozessleitsysteme und Ereignisse:

Zur Sicherheit von computergesteuerten Anlagen, August 1998

No 5 Systèmes de conduite de procédé et événements:

De la sécurité des installations conduites par ordinateur, août 1998

No. 5 Process Computers and Incidents:

Reflexions on the safety of computer controlled plant, August, 1998

Nr. 6 Chemikalienlager, Mai 1999

No. 6 Warehouses for Chemicals, May 1999

Nr. 7 Schadenereignisse in Ventilationssystemen, Juni 2000

No. 7 Fires/Losses in Ventilator Systems, June 2000

Nr. 8 Immer wieder die gleichen Ursachen!, Juni 2002

No. 8 The causes are always the same!, June 2002

Copies of the above publications can be obtained from

Dr. R. J. Ott, Bereich Chemie, Abteilung Arbeitssicherheit, Suva, Postfach,

Telephone +414141953 31, Fax +414141952 04, e-mail roland.ott@suva.ch 


